\title{
Supporting information \\ High-throughput screening for the discovery of iron homeostasis modulators using an extremely sensitive fluorescent probe
}

Tasuku Hirayama*, Masato Niwa, Shusaku Hirosawa, Hideko Nagasawa

Laboratory of Pharmaceutical and Medicinal Chemistry, Gifu Pharmaceutical University, 1-25-4, Daigaku-Nishi, Gifu, 501-1196, Japan

E-mail: hirayamat@gifu-pu.ac.jp

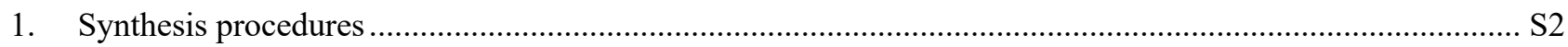

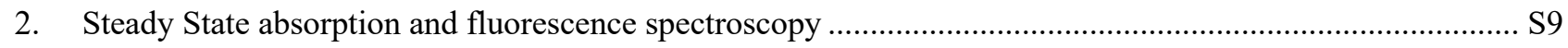

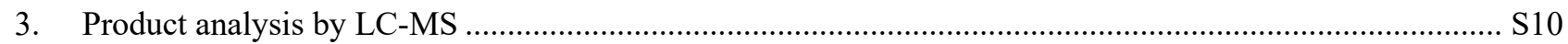

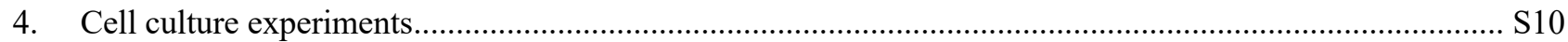

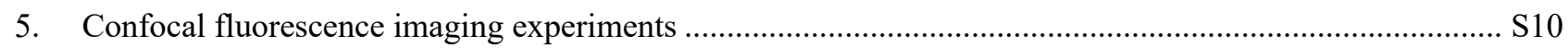

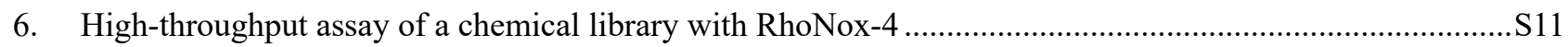

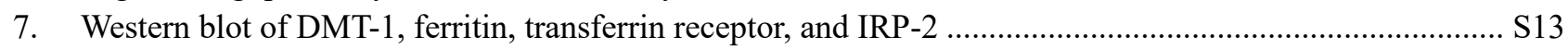

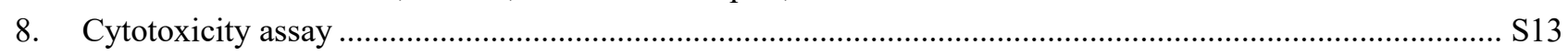

9. Quantification of total intracellular iron by atomic absorption spectrometry ............................................ S14

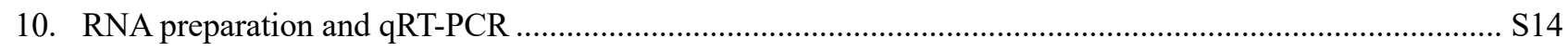

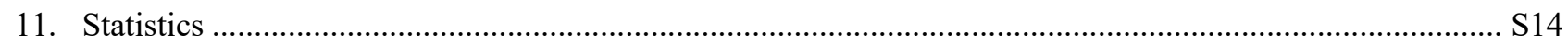

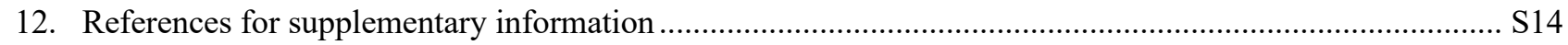

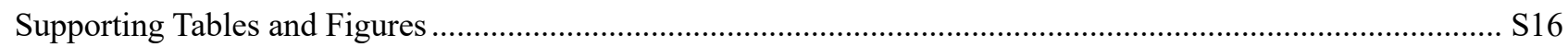

Table S1 and Table S2 Photophysical properties of RhoNox-N and Rhodamine-N .................................. S16

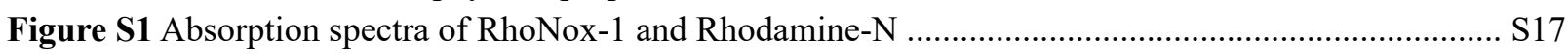

Figure S2 Fluorescence spectral changes of RhoNox-N upon the addition of $\mathrm{Fe}(\mathrm{II})$................................ S18

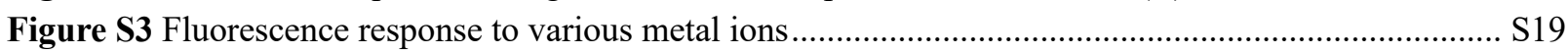

Figure S4 Fluorescence response to ROS, RSS, RNS, and reductants ................................................. S20

Figure S5-S11 LC-MS analysis of the reaction between the probes an Fe(II) .................................. S21-S24

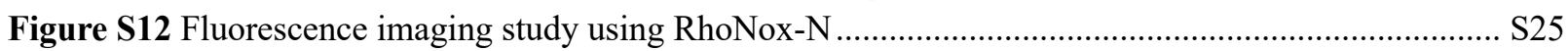

Figure S13 Fluorescence imaging study using RhoNox-N with Pluronic F-127 ....................................... S26

Figure S14 Fluorescence imaging study of dose-dependency of Fe(II) and a chelator ............................. S27

Figure S15 Fluorescence response of RhoNox-4 to various concentrations of $\mathrm{Fe}(\mathrm{II})$ in cuvettes ............... S27

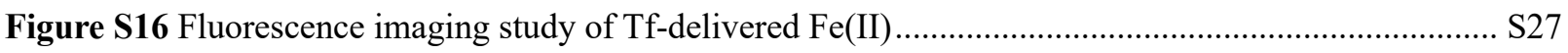

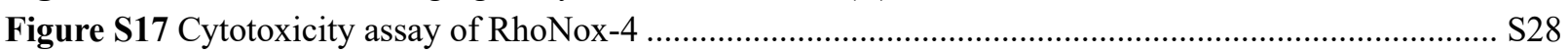

Figure S18 Co-localization assay ................................................................................................. S28

Figure S19 Fluorescence response of RhoNox-4 to $\mathrm{Fe}(\mathrm{II})$ at various $\mathrm{pH}$............................................... S29

Figure S20 Fluorescence imaging study for evaluation of FAC and DFO .......................................... S29

Figure S21 Microplate-based analysis of labile Fe(II) in living cells treated with FAC .............................. S30

Figure S22 Microplate-based analysis of labile Fe(II) in living cells treated with DFO .............................. S31

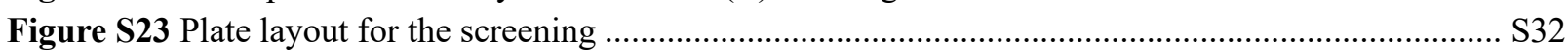

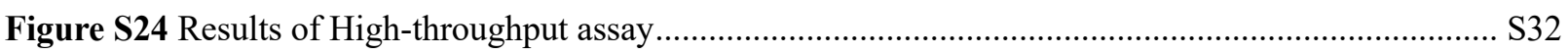

Figure S25 Effect of lomofungin on the fluorescence response of RhoNox-4 to Fe(II) in cuvettes............ S33

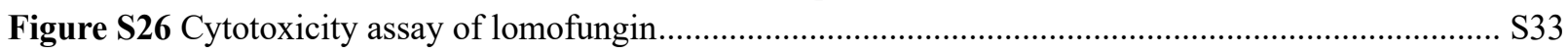

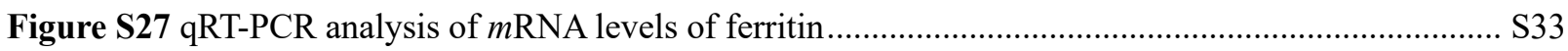

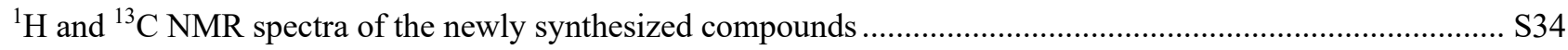




\section{Synthesis Procedures}

\section{General synthetic procedure}

All chemicals used in this study were commercial products of the highest available purity. ${ }^{1} \mathrm{H}$-NMR spectra were obtained on a JEOL ECA-500 spectrometer at $500 \mathrm{MHz}$ and JEOL JNM AL-400 spectrometer at $400 \mathrm{MHz} .{ }^{13} \mathrm{C}$ NMR spectra were obtained on a JEOL ECA-500 spectrometer at $125 \mathrm{MHz}$ and JEOL ECA-500 spectrometer at $100 \mathrm{MHz}$. Chemical shifts of ${ }^{1} \mathrm{H}-\mathrm{NMR}$ are referenced to TMS $(0.00)$ or $\mathrm{CD}_{3} \mathrm{OD}$ (3.31). Chemical shifts of ${ }^{13} \mathrm{C}$ NMR are referenced to $\mathrm{CDCl}_{3}$ (77.0) or $\mathrm{CD}_{3} \mathrm{OD}$ (49.0). Chemical shifts and coupling constants were recorded in units of ppm and Hz, respectively. ESI-mass spectra were measured on a JEOL JMS-T100TD mass spectrometer. High-resolution mass spectra (HRMS) were measured on a JEOL JMS-T100TD by using PEG as an internal standard. Reactions were monitored by silica gel TLC (Merck, Silica gel $60 \mathrm{~F}_{254}$ ) with visualization of components by UV light $(254 \mathrm{~nm})$ or with visual observation of the dye spots, and UV-Vis. Products were purified on a silica gel column chromatography (Taiko-shoji, AP-300S).

\section{Preparation of Rhodamine derivatives (Rhodamine-N: $\mathrm{N}=\mathbf{2 - 8}$ )}<smiles>CC(C)(C)OC(=O)N1CCN(c2ccc3c(c2)Oc2cc(N4CCN(C(=O)OC(C)(C)C)CC4)ccc2C32OC(=O)c3ccccc32)CC1</smiles>

Rhodamine-4
1. HCl/EtOAc, r.t.<smiles>[X]CC1(c2ccc3c(c2)Oc2cc(N4CCCCC4)ccc2C32OC(=O)c3ccccc32)CCCC1</smiles>

Rhodamine-5 (X=N-Ac): $92 \%$ Rhodamine-6 (X=N-COPy): $31 \%$ Rhodamine-7 (X=N-CO $\left.{ }_{2} \mathrm{Et}\right): 86 \%$ Rhodamine-8 (X=N-Piv): $91 \%$

Scheme S1. Synthetic routes of Rhodamine-N ( $=5-8)$. Rhodamine-2, Rhodamine-3, and Rhodamine-4 were synthesized and characterized as previously reported. ${ }^{1}$

\section{Rhodamine-5}<smiles>CC(C)N1CCN(c2ccc3c(c2)Oc2cc(N4CCN(C)CC4)ccc2C32OC(=O)c3ccccc32)CC1</smiles>

To a solution of Rhodamine- $4^{1}(40 \mathrm{mg}, 0.049 \mathrm{mmol})$ in $\mathrm{CH}_{2} \mathrm{Cl}_{2}(1 \mathrm{~mL})$ were added $\mathrm{Et}_{3} \mathrm{~N}(68 \mu \mathrm{L}, 0.49 \mathrm{mmol})$ and pyridine $(9.2 \mu \mathrm{L}, 0.11 \mathrm{mmol})$. After cooling to $0{ }^{\circ} \mathrm{C}$, acetyl chloride $(8.1 \mu \mathrm{L}, 0.11 \mathrm{mmol}$, dissolved in $0.5 \mathrm{~mL}$ $\mathrm{CH}_{2} \mathrm{Cl}_{2}$ ) was added dropwise to the reaction mixture and the resulting mixture was stirred at room temperature for $3 \mathrm{~h}$. The mixture was cooled to $0{ }^{\circ} \mathrm{C}$ and then the additional amount of pyridine $(9.2 \mu \mathrm{L}, 0.11 \mathrm{mmol})$ and acetyl chloride $\left(8.1 \mu \mathrm{L}, 0.11 \mathrm{mmol}\right.$, dissolved in $\left.0.5 \mathrm{~mL} \mathrm{CH}_{2} \mathrm{Cl}_{2}\right)$ were added dropwise to the mixture. After stirring at room temperature for $2 \mathrm{~h}$, the reaction mixture was quenched with saturated aq. $\mathrm{NaHCO}_{3}(10 \mathrm{~mL})$, which was 
extracted with $\mathrm{CH}_{2} \mathrm{Cl}_{2}(10 \mathrm{~mL} \times 3)$. The combined organic phases were washed with $\mathrm{H}_{2} \mathrm{O}(20 \mathrm{~mL})$ and brine $(20$ $\mathrm{mL}$ ), dried over anhydrous magnesium sulfate, and evaporated. The resulting purple solid was purified by silica gel column chromatography $\left(\mathrm{CHCl}_{3}: \mathrm{MeOH}=20: 1\right.$ to $\left.10: 1\right)$ to afford Rhodamine-5 as a purple solid (37 $\left.\mathrm{mg}, 92 \%\right)$. ${ }^{1} \mathrm{H}-\mathrm{NMR}\left(\mathrm{CDCl}_{3}, 500 \mathrm{MHz}\right) \delta: 8.02(\mathrm{~d}, J=7.4 \mathrm{~Hz}, 1 \mathrm{H}), 7.66(\mathrm{t}, J=7.4 \mathrm{~Hz}, 1 \mathrm{H}), 7.60(\mathrm{t}, J=7.4 \mathrm{~Hz}, 1 \mathrm{H}), 7.16(\mathrm{~d}$, $J=7.4 \mathrm{~Hz}, 1 \mathrm{H}), 6.69(\mathrm{~d}, J=2.9 \mathrm{~Hz}, 2 \mathrm{H}), 6.66(\mathrm{~d}, J=8.6 \mathrm{~Hz}, 2 \mathrm{H}), 6.60(\mathrm{dd}, J=8.6 \mathrm{~Hz}, 2.3 \mathrm{~Hz}, 2 \mathrm{H}), 3.84-3.71(\mathrm{~m}$, $4 \mathrm{H}), 3.63(\mathrm{t}, J=5.2 \mathrm{~Hz}, 4 \mathrm{H}), 3.31-3.19(\mathrm{~m}, 8 \mathrm{H}), 2.15(\mathrm{~s}, 6 \mathrm{H})$

${ }^{13}$ C-NMR $\left(\mathrm{CDCl}_{3}, 100 \mathrm{MHz}\right) \delta$ 169.5, 169.0, 153.0, 152.5, 152.4, 134.8, 129.6, 128.9, 127.0, 124.9, 123.9, 112.1, $110.0,102.4,48.5,48.1,45.8,41.0,21.3$.

HRMS (ESI+): $m / z$ calculated for $\mathrm{C}_{32} \mathrm{H}_{32} \mathrm{~N}_{4} \mathrm{NaO}_{5}{ }^{+}: 575.2265$, found 575.2288 .

\section{Rhodamine-6}<smiles>CCCCC(=O)N1CCN(c2ccc3c(c2)Oc2cc(N4CCN(C(=O)CCCC)CC4)ccc2C32OC(=O)c3ccccc32)CC1</smiles>

To a solution of Rhodamine- $4^{1}(89.5 \mathrm{mg}, 0.134 \mathrm{mmol})$ in EtOAc $(2 \mathrm{~mL})$ was added $4 \mathrm{M} \mathrm{HCl} / \mathrm{EtOAc}(2 \mathrm{~mL})$ dropwise at $0{ }^{\circ} \mathrm{C}$. After stirring at room temperature for $11 \mathrm{~h}$, the mixture was evaporated. To a solution of the resulting purple solid and picolinic acid $(35 \mathrm{mg}, 0.28 \mathrm{mmol})$ in dry DMF $(4 \mathrm{~mL})$ were added $\mathrm{Et}_{3} \mathrm{~N}(93 \mu \mathrm{L}, 0.67$ $\mathrm{mmol})$ and $\mathrm{EDC} \cdot \mathrm{HCl}(54 \mathrm{mg}, 0.281 \mathrm{mmol})$ at $0{ }^{\circ} \mathrm{C}$. After stirring for $3 \mathrm{~h}$ at room temperature, the additional amount of picolinic acid $(15 \mathrm{mg}, 0.121 \mathrm{mmol}), \mathrm{Et}_{3} \mathrm{~N}(19 \mu \mathrm{L}, 0.13 \mathrm{mmol})$, and $\mathrm{EDC} \cdot \mathrm{HCl}(23 \mathrm{mg}, 0.12 \mathrm{mmol})$ were added to the reaction mixture at $0{ }^{\circ} \mathrm{C}$. After stirring at room temperature for $18 \mathrm{~h}$, the reaction mixture was diluted with EtOAc $(40 \mathrm{~mL})$. The mixture was extracted with $\mathrm{H}_{2} \mathrm{O}(30 \mathrm{~mL} \times 2)$ and brine $(30 \mathrm{~mL})$. The organic layer was dried over anhydrous sodium sulfate and evaporated. The resulting pale yellow oil was purified by silica gel column chromatography $\left(\mathrm{CHCl}_{3}: \mathrm{MeOH}=50: 1\right.$ to $\left.20: 1\right)$ to afford Rhodamine- 6 as a pale purple solid $(29 \mathrm{mg}, 31 \%$ for 2 steps).

${ }^{1} \mathbf{H}-\mathbf{N M R}\left(\mathrm{CDCl}_{3}, 500 \mathrm{MHz}\right) \delta 8.61(\mathrm{~d}, J=4.6 \mathrm{~Hz}, 2 \mathrm{H}), 8.01(\mathrm{~d}, J=7.4 \mathrm{~Hz}, 1 \mathrm{H}), 7.83(\mathrm{td}, J=7.7,1.7 \mathrm{~Hz}, 2 \mathrm{H})$, $7.71(\mathrm{~d}, J=8.0 \mathrm{~Hz}, 2 \mathrm{H}), 7.69-7.63(\mathrm{~m}, 1 \mathrm{H}), 7.63-7.55(\mathrm{~m}, 1 \mathrm{H}), 7.45-7.31(\mathrm{~m}, 2 \mathrm{H}), 7.17(\mathrm{~d}, J=7.4 \mathrm{~Hz}, 1 \mathrm{H}), 6.70$ $(\mathrm{d}, J=2.3 \mathrm{~Hz}, 2 \mathrm{H}), 6.65(\mathrm{~d}, J=8.6 \mathrm{~Hz}, 2 \mathrm{H}), 6.60(\mathrm{dd}, J=9.2,2.3 \mathrm{~Hz}, 2 \mathrm{H}), 4.09-3.88(\mathrm{~m}, 4 \mathrm{H}), 3.88-3.73(\mathrm{~m}, 4 \mathrm{H})$, $3.50-3.32(\mathrm{~m}, 4 \mathrm{H}), 3.32-3.14(\mathrm{~m}, 4 \mathrm{H})$

${ }^{13} \mathbf{C}-\mathrm{NMR}\left(\mathrm{CDCl}_{3}, 125 \mathrm{MHz}\right) \delta$ 169.6, 167.4, 153.6, 153.1, 152.5, 148.2, 137.2, 134.8, 129.5, 128.9, 126.9, 124.9, 124.7, 124.2, 123.9, 112.1, 109.9, 102.4, 83.6, 48.8, 48.2, 46.7, 42.1.

HRMS (ESI+): $m / z$ calculated for $\mathrm{C}_{40} \mathrm{H}_{35} \mathrm{~N}_{6} \mathrm{O}_{5}{ }^{+}: 679.2663$, found: 679.2692 . 


\section{Rhodamine-7}<smiles>CCOC(=O)N1CCN(c2ccc3c(c2)Oc2cc(N4CCN(C(=O)OCC)CC4)ccc2C32OC(=O)c3ccccc32)CC1</smiles>

To a solution of Rhodamine- $4{ }^{1}(100 \mathrm{mg}, 0.15 \mathrm{mmol})$ in EtOAc $(3 \mathrm{~mL})$ was added $4 \mathrm{M} \mathrm{HCl} / \mathrm{EtOAc}(3 \mathrm{~mL})$ at $0{ }^{\circ} \mathrm{C}$. After stirring at room temperature for $6 \mathrm{~h}$, hexane was added to the reaction mixture, and the resulting purple precipitate was collected by the filtration. The precipitate was then dissolved in $\mathrm{MeOH}$. After removal of the solvent by the evaporation, the resulting purple solid was dissolved with $\mathrm{CH}_{2} \mathrm{Cl}_{2}(5 \mathrm{~mL})$. Then, $\mathrm{Et}_{3} \mathrm{~N}(84 \mu \mathrm{L}, 0.60 \mathrm{mmol})$ and ethyl chloroformate ( $32 \mu \mathrm{L}, 0.33 \mathrm{mmol}$ ) were added to the mixture at $0{ }^{\circ} \mathrm{C}$. After stirring at room temperature for $16 \mathrm{~h}$, the reaction solvent was removed by evaporation. The residue was purified by silica gel column chromatography (EtOAc : hexane $=1: 2$ to $2: 1$ ) to afford Rhodamine-7 as purple oil (79 $\mathrm{mg}, 86 \%$ ).

${ }^{1}$ H-NMR $\left(\mathrm{CDCl}_{3}, 400 \mathrm{MHz}\right) \delta 8.01(\mathrm{~d}, J=7.2 \mathrm{~Hz}, 1 \mathrm{H}), 7.87-7.39(\mathrm{~m}, 2 \mathrm{H}), 7.16(\mathrm{~d}, J=7.7 \mathrm{~Hz}, 1 \mathrm{H}), 6.69(\mathrm{~d}, J=$ $1.9 \mathrm{~Hz}, 2 \mathrm{H}), 6.65$ (d, $J=8.7 \mathrm{~Hz}, 2 \mathrm{H}), 6.59$ (dd, $J=8.7,2.4 \mathrm{~Hz}, 2 \mathrm{H}), 4.17$ (q, $J=7.2 \mathrm{~Hz}, 4 \mathrm{H}), 3.62$ (t, $J=4.8 \mathrm{~Hz}$, $8 \mathrm{H}), 3.35-2.96(\mathrm{~m}, 8 \mathrm{H}), 1.28(\mathrm{t}, J=7.2 \mathrm{~Hz}, 6 \mathrm{H})$.

${ }^{13}$ C-NMR $\left(\mathrm{CDCl}_{3}, 100 \mathrm{MHz}\right) \delta 169.5,155.4,153.1,152.6,152.5,134.8,129.5,128.8,127.0,124.8,123.8,112.1$, $109.8,102.4,83.6,61.5,48.2,43.2,14.6$.

HRMS (ESI+): $m / z$ calculated for $\mathrm{C}_{34} \mathrm{H}_{37} \mathrm{~N}_{4} \mathrm{O}_{7}^{+}: 613.2657$, found: 613.2667 .

\section{Rhodamine-8}<smiles>CC(C)N1CCN(c2ccc3c(c2)Oc2cc(N4CCN(C(C)C)CC4)ccc2C32OC(=O)c3ccccc32)CC1</smiles>

To a solution of Rhodamine- $4^{1}(100 \mathrm{mg}, 0.15 \mathrm{mmol})$ in EtOAc $(3 \mathrm{~mL})$ was added $4 \mathrm{M} \mathrm{HCl} / \mathrm{EtOAc}(3 \mathrm{~mL})$ at $0{ }^{\circ} \mathrm{C}$. After stirring at room temperature for $6 \mathrm{~h}$, hexane was added to the reaction mixture, and the resulting purple precipitate was collected by filtration. The precipitate was then dissolved in $\mathrm{MeOH}$, and the solvent was evaporated. The resulting purple solid was dissolved with $\mathrm{CH}_{2} \mathrm{Cl}_{2}(5 \mathrm{~mL})$, and $\mathrm{Et}_{3} \mathrm{~N}(84 \mu \mathrm{L}, 0.600 \mathrm{mmol})$ and $\mathrm{Piv}_{2} \mathrm{O}(67 \mu \mathrm{L}$, $0.330 \mathrm{mmol}$ ) were added to the mixture at $0{ }^{\circ} \mathrm{C}$. After stirring at room temperature for $2 \mathrm{~h}$, the reaction solvent was removed by evaporation. The residue was purified by silica gel column chromatography (EtOAc $:$ hexane $=1: 2$ to $3: 1)$ to afford Rhodamine- 8 as purple oil ( $87 \mathrm{mg}, 91 \%)$.

${ }^{1} \mathbf{H}-\mathbf{N M R}\left(\mathrm{CDCl}_{3}, 400 \mathrm{MHz}\right) \delta 8.01(\mathrm{~d}, J=7.7 \mathrm{~Hz}, 1 \mathrm{H}), 7.63(\mathrm{dt}, J=19.2,7.4 \mathrm{~Hz}, 2 \mathrm{H}), 7.15(\mathrm{~d}, J=7.2 \mathrm{~Hz}, 1 \mathrm{H})$, $6.68(\mathrm{~d}, J=2.4 \mathrm{~Hz}, 2 \mathrm{H}), 6.65(\mathrm{~d}, J=8.7 \mathrm{~Hz}, 2 \mathrm{H}), 6.58(\mathrm{dd}, J=8.7,2.4 \mathrm{~Hz}, 2 \mathrm{H}), 3.80(\mathrm{t}, J=4.8 \mathrm{~Hz}, 8 \mathrm{H}), 3.22(\mathrm{t}, J$ $=5.1 \mathrm{~Hz}, 8 \mathrm{H}), 1.36(\mathrm{~s}, 18 \mathrm{H})$ 
${ }^{13}$ C-NMR $\left(\mathrm{CDCl}_{3}, 100 \mathrm{MHz}\right) \delta 176.4,169.5,153.0,152.5,152.4,134.8,129.5,128.7,126.9,124.8,123.8,111.8$, $109.8,102.2,83.6,48.3,44.6,38.6,28.3$

HRMS (ESI+): $m / z$ calculated for $\mathrm{C}_{38} \mathrm{H}_{45} \mathrm{~N}_{4} \mathrm{O}_{5}{ }^{+}: 637.3384$, found: 637.3389 .

\section{Preparation of RhoNox-N (N=2-8)}<smiles></smiles>

Rhodamine-N
$\underset{m-\mathrm{CPBA}, \mathrm{NaHCO}_{3}}{\longrightarrow}$

EtOAc, r.t., $1 \mathrm{~h}$

\begin{tabular}{lll}
\hline $\mathrm{N}$ & $\mathrm{X}$ & yield \\
\hline 2 & $\mathrm{CH}_{2}$ & $15 \%$ \\
3 & $\mathrm{O}$ & $32 \%$ \\
4 & $\mathrm{~N}-\mathrm{Boc}$ & $54 \%$ \\
5 & $\mathrm{~N}-\mathrm{Ac}$ & $44 \%$ \\
6 & $\mathrm{~N}-\mathrm{COPy}_{2}$ & $26 \%$ \\
7 & $\mathrm{~N}-\mathrm{CO}_{2} \mathrm{Et}$ & $54 \%$ \\
8 & $\mathrm{~N}-P i v$ & $60 \%$ \\
\hline
\end{tabular}<smiles></smiles>

RhoNox-N

Scheme S2. Synthesis of RhoNox-2 - RhoNox-8

\section{RhoNox-2}<smiles>O=C1OC2(c3ccc(N4CCCCC4)cc3Oc3cc([N+]4([O-])CCCCC4)ccc32)c2ccccc21</smiles>

To a solution of Rhodamine- $2^{1}(78 \mathrm{mg}, 0.17 \mathrm{mmol})$ in EtOAc $(4 \mathrm{~mL})$ was added $m$-CPBA $(53 \mathrm{mg}, 0.18 \mathrm{mmol})$ at $0{ }^{\circ} \mathrm{C}$. After stirring at room temperature for $30 \mathrm{~min}$, the reaction solvent was removed by evaporation. The residue was purified by silica gel column chromatography $\left(\mathrm{CHCl}_{3}: \mathrm{MeOH}=100: 1\right.$ to $\left.20: 1\right)$ to afford RhoNox-2 as colorless solid (12 mg, 15\%).

${ }^{1} \mathbf{H}-\mathbf{N M R}\left(\mathrm{CD}_{3} \mathrm{OD}, 500 \mathrm{MHz}\right) \delta: 8.10(\mathrm{~d}, J=2.3 \mathrm{~Hz}, 1 \mathrm{H}), 8.04(\mathrm{~d}, J=8.0 \mathrm{~Hz}, 1 \mathrm{H}), 7.78(\mathrm{t}, J=7.2 \mathrm{~Hz}, 1 \mathrm{H}), 7.72(\mathrm{t}$, $J=7.2 \mathrm{~Hz}, 1 \mathrm{H}), 7.63(\mathrm{dd}, J=8.9,2.6 \mathrm{~Hz}, 1 \mathrm{H}), 7.20(\mathrm{~d}, J=8.0 \mathrm{~Hz}, 1 \mathrm{H}), 6.95(\mathrm{~d}, J=8.6 \mathrm{~Hz}, 1 \mathrm{H}), 6.81(\mathrm{~d}, J=2.3$ $\mathrm{Hz}, 1 \mathrm{H}), 6.74(\mathrm{dd}, J=8.9,2.6 \mathrm{~Hz}, 1 \mathrm{H}), 6.61(\mathrm{~d}, J=9.2 \mathrm{~Hz}, 1 \mathrm{H}), 4.00-3.83(\mathrm{~m}, 2 \mathrm{H}), 3.30-3.20(\mathrm{~m}, 6 \mathrm{H}), 2.56-2.36$ (m, 2H), 1.91-1.53 (m, 10H).

${ }^{13}$ C-NMR $\left(\mathrm{CD}_{3} \mathrm{OD}, 125 \mathrm{MHz}\right) \delta: 169.8,156.3,153.9,152.9,152.3,151.9,135.5,130.1,129.0,128.2,126.4,124.7$, 123.8, 120.4, 115.3, 112.6, 109.9, 107.1, 101.3, 82.8, 68.1, 68.1, 25.2, 24.1, 20.9, 20.9.

HRMS (ESI+): $m / z$ calculated for $\mathrm{C}_{30} \mathrm{H}_{31} \mathrm{~N}_{2} \mathrm{O}_{4}{ }^{+}: 483.2270$, found: 483.2291 . 


\section{RhoNox-3}<smiles>O=C1OC2(c3ccc(N4CCOCC4)cc3Oc3cc([N+]4([O-])CCOCC4)ccc32)c2ccccc21</smiles>

To a solution of Rhodamine- $3^{1}(109 \mathrm{mg}, 0.22 \mathrm{mmol})$ in EtOAc $(5 \mathrm{~mL})$ was added $m$-CPBA (70 mg, $\left.0.24 \mathrm{mmol}\right)$ at $0{ }^{\circ} \mathrm{C}$. After stirring at room temperature for $30 \mathrm{~min}$, the reaction solvent was removed by evaporation. The residue was purified by silica gel column chromatography $\left(\mathrm{CHCl}_{3}: \mathrm{MeOH}=100: 1\right.$ to $\left.10: 1\right)$ to afford RhoNox-3 as colorless solid (36 mg, 32\%).

${ }^{1} \mathrm{H}-\mathrm{NMR}\left(\mathrm{CD}_{3} \mathrm{OD}, 500 \mathrm{MHz}\right) \delta: 8.11(\mathrm{~d}, J=2.3 \mathrm{~Hz}, 1 \mathrm{H}), 8.04(\mathrm{~d}, J=7.4 \mathrm{~Hz}, 1 \mathrm{H}), 7.76(\mathrm{td}, J=7.6,1.3 \mathrm{~Hz}, 1 \mathrm{H})$, $7.72(\mathrm{td}, J=7.4,1.1 \mathrm{~Hz}, 1 \mathrm{H}), 7.65(\mathrm{dd}, J=8.9,2.6 \mathrm{~Hz}, 1 \mathrm{H}), 7.18(\mathrm{~d}, J=7.4 \mathrm{~Hz}, 1 \mathrm{H}), 6.99(\mathrm{~d}, J=8.6 \mathrm{~Hz}, 1 \mathrm{H}), 6.84$ $(\mathrm{d}, J=2.9 \mathrm{~Hz}, 1 \mathrm{H}), 6.74(\mathrm{dd}, J=8.8,2.7 \mathrm{~Hz}, 1 \mathrm{H}), 6.65(\mathrm{~d}, J=9.2 \mathrm{~Hz}, 1 \mathrm{H}), 4.45(\mathrm{t}, J=11.5 \mathrm{~Hz}, 2 \mathrm{H}), 4.20-4.04(\mathrm{~m}$, 2H), 4.00-3.85 (m, 2H), 3.79 (t, $J=4.9 \mathrm{~Hz}, 4 \mathrm{H}), 3.27-3.12(\mathrm{~m}, 6 \mathrm{H})$.

${ }^{13} \mathbf{C}-\mathrm{NMR}\left(\mathrm{CD}_{3} \mathrm{OD}, 125 \mathrm{MHz}\right) \delta: 169.7,155.6,153.6,152.9,152.1,151.9,135.5,130.2,129.3,128.3,126.3,124.8$, $123.8,120.7,115.3,112.0,109.9,108.3,101.2,82.4,66.9,66.9,66.4,61.6,47.9$.

HRMS (ESI+): $m / z$ calculated for $\mathrm{C}_{28} \mathrm{H}_{27} \mathrm{~N}_{2} \mathrm{O}_{6}{ }^{+}: 487.1869$, found: 487.1897 .

\section{RhoNox-4}<smiles>CC(C)(C)OC(=O)N1CCN(c2ccc3c(c2)Oc2cc([N+]4([O-])CCN(C(C)(C)C)CC4)ccc2C32OC(=O)c3ccccc32)CC1</smiles>

To a solution of Rhodamine-4 ${ }^{1}(114 \mathrm{mg}, 0.17 \mathrm{mmol})$ in EtOAc $(5 \mathrm{~mL})$ was added $m$-CPBA ( $\left.46 \mathrm{mg}, 0.19 \mathrm{mmol}\right)$ at $0{ }^{\circ} \mathrm{C}$. After stirring at room temperature for $30 \mathrm{~min}$, the reaction solvent was removed by evaporation. The residue was purified by silica gel column chromatography $\left(\mathrm{CHCl}_{3}: \mathrm{MeOH}=100: 1\right.$ to $\left.30: 1\right)$ to afford RhoNox-4 as white powder (63 mg, 54\%).

${ }^{1} \mathrm{H}-\mathrm{NMR}\left(\mathrm{CD}_{3} \mathrm{OD}, 500 \mathrm{MHz}\right) \delta: 8.12(\mathrm{~d}, J=2.3 \mathrm{~Hz}, 1 \mathrm{H}), 8.04(\mathrm{~d}, J=7.4 \mathrm{~Hz}, 1 \mathrm{H}), 7.82-7.74(\mathrm{~m}, 1 \mathrm{H}), 7.74-7.68$ $(\mathrm{m}, J=7.4 \mathrm{~Hz}, 1 \mathrm{H}), 7.65(\mathrm{dd}, J=8.9,2.6 \mathrm{~Hz}, 1 \mathrm{H}), 7.18(\mathrm{~d}, J=7.4 \mathrm{~Hz}, 1 \mathrm{H}), 6.97(\mathrm{~d}, J=9.2 \mathrm{~Hz}, 1 \mathrm{H}), 6.86(\mathrm{~d}, J=$ $2.3 \mathrm{~Hz}, 1 \mathrm{H}), 6.76(\mathrm{dd}, J=9.2,2.3 \mathrm{~Hz}, 1 \mathrm{H}), 6.65$ (d, $J=8.6 \mathrm{~Hz}, 1 \mathrm{H}), 4.27-4.08(\mathrm{~m}, 2 \mathrm{H}), 4.08-3.94(\mathrm{~m}, 2 \mathrm{H}), 3.94-$ 3.67 (m, 2H), 3.67-3.44 (m, 4H), $3.24(\mathrm{t}, J=5.2 \mathrm{~Hz}, 6 \mathrm{H}), 1.49$ (s, 9H), 1.48 (s, 9H).

${ }^{13}$ C-NMR $\left(\mathrm{CD}_{3} \mathrm{OD}, 125 \mathrm{MHz}\right) \delta: 170.9,156.8,156.3,155.6,154.6,154.1,153.4,153.1,136.8,131.5,130.6,129.7$, 127.6, 126.1, 125.1, 122.0, 116.7, 114.0, 111.3, 109.6, 103.1, 83.6, 82.1, 81.4, 67.9, 45.0 (br), 43.9 (br), 40.4 (br), 39.2 (br), 28.7, 28.6.

HRMS (ESI+): $m / z$ calculated for $\left[\mathrm{C}_{38} \mathrm{H}_{44} \mathrm{~N}_{4} \mathrm{NaO}_{8}\right]^{+}: 707.3051$, found: 707.3028 . 


\section{RhoNox-5}<smiles>CC(C)N1CCN(c2ccc3c(c2)Oc2cc(N4CCN(C)CC4)ccc2C32OC(=O)c3ccccc32)CC1</smiles>

To a solution of Rhodamine-5 (133 mg, $0.24 \mathrm{mmol})$ in EtOAc $(4 \mathrm{~mL})$ and $\mathrm{CH}_{2} \mathrm{Cl}_{2}(2 \mathrm{~mL})$ was slowly added $m$ chloroperbenzoic acid $(46 \mathrm{mg}, 0.265 \mathrm{mmol})$ at $0{ }^{\circ} \mathrm{C}$. The mixture was warmed to room temperature and stirred for $1 \mathrm{~h}$. The reaction mixture was evaporated, and then the residue was purified by silica gel column chromatography $\left(\mathrm{CHCl}_{3}: \mathrm{MeOH}=20: 1\right.$ to $\left.8: 1\right)$ to afford RhoNox-5 as a white powder $(60 \mathrm{mg}, 44 \%)$.

${ }^{1} \mathbf{H}-\mathbf{N M R}\left(\mathrm{CD}_{3} \mathrm{OD}, 500 \mathrm{MHz}\right) \delta: 8.13(\mathrm{q}, J=2.3 \mathrm{~Hz}, 1 \mathrm{H}), 8.05(\mathrm{~d}, J=7.4 \mathrm{~Hz}, 1 \mathrm{H}), 7.86-7.76(\mathrm{~m}, 1 \mathrm{H}), 7.74(\mathrm{t}, J=$ $7.2 \mathrm{~Hz}, 1 \mathrm{H}), 7.70-7.58(\mathrm{~m}, 1 \mathrm{H}), 7.20(\mathrm{~d}, J=7.4 \mathrm{~Hz}, 1 \mathrm{H}), 7.00(\mathrm{~d}, J=9.2 \mathrm{~Hz}, 1 \mathrm{H}), 6.88(\mathrm{~d}, J=2.3 \mathrm{~Hz}, 1 \mathrm{H}), 6.79$ $(\mathrm{dd}, J=8.6,2.3 \mathrm{~Hz}, 1 \mathrm{H}), 6.68(\mathrm{~d}, J=9.2 \mathrm{~Hz}, 1 \mathrm{H}), 4.64(\mathrm{~d}, J=14.3 \mathrm{~Hz}, 1 \mathrm{H}), 4.23-4.08(\mathrm{~m}, 2 \mathrm{H}), 4.08-3.92(\mathrm{~m}$, 2H), 3.77-3.61 (m, 5H), 3.38-3.32 (m, 2H), 3.30-3.21 (m, 4H), $2.20(\mathrm{~s}, 3 \mathrm{H}), 2.15(\mathrm{~s}, 3 \mathrm{H})$.

${ }^{13}$ C-NMR $\left(\mathrm{CD}_{3} \mathrm{OD}, 125 \mathrm{MHz}\right) \delta: 171.8,171.8,171.0,156.6,154.5,154.1,153.4,153.2,136.8,131.5,130.7$, 129.7, 127.6, 126.1, 125.1, 122.2, 116.6, 113.9, 111.3, 109.7, 103.1, 83.6, 68.0, 47.0, 42.4, 42.3, 37.6, 21.1, 21.1.

HRMS (ESI+): $m / z$ calculated for $\left[\mathrm{C}_{32} \mathrm{H}_{33} \mathrm{~N}_{4} \mathrm{O}_{6}\right]^{+}: 569.2395$, found: 569.2387 .

\section{RhoNox-6}<smiles>CC(C)C(=O)N1CCN(c2ccc3c(c2)Oc2cc(N4CCN(C(=O)C(=O)N5CCCCC5)CC4)ccc2C32OC(=O)c3ccccc32)CC1</smiles>

To a solution of Rhodamine-6 (26 mg, $0.039 \mathrm{mmol})$ in EtOAc $(2 \mathrm{~mL})$ was slowly added $\mathrm{NaHCO}_{3}(3.6 \mathrm{mg}, 0.043$ mmol) and $m$-CPBA $(7.4 \mathrm{mg}, 0.043 \mathrm{mmol})$ at $0{ }^{\circ} \mathrm{C}$. After stirring at room temperature for $0.5 \mathrm{~h}$, the additional amount of $\mathrm{NaHCO}_{3}(0.3 \mathrm{mg}, 0.0039 \mathrm{mmol})$ and $m-\mathrm{CPBA}(0.7 \mathrm{mg}, 0.0039 \mathrm{mmol})$ was added to the reaction mixture at $0{ }^{\circ} \mathrm{C}$. After stirring at room temperature for $0.5 \mathrm{~h}$, the reaction mixture was evaporated, and then the residue was purified by silica gel column chromatography $\left(\mathrm{CHCl}_{3}: \mathrm{MeOH}=50: 1\right.$ to $\left.8: 1\right)$ to afford RhoNox-6 as a colorless solid (6.9 mg, $0.010 \mathrm{mmol}, 26 \%)$.

${ }^{1} \mathrm{H}-\mathrm{NMR}\left(\mathrm{CD}_{3} \mathrm{OD}, 500 \mathrm{MHz}\right) \delta 8.62(\mathrm{~s}, 2 \mathrm{H}), 8.16(\mathrm{~s}, 1 \mathrm{H}), 8.05(\mathrm{~d}, J=8.0 \mathrm{~Hz}, 1 \mathrm{H}), 8.03-7.99$ (m, $\left.1 \mathrm{H}\right), 7.98(\mathrm{dd}, J$ $=7.7,1.4 \mathrm{~Hz}, 1 \mathrm{H}), 7.79(\mathrm{t}, J=7.4 \mathrm{~Hz}, 1 \mathrm{H}), 7.75(\mathrm{~d}, J=7.4 \mathrm{~Hz}, 2 \mathrm{H}), 7.71(\mathrm{dd}, J=9.2,3.4 \mathrm{~Hz}, 1 \mathrm{H}), 7.66(\mathrm{~d}, J=8.0$ $\mathrm{Hz}, 1 \mathrm{H}), 7.59-7.43(2 \mathrm{H}), 7.21(\mathrm{~d}, J=7.4 \mathrm{~Hz}, 1 \mathrm{H}), 7.02(\mathrm{~d}, J=8.6 \mathrm{~Hz}, 1 \mathrm{H}), 6.92(\mathrm{~d}, J=2.9 \mathrm{~Hz}, 1 \mathrm{H}), 6.81(\mathrm{dd}, J=$ 8.9, 2.6 Hz, 1H), $6.69(\mathrm{~d}, J=9.2 \mathrm{~Hz}, 1 \mathrm{H}), 4.85-4.68(\mathrm{~m}, 1 \mathrm{H}), 4.25-4.11(\mathrm{~m}, 3 \mathrm{H}), 4.11-4.00(\mathrm{~m}, 1 \mathrm{H}), 4.00-3.83(\mathrm{~m}$, $3 \mathrm{H}), 3.64(\mathrm{t}, J=4.9 \mathrm{~Hz}, 2 \mathrm{H}), 3.52-3.36(\mathrm{~m}, 2 \mathrm{H}), 3.20(\mathrm{t}, J=8.6 \mathrm{~Hz}, 1 \mathrm{H})$.

${ }^{13}$ C-NMR $\left(\mathrm{CD}_{3} \mathrm{OD}, 125 \mathrm{MHz}\right) \delta 171.0,169.4,169.1,156.7,154.7,154.5,154.2,154.0,153.5,153.2,149.8,149.7$, 
$139.3,139.2,136.9,131.5,130.7,129.8,127.6,126.7,126.4,126.1,125.2,125.1,124.7,122.2,116.7,114.0,111.3$, 109.9, 103.3, 83.6, 68.2, 68.0, 47.9, 43.4, 43.1, 38.6.

HRMS (ESI+): $m / z$ calculated for $\mathrm{C}_{40} \mathrm{H}_{35} \mathrm{~N}_{6} \mathrm{O}_{6}{ }^{+}: 695.2613$, found: 695.2615 .

\section{RhoNox-7}<smiles>CCOC(=O)N1CCN(c2ccc3c(c2)Oc2cc([N+]4([O-])CCN(C(=O)OCC)CC4)ccc2C32OC(=O)c3ccccc32)CC1</smiles>

To a solution of Rhodamine-7 (77 mg, $0.13 \mathrm{mmol})$ in EtOAc (4 mL) was slowly added $m$-CPBA (34 mg, 0.14 $\mathrm{mmol}$ ) at $0{ }^{\circ} \mathrm{C}$. After stirring at room temperature for $1 \mathrm{~h}$, the reaction mixture was evaporated, and then the residue was purified by silica gel column chromatography $\left(\mathrm{CHCl}_{3}: \mathrm{MeOH}=1: 0\right.$ to $\left.100: 1\right)$ to afford RhoNox-7 as a pale purple solid (42 $\mathrm{mg}, 0.067 \mathrm{mmol}, 54 \%)$.

${ }^{1}$ H-NMR $\left(\mathrm{CD}_{3} \mathrm{OD}, 500 \mathrm{MHz}\right) \delta 8.10(\mathrm{~d}, J=2.3 \mathrm{~Hz}, 1 \mathrm{H}), 8.02(\mathrm{~d}, J=7.4 \mathrm{~Hz}, 1 \mathrm{H}), 7.81-7.72(\mathrm{~m}, 1 \mathrm{H}), 7.72-7.67$ (m, 1H), $7.63(\mathrm{dd}, J=8.9,2.6 \mathrm{~Hz}, 1 \mathrm{H}), 7.17(\mathrm{~d}, J=7.4 \mathrm{~Hz}, 1 \mathrm{H}), 6.96(\mathrm{~d}, J=9.2 \mathrm{~Hz}, 1 \mathrm{H}), 6.84(\mathrm{~d}, J=2.3 \mathrm{~Hz}$, $1 \mathrm{H}), 6.75(\mathrm{dd}, \mathrm{J}=8.9,2.6 \mathrm{~Hz}, 1 \mathrm{H}), 6.64(\mathrm{~d}, J=9.2 \mathrm{~Hz}, 1 \mathrm{H}), 4.29-4.08(\mathrm{~m}, 6 \mathrm{H}), 4.08-3.95(\mathrm{~m}, 2 \mathrm{H}), 3.84(\mathrm{~s}, 2 \mathrm{H})$, $3.58(\mathrm{~s}, 4 \mathrm{H}), 3.27-3.12(\mathrm{~m}, 6 \mathrm{H}), 1.35-1.19(\mathrm{~m}, 6 \mathrm{H})$.

${ }^{13}$ C-NMR $\left(\mathrm{CD}_{3} \mathrm{OD}, 125 \mathrm{MHz}\right) \delta 170.9,157.1,156.8,156.6,154.6,154.1,153.4,153.1,136.8,131.5,130.6$, 129.7, 127.6, 126.1, 125.1, 122.1, 116.7, 114.0, 111.3, 109.7, 103.2, 83.6, 67.8, 67.8, 63.3, 62.9, 44.5 (br), 39.7 (br), 15.0, 14.9.

HRMS (ESI+): $m / z$ calculated for $\mathrm{C}_{34} \mathrm{H}_{37} \mathrm{~N}_{4} \mathrm{O}_{8}{ }^{+}: 629.2606$, found: 629.2624 .

\section{RhoNox-8}<smiles>CC(C)N1CCN(c2ccc3c(c2)Oc2cc([N+]4([O-])CCN(c5ccccc5)CC4)ccc2C32OC(=O)c3ccccc32)CC1</smiles>

To a solution of Rhodamine- 8 ( $85 \mathrm{mg}, 0.13 \mathrm{mmol})$ in EtOAc ( $4 \mathrm{~mL})$ was slowly added $m$-CPBA (36 mg, 0.15 $\mathrm{mmol}$ ) at $0{ }^{\circ} \mathrm{C}$. After stirring at room temperature for $1 \mathrm{~h}$, the reaction mixture was evaporated, and then the residue was purified by silica gel column chromatography $\left(\mathrm{CHCl}_{3}: \mathrm{MeOH}=1: 0\right.$ to $\left.15: 1\right)$ to afford RhoNox-8 as a pale purple solid (52 $\mathrm{mg}, 0.080 \mathrm{mmol}, 60 \%$ ).

${ }^{1}$ H-NMR $\left(\mathrm{CD}_{3} \mathrm{OD}, 500 \mathrm{MHz}\right) \delta 8.13(\mathrm{~d}, J=2.3 \mathrm{~Hz}, 1 \mathrm{H}), 8.03$ (d, $\left.J=7.4 \mathrm{~Hz}, 1 \mathrm{H}\right), 7.89$ (s, 1H), 7.77 (td, $J=7.4$, $1.1 \mathrm{~Hz}, 1 \mathrm{H}), 7.72(\mathrm{t}, J=7.2 \mathrm{~Hz}, 1 \mathrm{H}), 7.65(\mathrm{dd}, J=8.9,2.6 \mathrm{~Hz}, 1 \mathrm{H}), 7.19(\mathrm{~d}, J=7.4 \mathrm{~Hz}, 1 \mathrm{H}), 6.98(\mathrm{~d}, J=8.6 \mathrm{~Hz}$, 
$1 \mathrm{H}), 6.87(\mathrm{~d}, J=2.3 \mathrm{~Hz}, 1 \mathrm{H}), 6.78(\mathrm{dd}, J=8.9,2.6 \mathrm{~Hz}, 1 \mathrm{H}), 6.66(\mathrm{~d}, J=8.6 \mathrm{~Hz}, 1 \mathrm{H}), 4.52(\mathrm{~d}, J=13.7 \mathrm{~Hz}, 2 \mathrm{H})$, 4.08-3.95 (m, 2H), 3.95-3.84 (m, 2H), 3.79 (t, $J=5.2 \mathrm{~Hz}, 4 \mathrm{H}), 1.31$ (s, 9H), 1.29 (s, 9H).

${ }^{13} \mathrm{C}-\mathrm{NMR}\left(\mathrm{CD}_{3} \mathrm{OD}, 125 \mathrm{MHz}\right) \delta$ 178.6, 178.5, 170.9, 156.6, 154.5, 154.1, 153.4, 153.1, 136.9, 131.5, 130.6,

129.7, 127.6, 126.1, 125.1, 122.1, 116.7, 113.8, 111.4, 109.7, 102.9, 83.6, 68.2, 68.1, 46.0, 41.3, 41.3, 41.2, 39.7, 28.7, 28.5.

HRMS (ESI+): $m / z$ calculated for $\mathrm{C}_{38} \mathrm{H}_{45} \mathrm{~N}_{4} \mathrm{O}_{6}{ }^{+}: 653.3334$, found: 653.3325 .

\section{Steady-state absorption and fluorescence spectroscopy}

The UV-vis absorption spectra were recorded on an Agilent8453 photodiode array UV-vis spectrometer. Fluorescence spectra were recorded using a JASCO FP6600 with a slit width of $5 \mathrm{~nm}$ and $6 \mathrm{~nm}$ for excitation and emission, respectively. The path length was $1 \mathrm{~cm}$ with a cell volume of $3.0 \mathrm{~mL}$. For all the fluorescence measurements, probes were used at a final concentration of $2 \mu \mathrm{M}$ (from $1 \mathrm{mM}$ stock solution in DMSO) in $50 \mathrm{mM}$ HEPES buffer ( $\mathrm{pH} 7.4$ ).

Quantum yields were measured in $50 \mathrm{mM}$ HEPES buffer ( $\mathrm{pH} 7.4,0.2 \% \mathrm{DMSO}$ as co-solvent) by using a Quantaurus-QY absolute photo-luminescence quantum yields measurement system (C11347-01, Hamamatsu Photonics).

\section{Evaluation of the probes by fluorescence spectroscopy}

Fluorescence responses of each probe to various metal ions were measured as follows. An aqueous solution of transition metal ion species (stock solutions: $10 \mathrm{mM}$ for $\mathrm{MnSO}_{4}, \mathrm{CoSO}_{4}, \mathrm{NiSO}_{4}, \mathrm{FeSO}_{4}, \mathrm{FeCl}_{3}, \mathrm{CuSO}_{4}$, and $\mathrm{ZnSO}_{4}$; $1 \mathrm{M}$ for $\mathrm{NaCl}, \mathrm{KCl}, \mathrm{MgCl}_{2}$, and $\mathrm{CaCl}_{2}$ ), or $\left[\mathrm{Cu}\left(\mathrm{CH}_{3} \mathrm{CN}\right)_{4}\right] \mathrm{PF}_{4}$ (from $10 \mathrm{mM}$ stock solution in $\mathrm{MeCN}$ ) was added to give the final concentrations of $1 \mathrm{mM}$ for $\mathrm{Na}(\mathrm{I}), \mathrm{K}$ (I), $\mathrm{Mg}$ (II), and $\mathrm{Ca}(\mathrm{II})$ and $20 \mu \mathrm{M}$ for other metal ion species. The mixtures were kept at room temperature for $1 \mathrm{~h}$, and then fluorescence responses were measured by microplate readers (Glomax Multi Detection System, Promega, or SpectraMax iD3, Molecular Devices) with an appropriate filter set (excitation $=525 \mathrm{~nm}$, emission $=580-640 \mathrm{~nm}$ ).

Fluorescence responses of each probe to various metal ions were measured as follows. Stability tests against reductants, reactive oxygen species, and effect of chelator were tested under the conditions as follows.

$\mathrm{Na}_{2} \mathrm{~S}_{2} \mathrm{O}_{3} \quad: 100 \mu \mathrm{M}$ from $10 \mathrm{mM}$ stock solution in water

Sodium ascorbate $\quad: 100 \mu \mathrm{M}$ from $10 \mathrm{mM}$ stock solution in water

Cysteine $\quad: 100 \mu \mathrm{M}$ from $10 \mathrm{mM}$ stock solution in water

Glutathione $\quad: 1 \mathrm{mM}$ from $100 \mathrm{mM}$ stock solution in HEPES buffer (pH was adjusted to 7.4)

$\mathrm{NaNO}_{2} \quad: 100 \mu \mathrm{M}$ from $10 \mathrm{mM}$ stock solution in water

$\mathrm{O}_{2} \bullet^{-} \quad: 100 \mu \mathrm{M}$ from saturated $\mathrm{KO}_{2}$ solution in DMSO (ca. $\left.1 \mathrm{mM}\right)^{2}$

$\mathrm{H}_{2} \mathrm{O}_{2} \quad: 100 \mu \mathrm{M}$ from $10 \mathrm{mM}$ stock solution in water

$\cdot \mathrm{OH} \quad: 200 \mu \mathrm{M} \mathrm{H}_{2} \mathrm{O}_{2}$ and $20 \mu \mathrm{M} \mathrm{FeSO}_{4}(1 \mathrm{mM}$ stock solution of each probe in DMF was used instead of DMSO because DMSO is a quencher of hydroxyl radical ${ }^{3}$ )

$\mathrm{NaOCl} \quad: 100 \mu \mathrm{M}$ from $10 \mathrm{mM}$ stock solution in water

NO $\quad: 100 \mu \mathrm{M}$ NOC-5 from $10 \mathrm{mM}$ stock solution in $0.1 \mathrm{M} \mathrm{NaOH}$ aq.

$\mathrm{NADH} \quad: 100 \mu \mathrm{M}$ NADH from $10 \mathrm{mM}$ stock solution in $50 \mathrm{mM}$ HEPES buffer

Each probe $(2 \mu \mathrm{M})$ was incubated under each condition in 50 mM HEPES buffer $(\mathrm{pH} 7.4)$ for $1 \mathrm{~h}$, and then 
fluorescence responses were measured by a microplate reader (Glomax Multi Detection System, Promega) with an appropriate filter set (excitation $=525 \mathrm{~nm}$, emission $=580-640 \mathrm{~nm})$.

\section{Product analysis by LC-MS}

To a solution of a probe (final, $100 \mu \mathrm{M}$ ) in distilled water was added a solution of $\mathrm{Fe}\left(\mathrm{NH}_{4}\right)_{2}\left(\mathrm{SO}_{4}\right) \cdot 6 \mathrm{H}_{2} \mathrm{O}$ (final, 200 $\mu \mathrm{M})$. The mixture was kept for $1 \mathrm{~h}$ under an ambient condition. The products were analyzed with LC-MS system (Chromaster5110, Hitachi High-tech) equipped with a photodiode-array detector (Chromaster5430, Hitachi Hightech) and a mass spectrometer (Chromaster5610 MS Detector, Hitachi High-tech) and with Waters symmetry $\mathrm{C}_{18}$ column $\left(3.5 \mu \mathrm{m}, 4.6 \times 75 \mathrm{~mm}\right.$ ) eluted with a gradient system consisting of $\mathrm{H}_{2} \mathrm{O}$ (solvent $\mathrm{A}$ ) and $\mathrm{CH}_{3} \mathrm{CN}$ (solvent B) containing $0.05 \%$ formic acid; $20 \% \mathrm{~B}$ to $90 \% \mathrm{~B}$ over $20 \mathrm{~min}$. The retention times were compared with those of the parent dyes and probes in water. Assignments of the compounds were based on the observed $\mathrm{m} / \mathrm{z}$ values at each peak.

\section{Cell culture experiments}

Human hepatocellular carcinoma (HepG2) cells were cultured in modified essential medium (MEM, Gibco) containing 10\% fetal bovine serum (FBS, Gibco), 1\% Antibiotic-Antimyocotic (Gibco), and $2 \mathrm{mM}$ glutamine at $37{ }^{\circ} \mathrm{C}$ in a $5 \% \mathrm{CO}_{2} / 95 \%$ air incubator. For confocal fluorescence imaging experiments, two days before use, the cells $\left(5.0 \times 10^{4}\right.$ cells/well) were seeded on Advanced TC glass-bottomed dishes (CELL $L_{\text {view }}$ Cell Culture Dish, Greiner). For high throughput assay, two days before use, the cells $\left(1.2 \times 10^{4}\right.$ cells/well $)$ were seeded on PerkinElmer ViewPlate-96.

\section{Confocal fluorescence imaging experiments}

Confocal fluorescence images were acquired by using an Olympus IX83 microscope equipped with a $130 \mathrm{~W}$ mercury lump, an EMCCD camera (Hamamatsu Photonics, ImagEM), and a disk scan confocal unit (DSU, Olympus). Fluorescence images were obtained with a Rhodamine filter set (excitation $=532-554 \mathrm{~nm}$, emission $=$ $572-642 \mathrm{~nm}$, and dichroic mirror $=565 \mathrm{~nm}$ ). Experiments were performed with $20 \times$ objective lens, $40 \times$ objective lens, or $60 \times$ oil-immersion objective lens. For all imaging experiments, Hank's Balanced Salt Solution (HBSS, Gibco) containing calcium and magnesium without phenol red was used. For Fe(II) uptake experiments, cells were treated with $\mathrm{Fe}\left(\mathrm{NH}_{4}\right)_{2}\left(\mathrm{SO}_{4}\right)_{2} \bullet 6 \mathrm{H}_{2} \mathrm{O}$ (FAS) $(100 \mu \mathrm{M}$, from $10 \mathrm{mM}$ stock solution in water) in MEM without FBS at $37{ }^{\circ} \mathrm{C}$ for $30 \mathrm{~min}$. After wash with $\operatorname{HBSS}(\times 3)$, the cells were treated with probe $(1 \mu \mathrm{M}$, RhoNox-N, $\mathrm{N}=2-8$, from $100 \mu \mathrm{M}$ stock solution in DMSO). After incubation for $30 \mathrm{~min}$ at $37{ }^{\circ} \mathrm{C}$, the cells were washed with $\mathrm{HBSS}(\times 2)$, and then imaged. For chelation experiments, 2,2'-bipyridyl (Bpy) (1 mM, from $100 \mathrm{mM}$ stock solution in DMSO) was added to the cells simultaneously with probe. For the detection of endogenous Fe(II) experiments, multiple concentrations of Bpy $(0,1,5,10,50$, and $100 \mu \mathrm{M}$ from $0,0.1,0.5,1,5$, and $10 \mathrm{mM}$ stock solution in DMSO, respectively) in HBSS was added to the cells simultaneously with RhoNox-4 $(1 \mu \mathrm{M}$, from $100 \mu \mathrm{M}$ stock solution in DMSO) in HBSS for 30 min at $37^{\circ}$ C.For the imaging study on the effect of Pluronic F-127 (Thermo Fisher Scientific), the each stock solution of RhoNox-N ( $=2,3,5,6,7$, and 8) (2 $\mathrm{mM}$ in DMSO) were mixed with the same volume of Pluronic F-127 solution $(20 \%(\mathrm{w} / \mathrm{v})$, DMSO) to prepare the solutions of the probes $(1 \mathrm{mM})$ with $10 \%(\mathrm{w} / \mathrm{v})$ Pluronic F-127 in DMSO. Then, the cells were treated as above. 
For Fe(III) supplementation experiments, cells were treated with ferric ammonium citrate (FAC) $(100 \mu \mathrm{M}$, from 10 $\mathrm{mM}$ stock solution in water) in MEM without FBS at $37{ }^{\circ} \mathrm{C}$ for $30 \mathrm{~min}$. After wash with $\mathrm{HBSS}(\times 3)$, the cells were treated with RhoNox-4 (1 $\mu \mathrm{M}$, from $100 \mu \mathrm{M}$ stock solution in DMSO) in HBSS. After incubation for 30 min at $37{ }^{\circ} \mathrm{C}$, the cells were washed with HBSS $(\times 2)$, and then imaged. For the inhibition of ferrireductase, diphenyleneiodonium chloride (DPI) $(100 \mu \mathrm{M}$ from $10 \mathrm{mM}$ stock solution in DMSO) was added to the cells simultaneously with FAC. For all the control experiments, the corresponding amounts of vehicle (FAS and FAC: water, Bpy and DPI: DMSO) was added to the cells instead.

For the transferrin uptake experiments, after washing the cells with HBSS $(\times 2)$, the cells were incubated with holoTf ( $5 \mu \mathrm{M}$, Wako Pure Chemicals, from $100 \mu \mathrm{M}$ stock solution in HBSS $) \pm$ apoTf ( $25 \mu \mathrm{M}$, Nacalai Tesque, from 100 $\mu \mathrm{M}$ stock solution in HBSS) for $30 \mathrm{~min}$, at $37^{\circ} \mathrm{C}$, and then the cells were treated with RhoNox-4 for 30 min at $37^{\circ} \mathrm{C}$, washed with HBSS, and then imaged.

For co-staining experiments, cells were treated with Mitotracker Green FM (100 nM, Thermo Fisher Scientific inc.) (mitochondria, $1 \mathrm{~h}$ at $\left.37^{\circ} \mathrm{C}\right)$, ERtracker Green $(500 \mathrm{nM}$, Thermo Fisher Scientific inc.) (endoplasmic reticulum, $30 \mathrm{~min}$ at $37^{\circ} \mathrm{C}$ ), LysoTracker Green-DND ( $50 \mathrm{nM}$, Thermo Fisher Scientific inc) (lysosome, $30 \mathrm{~min}$ at $37^{\circ} \mathrm{C}$ ) or BODIPY-FL ceramide complexed to BSA ( $1 \mu \mathrm{M}$, Thermo Fisher Scientific inc.) (Golgi, 30 min at $\left.4{ }^{\circ} \mathrm{C}\right)$ in $\mathrm{HBSS}$ prior to treatment with RhoNox-4 $(1 \mu \mathrm{M})$ in HBSS for $30 \mathrm{~min}$ at $37{ }^{\circ} \mathrm{C}$. Fluorescence images of each organelle marker were obtained with a FITC filter set (excitation $=465-500 \mathrm{~nm}$, emission $=516-556 \mathrm{~nm}$, and dichroic mirror $=495 \mathrm{~nm})$. Colocalization analysis was performed by calculation of Pearson's correlation values $\left(R_{\text {coloc }}\right)$ for the

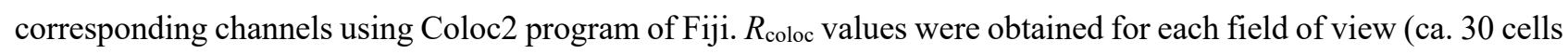
in each image on average), and the mean of $R_{\text {coloc }}$ values for each condition were calculated ( $\mathrm{N}=5: 5$ images for each condition were analyzed).

For the imaging study with lomofungin and the protease inhibitors, cells were treated with lomofungin $(10 \mu \mathrm{M})$ in the presence or absence of a cocktail of pepstatin A (PepA) $(50 \mu \mathrm{M}$, Merck) and E-64d $(25 \mu \mathrm{M})$ in MEM $(+10 \% \mathrm{FBS})$ for $3 \mathrm{~h}$ at $37^{\circ} \mathrm{C}$. The cells were washed with HBSS $(\times 2)$ and treated with RhoNox- 4 for $30 \mathrm{~min}$ at $37^{\circ} \mathrm{C}$. Then, the cells were washed with HBSS and imaged.

The average fluorescence intensities in the cells were quantified for each image ( $\mathrm{N}$ means the numbers of the fields of view analyzed) by using an automated evaluation process by ImageJ (background subtraction, thresholding to set ROI, and brightness measurement).

\section{High-throughput assay of a chemical library with RhoNox-4}

$1^{\text {st }}$ screening: Cell-based imaging assay. Two days before use, HepG2 cells $\left(1.2 \times 10^{4}\right.$ cells/well $)$ in MEM $(+10 \%$ FBS $)$ were seeded on PerkinElmer ViewPlate-96. A validated library containing 3,399 compounds of which biological activities are known was obtained from Drug Discovery Initiative, The University of Tokyo. The library compounds ( $2 \mathrm{mM}$ in DMSO) were diluted to $20 \mu \mathrm{M}$ with the medium ( $+10 \% \mathrm{FBS})(1 \% \mathrm{DMSO})$ prior to the addition to each plate. The same amount of the vehicle (DMSO) was added for the controls. The plate layout of highthroughput screening is shown in Supplementary Figure 20. For the maximum response, ferric ammonium citrate (FAC, $200 \mu \mathrm{M}$ ) was added to the wells E12-H12. For the minimum response, deferoxamine (DFO, $100 \mu \mathrm{M}$ ) was added to the wells E1-H1. The library compounds were added to rows 2-11. No cells were seeded to A1-D1 (bkg), and the vehicle (DMSO) was added to A12-D12 (Control) instead of the compounds. 
After the incubation of the cells under the conditions as above in a $\mathrm{CO}_{2}$ incubator at $37{ }^{\circ} \mathrm{C}$ for $3 \mathrm{~h}$, the cells were washed with HBSS, and then HBSS containing RhoNox-4 (1 $\mu \mathrm{M}, 0.5 \% \mathrm{DMSO})$ and Hoechst $33342(1 \mu \mathrm{g} / \mathrm{mL})$ was added to each well. Then, the cells were incubated in a $\mathrm{CO}_{2}$ incubator at $37^{\circ} \mathrm{C}$ for $30 \mathrm{~min}$. The cells were washed with HBSS $(\times 2)$, and fluorescence microscopic images were acquired by In Cell Analyzer 2200 (GE Healthcare) equipped with a $20 \times 0.45 \mathrm{NA}$ objective lens $\left(1^{\text {st }}\right.$ and $2^{\text {nd }}$ screening) or CellInsight CX5 (Thermo Fisher Scientific) equipped with a $20 \times 0.4 \mathrm{NA}$ objective lens ( $3^{\text {rd }}$ screening) by using appropriate filter sets (for Hoechst and RhoNox4). The average brightness of each image was analyzed by a In Cell Analyzer software ( $1^{\text {st }}$ and $2^{\text {nd }}$ screening) or Thermo Scientific HCS Studio ( $3^{\text {rd }}$ screening). Perinucleus regions $(<5 \mu \mathrm{m}$ from nucleus) exhibiting signals over a threshold were selected as the regions of interest (ROI), and the averages of the fluorescence intensities of the ROI were calculated automatically by the software programs. The results were evaluated by calculating $\left(\mathrm{F}-\mathrm{F}_{0}\right) / \mathrm{F}_{0}$, where $\mathrm{F}_{0}$ and $\mathrm{F}$ indicate the average intensities of the control (\#A12-D12) and the sample compounds, respectively. All the compounds were tested thrice $(n=3)$, and the average values were evaluated.

$1^{\text {st }}$ screening: Cell-free assay to exclude the compounds which react with the probe or have autofluorescence. The library compounds (final $20 \mu \mathrm{M}$ ) were added to a solution of RhoNox-4 $(1 \mu \mathrm{M})$ in HBSS in 96-well plates. DFO $(100 \mu \mathrm{M})$ and ferrous ammonium sulfate (FAS, $200 \mu \mathrm{M}$, as Fe(II) source) were used as the negative and positive control compounds, respectively. The plate layout is the same as the cell-based assay, and FAS was added instead of FAC. After incubation at $37^{\circ} \mathrm{C}$ for $3 \mathrm{~h}$, fluorescence intensities were measured by using a microplate reader (Glomax Multi Detection System, Promega) with an appropriate filter set (excitation $=525 \mathrm{~nm}$, emission $=$ $580-640 \mathrm{~nm})$. The results were evaluated by calculating $\left(\mathrm{F}-\mathrm{F}_{0}\right) / \mathrm{F}_{0}$, where $\mathrm{F}_{0}$ indicates the average intensities of the control.

$\mathbf{1}^{\text {st }}$ screening: Evaluation of the data. From the results of the $1^{\text {st }}$ screening, the compounds that show $\left(\mathrm{F}-\mathrm{F}_{0}\right) / \mathrm{F}_{0}>$ 0.5 and $<-0.3$ with CV (standard deviation/average of three measurements) $<0.2$ were selected as $1^{\text {st }}$ hit compounds, respectively. All the acquired images were also visually verified, and the compounds having severe cytotoxicity and autofluorescence or bearing chelating motives were excluded. 387 compounds in total were selected.

\section{$2^{\text {nd }}$ screening: Cell-based imaging assay.}

The obtained 387 hit compounds were applied to the $2^{\text {nd }}$ cell-based imaging assay. The protocol was the same with the $1^{\text {st }}$ screening, but the sample concentrations were $10 \mu \mathrm{M}$ and $1 \mu \mathrm{M}$. The library compounds $\left(10 \mathrm{mM}\left(2^{\text {nd }}\right)\right.$ in DMSO) were diluted to the desired concentrations $(10 \mu \mathrm{M}$ or $1 \mu \mathrm{M})$ with the medium $(+10 \% \mathrm{FBS})(1 \%$ or $0.2 \%$ $\mathrm{DMSO})$ prior to the addition to each plate. From the results of the $2^{\text {nd }}$ screening, the compounds that show $\left(\mathrm{F}-\mathrm{F}_{0}\right) / \mathrm{F}_{0}$ $>0.5$ or $<-0.3$ with $\mathrm{CV}<0.2$ were selected as $2^{\text {nd }}$ hit compounds, respectively. No significant hit compounds were obtained from $1 \mu \mathrm{M}$ assay, and thus we chose the hit compounds by evaluating the $10 \mu \mathrm{M}$ assay results. The evaluation protocol was the same as the $1^{\text {st }}$ screening. 28 compounds in total were selected as hit compounds.

\section{$3^{\text {rd }}$ screening: Cell-based imaging assay.}

The obtained 28 hit compounds were applied to the $3^{\text {rd }}$ cell-based imaging assay, according to the protocol of $1^{\text {st }}$ screening. In this assay, the reproducibility of the assay at $10 \mu \mathrm{M}$ and the activity at lower concentration $(5 \mu \mathrm{M})$ were evaluated. 
$3^{\text {rd }}$ screening: Cell-free fluorescence assay in the presence of $\mathbf{F e}(\mathrm{II})$. We applied the 28 hit compounds to cellfree fluorescence measurements in the presence of $\mathrm{Fe}(\mathrm{II})$. This assay could exclude the compounds that accelerate the $\mathrm{Fe}$ (II)-induced $N$-oxide reduction of the probe, which resulted in the false positive hits. The compounds $(10 \mu \mathrm{M})$ were mixed with RhoNox-4 $(1 \mu \mathrm{M})$ in 50 mM HEPES buffer (pH7.4), and ferrous sulfate $\left(\mathrm{FeSO}_{4}, 10 \mu \mathrm{M}\right)$ was added. After incubation for $37^{\circ} \mathrm{C}$ for $30 \mathrm{~min}$, fluorescence intensities were measured by using a microplate reader (Glomax Multi Detection System, Promega) using an appropriate filter set (excitation $=525 \mathrm{~nm}$, emission $=580$ $640 \mathrm{~nm}$ ). From the results of $3^{\text {rd }}$ screening, we determined the final hit compound that showed reproducible activity at $10 \mu \mathrm{M}$, the highest activity at $5 \mu \mathrm{M}$, and neither inhibition nor acceleration effect on the probe's fluorogenic reaction.

\section{Western blot of DMT-1, ferritin, transferrin receptor, and IRP-2}

The HepG2 cells were seeded $\left(1.5 \times 10^{5}\right.$ cells $)$ on a $6 \mathrm{~cm}$ dish and incubated in MEM $(10 \% \mathrm{FBS})$ for $24 \mathrm{~h}$. Then, the cells were treated with the compounds $(10 \mu \mathrm{M}, 0.1 \% \mathrm{DMSO})$ in MEM $(10 \% \mathrm{FBS})$ at $37^{\circ} \mathrm{C}$ for $3 \mathrm{~h}$. The cells were washed with cold phosphate buffered saline (PBS) twice and then collected by a cell scraper. The cells were centrifuged and then lysed by RIPA (radio-immunoprecipitation assay) buffer ( $80 \mu \mathrm{L})$ on ice for $30 \mathrm{~min}$. The lysate was centrifuged $\left(14,000 \mathrm{rpm}, 4{ }^{\circ} \mathrm{C}, 10 \mathrm{~min}\right)$. The supernatant was obtained as protein samples. The total concentration of protein was determined using Pierce BCA protein assay kit (Thermo Fisher Scientific). The cell extracts (50 $\mu \mathrm{g}$ for DMT1; $15 \mu \mathrm{g}$ for ferritin, ferroportin, transferrin receptor, and IRP2;) were subjected to SDSPAGE (12.5\% for DMT1, and 10\% for others). SDS-PAGE was performed under constant voltage at $200 \mathrm{~V}$ at room temperature for $40 \mathrm{~min}$. The separated proteins in polyacrylamide gel were transferred to a PVDF membrane under constant voltage at $15 \mathrm{~V}$ for $20 \mathrm{~min}$. The PVDF membranes were incubated in $5 \%(\mathrm{w} / \mathrm{v})$ skim milk at room temperature for $1 \mathrm{~h}$. After the blocking reaction, the membrane was incubated for $1 \mathrm{~h}$ in Tris-buffered saline (20 $\mathrm{mM})$ containing tween $20(0.1 \% \mathrm{w} / \mathrm{v})$ with primary antibodies against $\beta$-actin (1:3000, Sigma, A2228, monoclonal, mouse), ferritin (1:2000, Abcam, ab75973, monoclonal, rabbit), ferroportin (1:1000, Novus Biologicals, NBP121502, polyclonal, rabbit), IRP2 (1:1000, Novus Biologicals, NBP100-1798, polyclonal, rabbit), transferrin receptor (1:1000, Abcam, ab84036, polyclonal, rabbit), and DMT1 (1:100, Abcam, ab55735, monoclonal, mouse). After the primary antibody reaction, the membrane was incubated with the secondary antibody against goat anti-rabbit or goat anti-mouse IgG conjugated with HRP (1:2500 (anti-rabbit) 1:2000 (anti-mouse), respectively, Sigma, A6154 and A4416). The membranes were incubated with Western Blotting Substrate (Pierce) according to the manufacturer's protocol, and the chemiluminescence were measured by a ChemiDoc Touch imaging system (BIORAD). The band density was quantified by ImageJ software. For IRP2 detection, the imaged membranes were blocked by the skim mild solution again, and $\beta$-actin was imaged as above. For the detection of ferroportin, $\beta$-actin level was assayed after the deactivation of $\mathrm{HRP}$ by the treatment with $15 \% \mathrm{H}_{2} \mathrm{O}_{2}$ for $1 \mathrm{~h}$.

\section{Cytotoxicity assay}

The HepG2 cells $\left(1.0 \times 10^{4}\right.$ cells $)$ were seeded to each well of a 96-well plate. The cells were incubated in MEM $(+10 \% \mathrm{FBS})$ at $37^{\circ} \mathrm{C}$ for $24 \mathrm{~h}$. The compounds diluted to the desired concentrations $(0.1-20 \mu \mathrm{M}, 1 \% \mathrm{DMSO})$ in MEM were added to the cells. The cells were incubated for $3 \mathrm{~h}$ or $24 \mathrm{~h}$ in a $\mathrm{CO}_{2}$ incubator. The cells were treated with thiazolyl blue tetrazolium bromide (MTT reagent, Sigma Aldrich, final $0.5 \mathrm{mg} / \mathrm{mL}$ form $5 \mathrm{mg} / \mathrm{mL}$ stock 
solution) at room temperature for $4 \mathrm{~h}$. After the removal of the medium, DMSO $(100 \mu \mathrm{M})$ was added to each well, and absorption at $560 \mathrm{~nm}$ was measured by a microplate reader. The cell viabilities were calculated from the absorption.

\section{Quantification of total intracellular iron by atomic absorption spectrometry}

HepG2 cells $\left(5.0 \times 10^{6}\right.$ cells $)$ were seeded on a plastic dish $(6 \mathrm{~cm}) 2$ days prior to use. Then, HepG2 cells were incubated with or without lomofungin $(20 \mu \mathrm{M})$ for $3 \mathrm{~h}$ in MEM $(+10 \% \mathrm{FBS})$. The medium was washed with cold phosphate-buffered saline (PBS, $6 \mathrm{~mL} \times 3$ ). The cells were removed from the dishes by using a scraper, and then the suspension was centrifuged (1,000 rpm, $5 \mathrm{~min}$ ). The supernatant was carefully removed, and the cells were resuspended into conc. $\mathrm{HNO}_{3}(100 \mu \mathrm{L})$. The suspension was heated at $90{ }^{\circ} \mathrm{C}$ for $4 \mathrm{~h}$ to dissolve the cell bodies. The lysate was diluted to $2 \mathrm{~mL}$ with distilled water. Concentrations of iron in the samples were measured by furnace atomic absorption spectroscopy with a Shimadzu AA-7000 atomic absorption spectrometer. The obtained values $(\mathrm{ng} / \mathrm{mL})$ were normalized with the cell numbers (per $10^{6}$ cells).

\section{RNA preparation and qRT-PCR}

HepG2 cells $\left(1.0 \times 10^{5}\right.$ cells $)$ were seeded on a 6 -well plastic dish $(6 \mathrm{~cm}) 2$ days prior to use. Then, HepG2 cells were incubated with or without lomofungin $(20 \mu \mathrm{M})$ for $3 \mathrm{~h}$ in MEM $(+10 \% \mathrm{FBS})$. Then, the cells were washed with PBS. The total RNA of the cells was extracted with TRI reagent in accordance with the manufacturer's instructions (Sigma-Aldrich). Total RNA (1 $\mu$ g per sample) was reverse transcribed to cDNA by using ReverTra Ace qPCR RT Master Mix (Toyobo). qRT-PCR was performed using THUNDERBIRD SYBR qPCR Mix (Toyobo) and amplified using a StepOne Real-Time PCR System (Thermo Fisher Scientific). Primers used in the real time RT-PCR analysis

were: ferritin heavy chain (Ft) (forward: 5'-AATTGGGTGACCACGTGACC-3'; reverse: 5'TTCCGCCAAGCCAGATTC-3') and glyceraldehyde-3-phosphate dehydrogenase (GAPDH) (forward: 5'TGGTGAAGACGCCAGTGGA-3'; reverse: 5'-GCACCGTCAAGGCTGAGAAC-3'). The level of GAPDH cDNA in the sample was used as an internal control for PCR amplification reactions. The $\mathrm{C}_{\mathrm{T}}$ values obtained for $\mathrm{Ft}$ were standardized by those of GAPDH.

\section{Statistics}

Error bars indicate standard error of the mean (s.e.m.) unless otherwise indicated. When means of three or more samples were calculated and compared, statistical significance was determined by Student's $t$-test or one-way ANOVA tests with Dunnett's test. Statistical significance is indicated by $* P<0.01$ and $* * P<0.001$.

\section{References for supporting information}

1) Grimm, J. B.; Lavis, L. D. Synthesis of Rhodamines from Fluoresceins Using Pd-Catalyzed C-N Cross-Coupling. Org. Lett. 2011, 13, 6354.

2) Lippert, A. R.; New, E. J.; Chang, C. J. Reaction-Based Fluorescent Probes for Selective Imaging of Hydrogen Sulfide in Living Cells. J. Am. Chem. Soc. 2011, 133, 10078.

3) Setsukinai, K.; Urano, Y.; Kakinuma, K.; Majima, H. J.; Nagano, T. Development of Novel Fluorescence Probes That Can Reliably Detect Reactive Oxygen Species and Distinguish Specific Species. J. Biol. Chem. 2003, 278, 
3170.

4) Hirayama, T.; Okuda, K.; Nagasawa, H. A highly selective turn-on fluorescent probe for iron (II) to visualize labile iron in living cells. Chem. Sci. 2013, 4, 1250. 


\section{Supporting Tables and Figures}

Table S1. Photophysical properties of RhoNox-N (N = 1-8)

\begin{tabular}{|c|c|c|c|c|c|}
\hline RhoNox-N & V $x$ & $\lambda_{a b s}(\mathrm{~nm})$ & $\varepsilon\left(\mathbf{M}^{-1} \mathbf{c m}^{-1}\right)$ & $\Phi$ & yields $^{b}$ \\
\hline$N=1$ & - & 492 & 24,000 & 0.01 & $14 \%^{\mathrm{c}}$ \\
\hline 2 & $\mathrm{CH}_{2}$ & 497 & 18,400 & n.d. ${ }^{d}$ & $31 \%$ \\
\hline 3 & 0 & 493 & 3,200 & n.d. ${ }^{d}$ & $21 \%$ \\
\hline 4 & N-Boc & 493 & 4,000 & n.d. ${ }^{d}$ & $69 \%$ \\
\hline 5 & $\mathrm{~N}-\mathrm{Ac}$ & 493 & 4,200 & n.d. ${ }^{d}$ & $47 \%$ \\
\hline 6 & N-COPy & 495 & 3,000 & n.d. ${ }^{d}$ & $63 \%$ \\
\hline 7 & $\mathrm{~N}-\mathrm{CO}_{2} \mathrm{Et}$ & t 489 & 4,400 & n.d. ${ }^{d}$ & $56 \%$ \\
\hline 8 & N-Piv & 489 & 3,400 & n.d. ${ }^{d}$ & $53 \%$ \\
\hline
\end{tabular}

a All the measurements were done in $50 \mathrm{mM} \mathrm{HEPES} \mathrm{buffer} \mathrm{(pH} \mathrm{7.4,} \mathrm{0.2 \% DMSO)}$

${ }^{\mathrm{b}}$ Reaction yields of the probes and $\mathrm{Fe}(\mathrm{II})$. Calculated from the UV-vis spectral change

and extinction co-efficients.

${ }^{c}$ Ref 4: Hirayama et al. Chem. Sci. 2013, 4, 1250.

${ }^{d}$ n.d. $=$ not determined.

Table S2. Photophysical properties of Rhodamine-N (N = 1-8)

\begin{tabular}{|c|c|c|c|c|c|}
\hline Rhodamine-N & $N X$ & $\lambda_{a b s}(\mathrm{~nm})$ & $\varepsilon\left(\mathbf{M}^{-1} \mathbf{c m}^{-1}\right)$ & $\lambda_{\text {em }}(\mathrm{nm})$ & $\Phi$ \\
\hline$N=1$ & - & 555 & 114,000 & 575 & 0.78 \\
\hline 2 & $\mathrm{CH}_{2}$ & 560 & 79,200 & 590 & 0.08 \\
\hline 3 & 0 & 545 & 72,800 & 575 & 0.10 \\
\hline 4 & N-Boc & 545 & 73,500 & 575 & 0.19 \\
\hline 5 & $\mathrm{~N}-\mathrm{Ac}$ & 545 & 79,400 & 575 & 0.34 \\
\hline 6 & N-COPy & 545 & 91,000 & 575 & 0.54 \\
\hline 7 & $\mathrm{~N}-\mathrm{CO}_{2} \mathrm{Et}$ & t 545 & 100,900 & 575 & 0.30 \\
\hline 8 & N-Piv & 545 & 81,500 & 575 & 0.40 \\
\hline
\end{tabular}


a

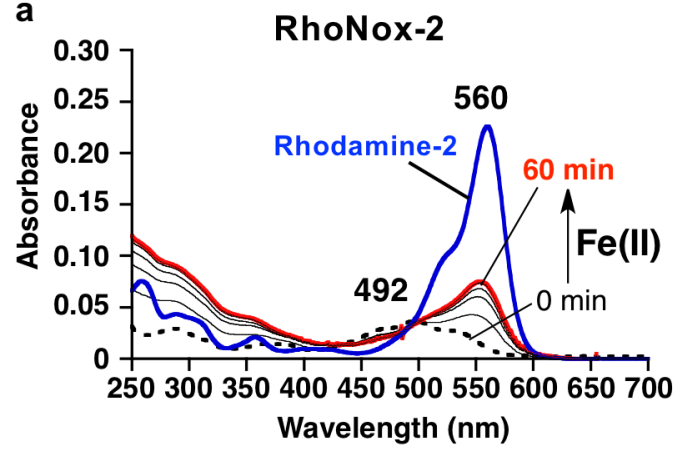

C

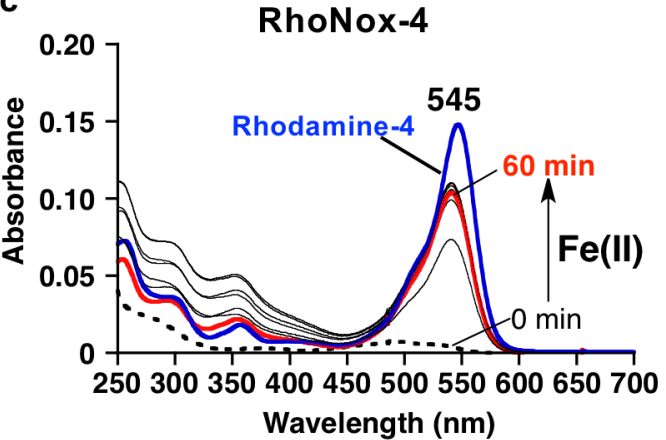

e

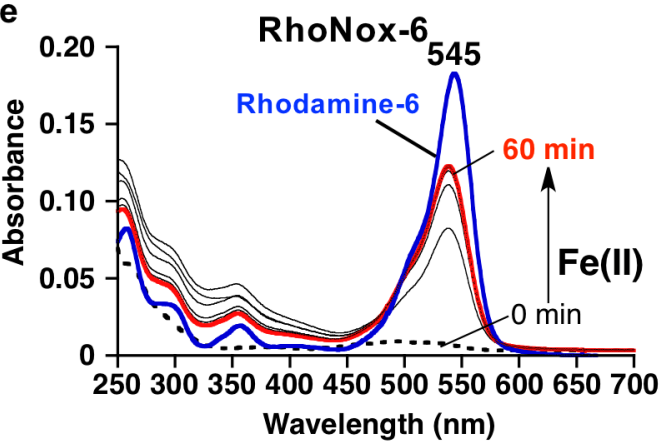

g

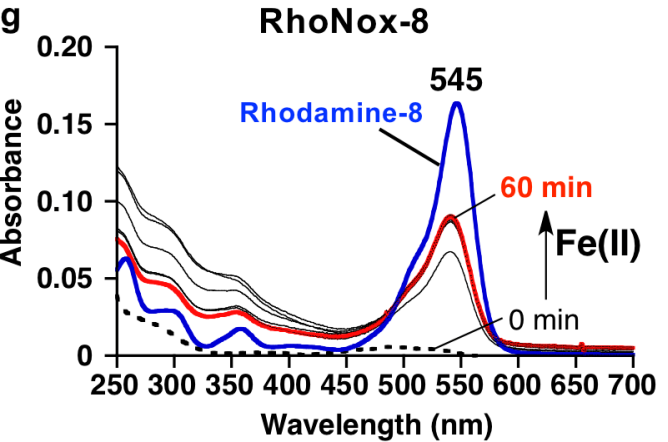

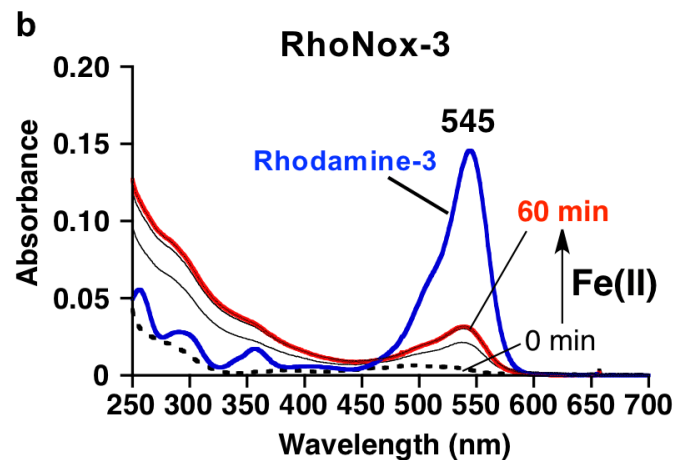

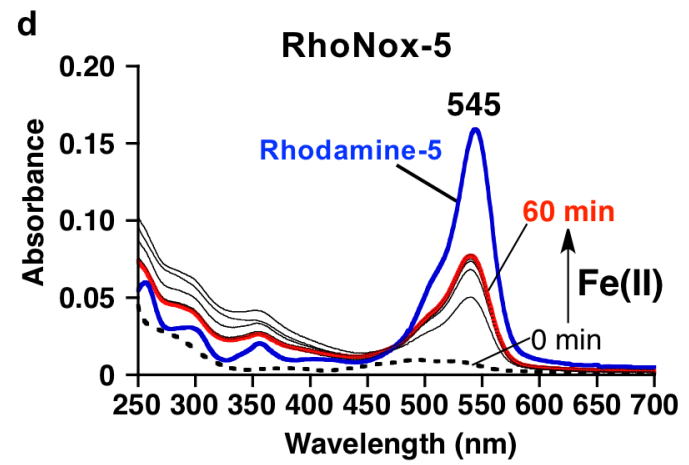

f

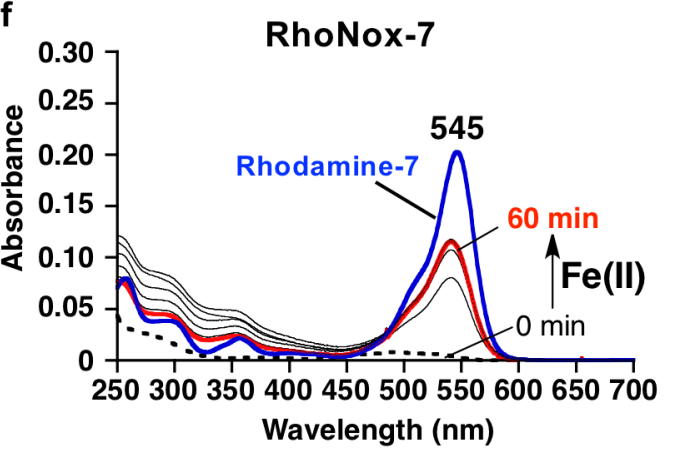

Figure S1. Absorption spectra of RhoNox-N and Rhodamine-N $(\mathrm{N}=2-8)$, and absorption spectral change of RhoNox-N upon the reaction with Fe(II) ion. (a) RhoNox-2 and Rhodamine-2. (b) RhoNox-3 and Rhodamine-3. (c) RhoNox-4 and Rhodamine-4. (d) RhoNox-5 and Rhodamine-5. (e) RhoNox-6 and Rhodamine-6. (f) RhoNox-7 and Rhodamine-7. (g) RhoNox-8 and Rhodamine-8. The concentrations of the probes (RhoNox-N), dyes (Rhodamine-N), and $\mathrm{Fe}\left(\mathrm{II}\right.$ ) (supplemented as $\mathrm{FeSO}_{4} \cdot 7 \mathrm{H}_{2} \mathrm{O}$ ) were $2 \mu \mathrm{M}, 2 \mu \mathrm{M}$, and $20 \mu \mathrm{M}$, respectively. Dashed lines indicate RhoNox-N, and blue lines indicate Rhodamine- $\mathrm{N}(\mathrm{N}=2-8)$. The spectral changes were acquired every 10 min as indicated by solid lines, and the red lines indicate the spectra of RhoNox-N $(\mathrm{N}=2-8) 60$ min after the addition of $\mathrm{Fe}(\mathrm{II})$. All the measurements were performed in $50 \mathrm{mM}$ HEPES buffer ( $\mathrm{pH}$ 7.4) 

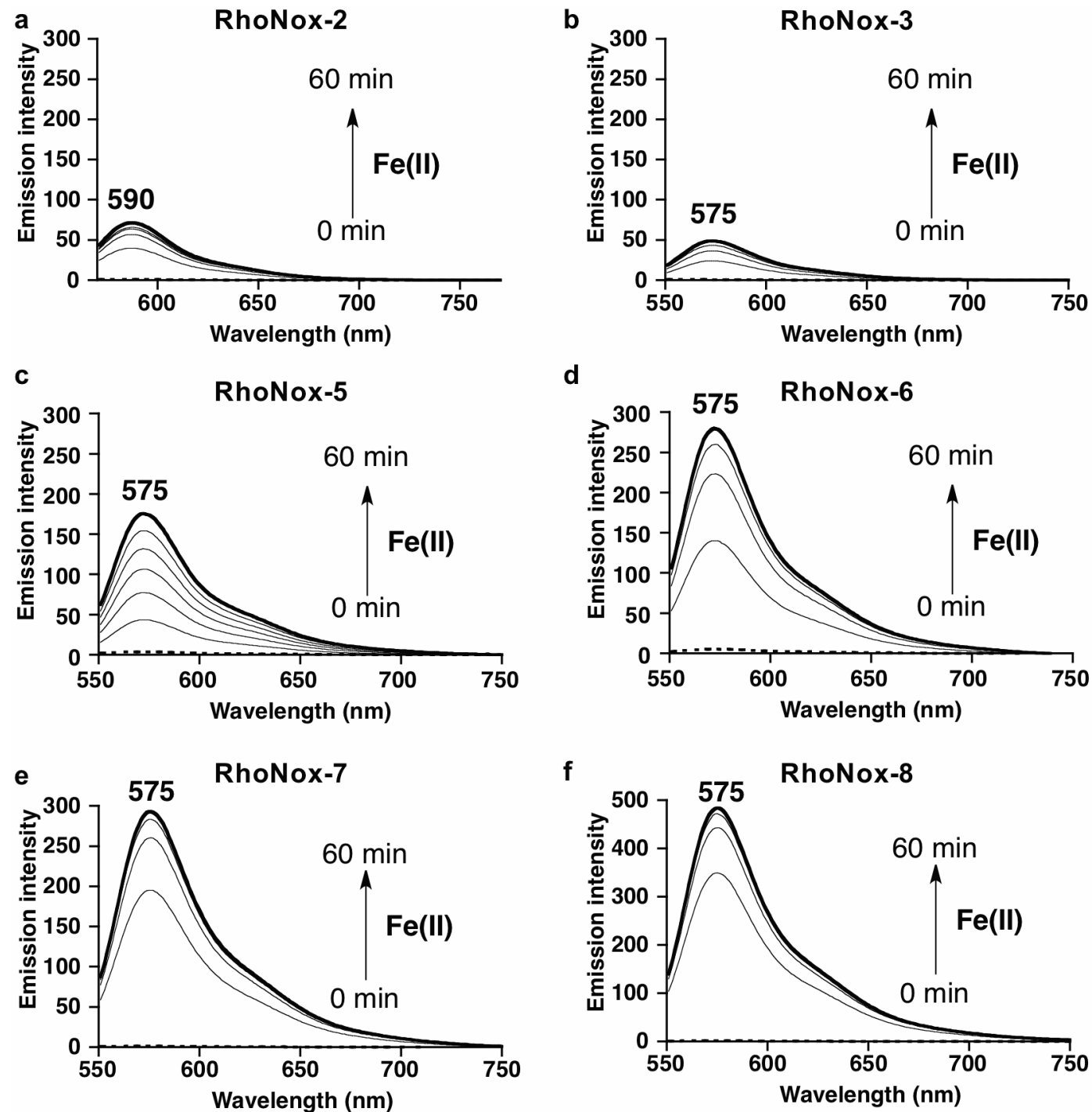

Figure S2. Fluorescence spectral changes (absolute intensity) of RhoNox-N ( $\mathrm{N}=2-8$, except for 4 ) upon the addition of Fe(II) ion. (a) RhoNox-2. (b) RhoNox-3. (c) RhoNox-5. (d) RhoNox-6. (e) RhoNox-7. (f) RhoNox-8. The concentrations of the probes and $\mathrm{Fe}(\mathrm{II})$ (supplemented as $\mathrm{FeSO}_{4}$ ) were $2 \mu \mathrm{M}$ and $20 \mu \mathrm{M}$, respectively. Dashed lines indicate RhoNox- $(\mathrm{N}=2-8)$. The spectral changes were acquired every $10 \mathrm{~min}$ as indicated by solid lines, and the bold lines indicate the spectra of RhoNox-N $(\mathrm{N}=2-8) 60$ min after the addition of Fe(II). All the measurements were performed in $50 \mathrm{mM}$ HEPES buffer ( $\mathrm{pH}$ 7.4). $\lambda_{\mathrm{ex}}=560 \mathrm{~nm}$ (for RhoNox-2) or $540 \mathrm{~nm}$ (for others). 

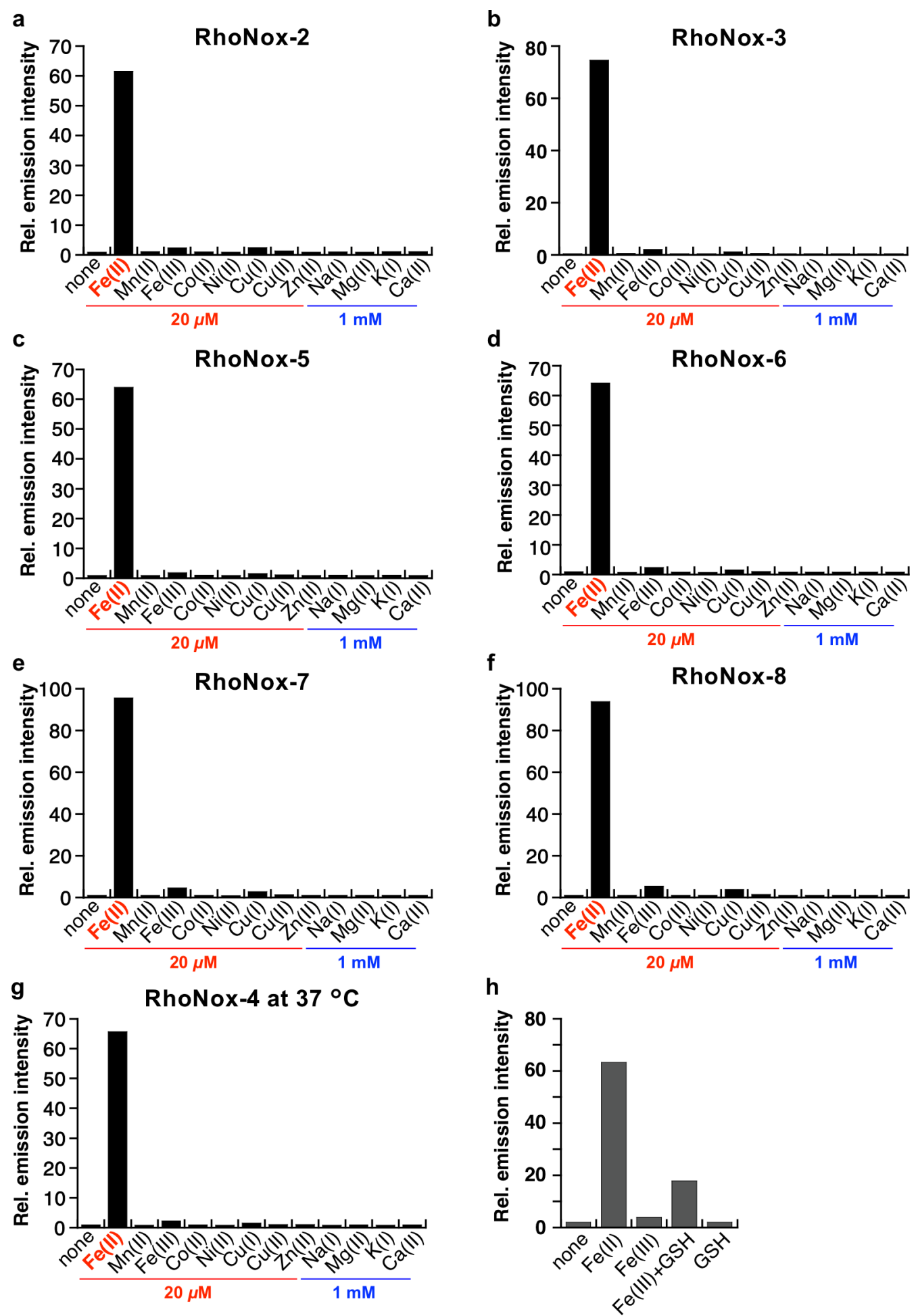

Figure S3. Fluorescence response of the probes upon addition of various metal ions. (a) RhoNox-2, (b) RhoNox3, (c) RhoNox-5, (d) RhoNox-6, (e) RhoNox-7, and (f) RhoNox-8, and (g) RhoNox-4 (at $37^{\circ} \mathrm{C}$ ). The concentrations of metal ions were $1 \mathrm{mM}$ for $\mathrm{Na}^{+}, \mathrm{Mg}^{2+}, \mathrm{K}^{+}$, and $\mathrm{Ca}^{2+}$, and $20 \mu \mathrm{M}$ for all other metal ions. All the data were acquired with $2 \mu \mathrm{M}$ probes after incubation for $1 \mathrm{~h}$ in $50 \mathrm{mM}$ HEPES buffer ( $\mathrm{pH} 7.4,0.2 \% \mathrm{DMSO}$ ) at room temperature (af) or at $37{ }^{\circ} \mathrm{C}$ (g). (h) Fluorescence response of RhoNox-4 to Fe(II) $(20 \mu \mathrm{M}), \mathrm{Fe}(\mathrm{III})(20 \mu \mathrm{M})$, glutathione (GSH, 1 $\mathrm{mM})$, and $\mathrm{Fe}(\mathrm{III})(20 \mu \mathrm{M})+\mathrm{GSH}(1 \mathrm{mM})$ after incubation for $1 \mathrm{~h}$ in $50 \mathrm{mM}$ HEPES buffer (pH7.4). Bars represent the relative fluorescence intensities at $580-640 \mathrm{~nm}\left(\lambda_{\mathrm{ex}}=525 \mathrm{~nm}\right)$. 
a

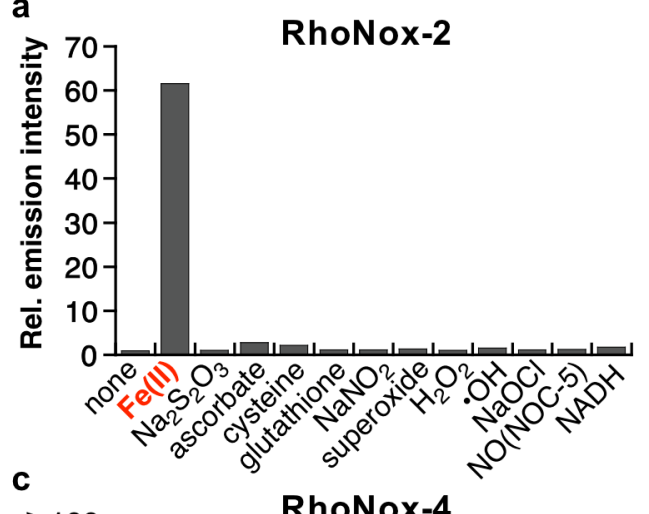

C

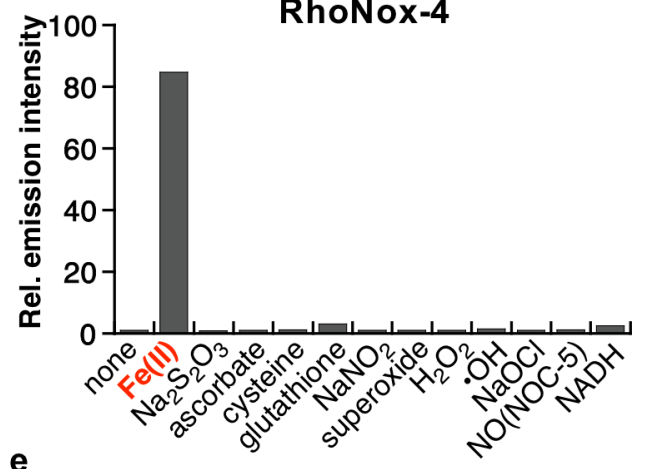

e RhoNox-6

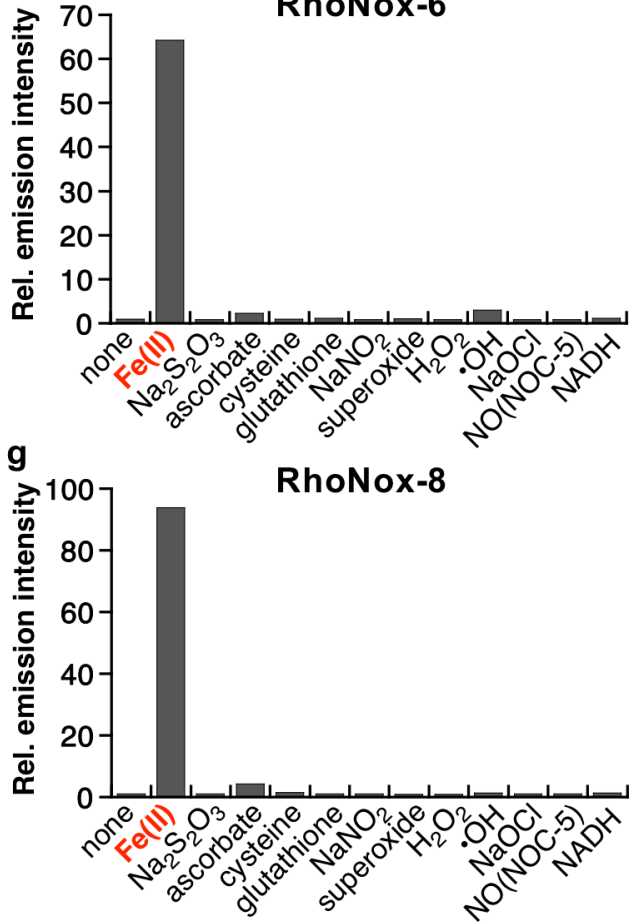

b

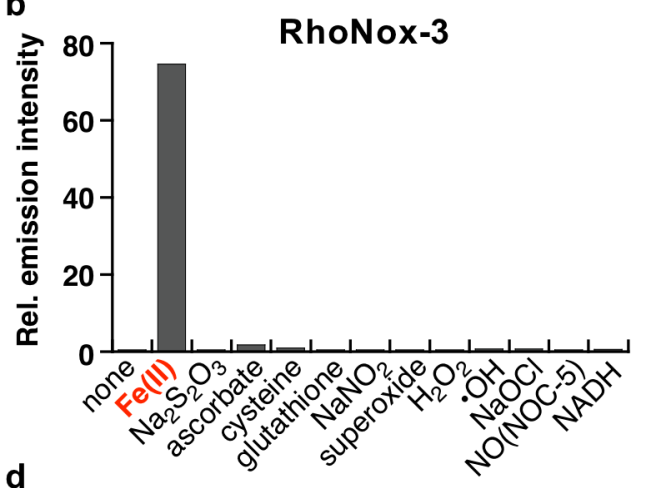

d
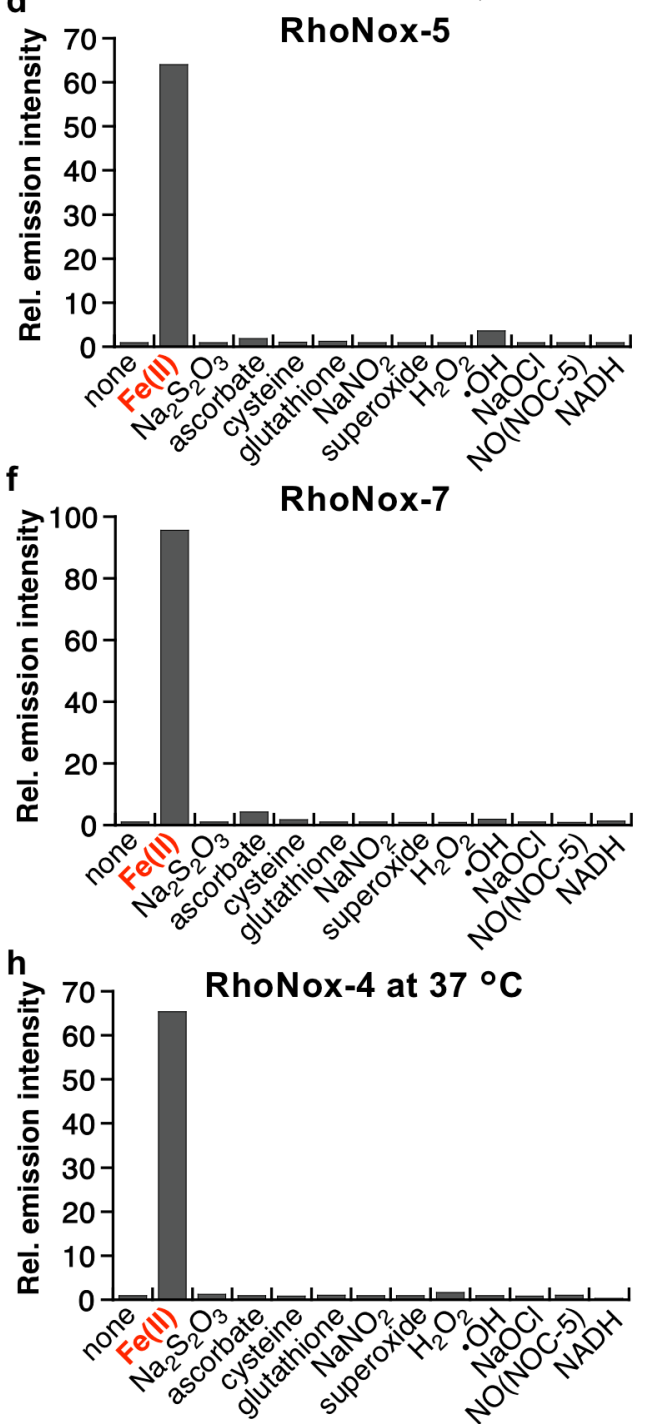

Figure S4. Fluorescence response of the probes over various biological reactive oxygen species, reactive nitrogen species, and reductants. (a) RhoNox-2, (b) RhoNox-3, (c) RhoNox-4, (d) RhoNox-5, (e) RhoNox-6, (f) RhoNox-7, (g) RhoNox-8, and (h) RhoNox-4 (at $37{ }^{\circ} \mathrm{C}$ ). The reagents and their concentrations were as follows. None: probe only, $\mathrm{Fe}(\mathrm{II}): 20 \mu \mathrm{M}, \mathrm{Na}_{2} \mathrm{~S}_{2} \mathrm{O}_{3}: 100 \mu \mathrm{M}$, sodium ascorbate: $1 \mathrm{mM}$, cysteine: $100 \mu \mathrm{M}$, glutathione: $1 \mathrm{mM}, \mathrm{NaNO}_{2}$ : $100 \mu \mathrm{M}, \mathrm{O}_{2}{ }^{-}: 100 \mu \mathrm{M}, \mathrm{H}_{2} \mathrm{O}_{2}: 100 \mu \mathrm{M}, \cdot \mathrm{OH}: 200 \mu \mathrm{M} \mathrm{H}_{2} \mathrm{O}_{2}+20 \mu \mathrm{M} \mathrm{FeSO}_{4}, \mathrm{NaOCl}: 100 \mu \mathrm{M}, \mathrm{NO}: 100 \mu \mathrm{M}$ (supplemented as NOC-5), NADH: $100 \mu \mathrm{M}$. All the data were acquired with $2 \mu \mathrm{M}$ probes after incubation for $1 \mathrm{~h}$ in $50 \mathrm{mM}$ HEPES buffer ( $\mathrm{pH} 7.4)$ at room temperature $(\mathrm{a}-\mathrm{g})$ or at $37^{\circ} \mathrm{C}(\mathrm{h})$. Bars represent relative fluorescence intensities at $580-640 \mathrm{~nm}\left(\lambda_{\mathrm{ex}}=525 \mathrm{~nm}\right)$. 

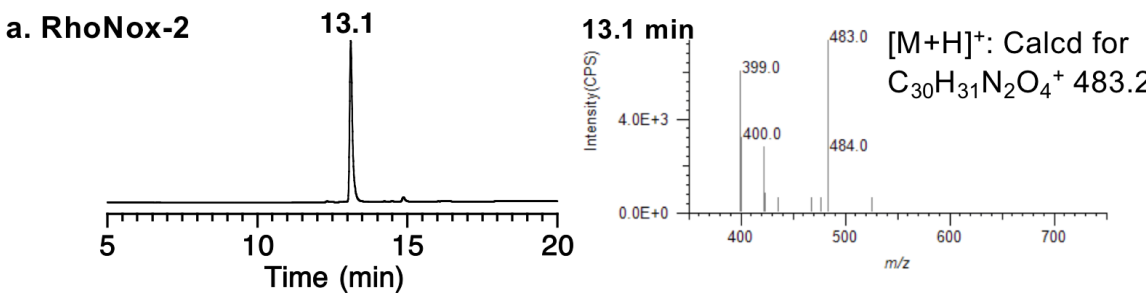

b. RhoNox-2+Fe(II)
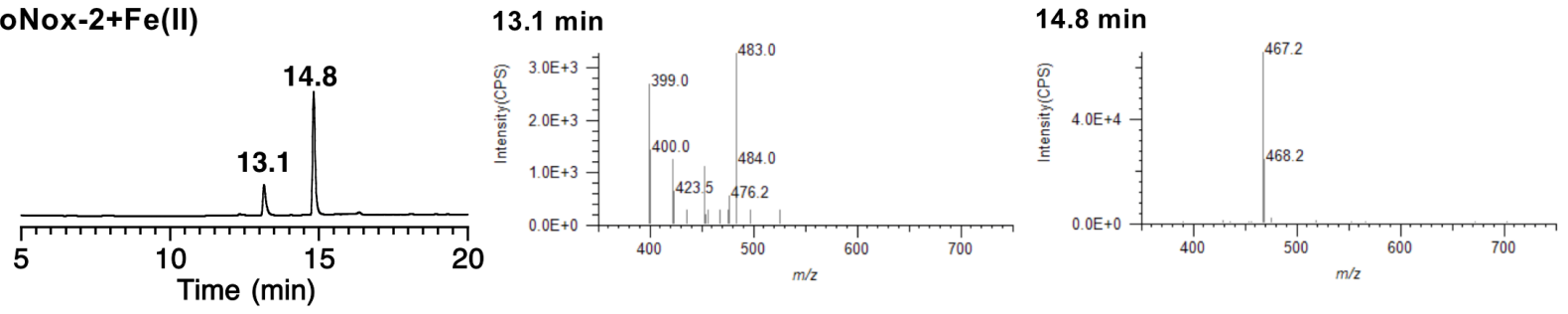

c. Rhodamine-2
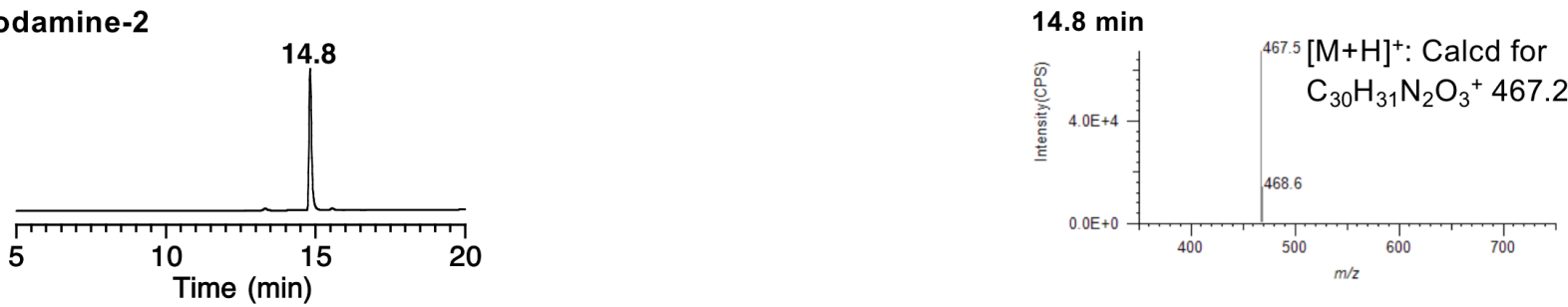

Figure S5. LC-MS analysis of the Fe(II)-triggered deoxygenation reaction of RhoNox-2. HPLC charts of (a) RhoNox-2, (b) the reaction mixture of RhoNox-2 and Fe(II) (2 eq., supplemented as FAS), and (c) Rhodamine-2. The sample concentrations were $100 \mu \mathrm{M}$. The absorbance at $254 \mathrm{~nm}$ was monitored. Mass spectra acquired at the indicated retention times were also shown with the calculated $\mathrm{m} / \mathrm{z}$.

a. RhoNox-3

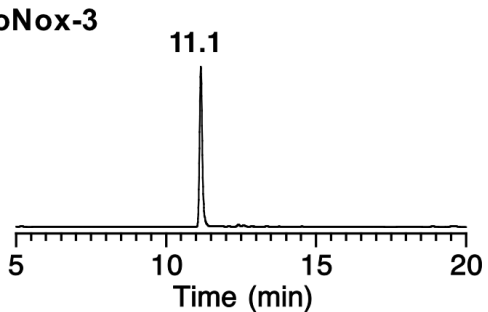

b. RhoNox-3+Fe(II)

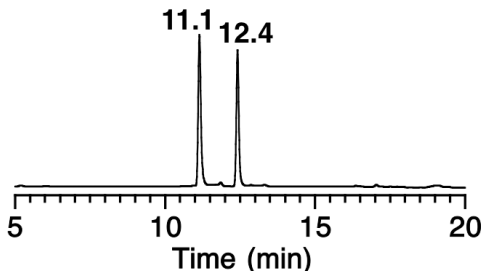

c. Rhodamine-3

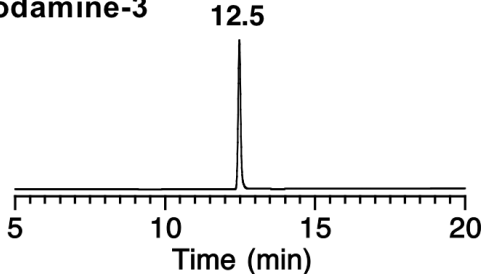

$11.1 \mathrm{~min}$

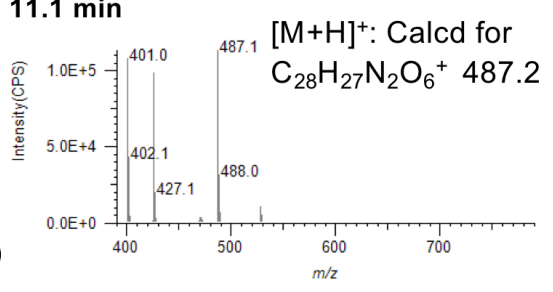

$11.1 \mathrm{~min}$

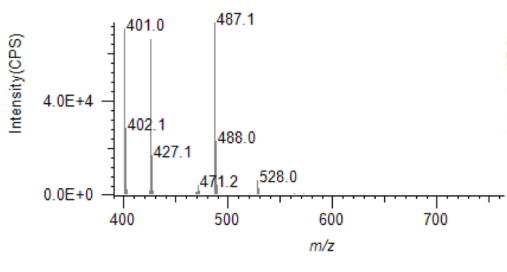

$12.4 \mathrm{~min}$
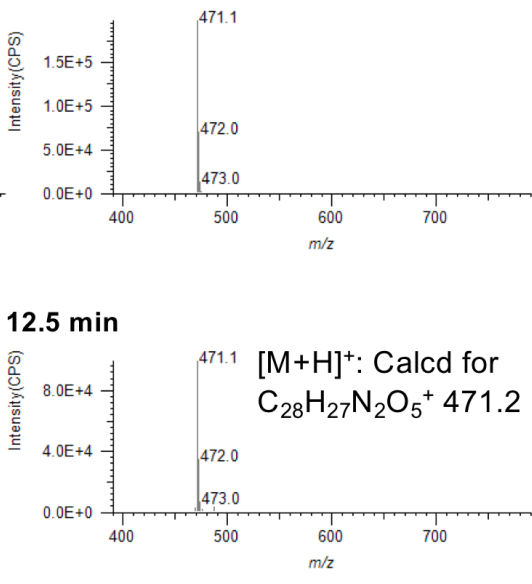

Figure S6. LC-MS analysis of the Fe(II)-triggered deoxygenation reaction of RhoNox-3. HPLC charts of (a) RhoNox-3, (b) the reaction mixture of RhoNox-3 and Fe(II) (2 eq., supplemented as FAS), and (c) Rhodamine-3. The sample concentrations were $100 \mu \mathrm{M}$. The absorbance at $254 \mathrm{~nm}$ was monitored. Mass spectra acquired at the indicated retention times were also shown with the calculated $\mathrm{m} / \mathrm{z}$. 

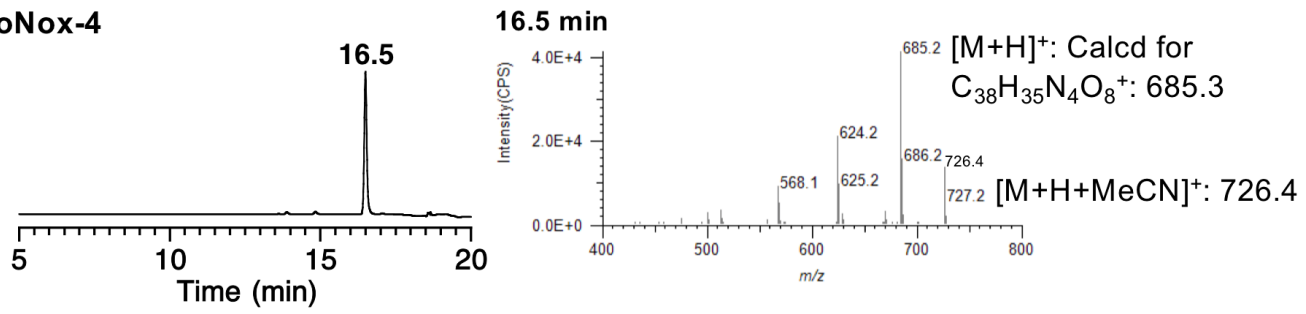

b. RhoNox-4+Fe(II)
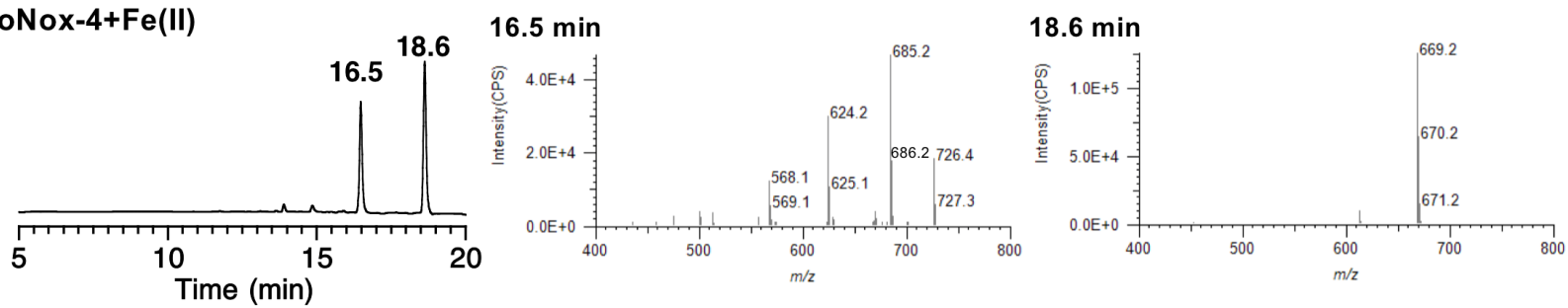

c. Rhodamine-4
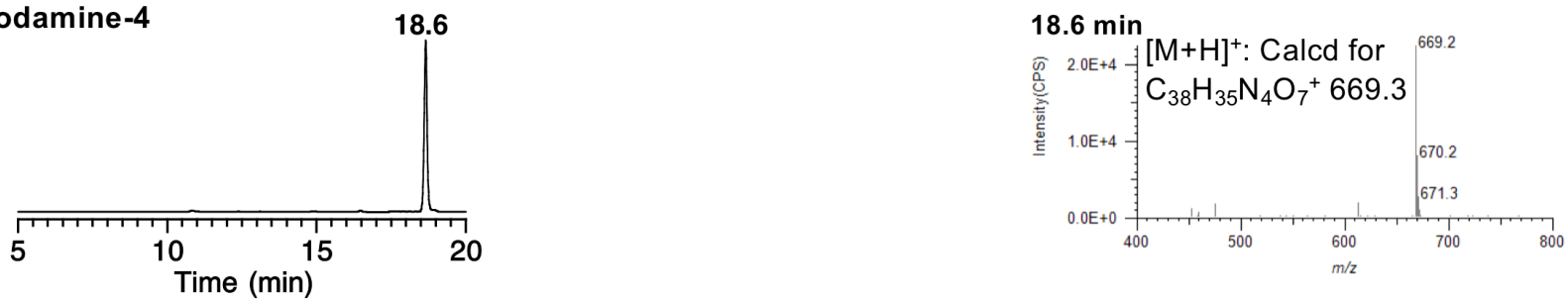

Figure S7. LC-MS analysis of the Fe(II)-triggered deoxygenation reaction of RhoNox-4. HPLC charts of (a) RhoNox-4, (b) the reaction mixture of RhoNox-4 and Fe(II) (2 eq., supplemented as FAS), and (c) Rhodamine-4. The sample concentrations were $100 \mu \mathrm{M}$. The absorbance at $254 \mathrm{~nm}$ was monitored. Mass spectra acquired at the indicated retention times were also shown with the calculated $\mathrm{m} / \mathrm{z}$.

a. RhoNox-5

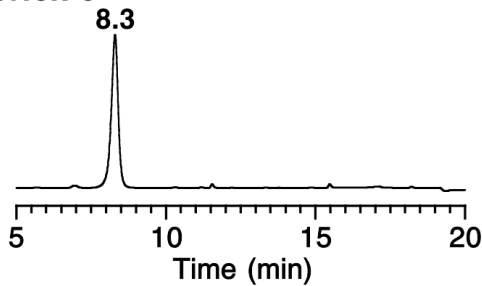

b. RhoNox-5+Fe(II)

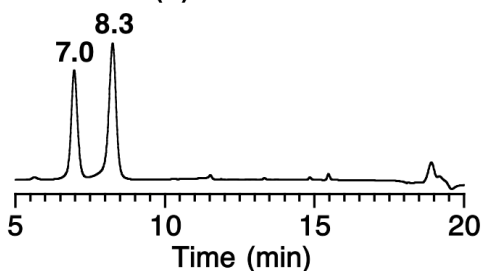

c. Rhodamine-5

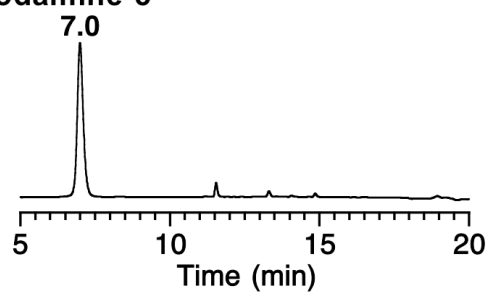

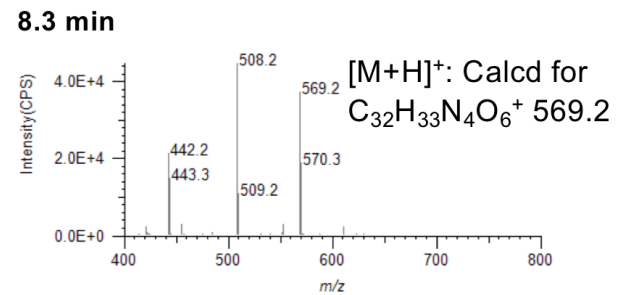

$7.0 \mathrm{~min}$
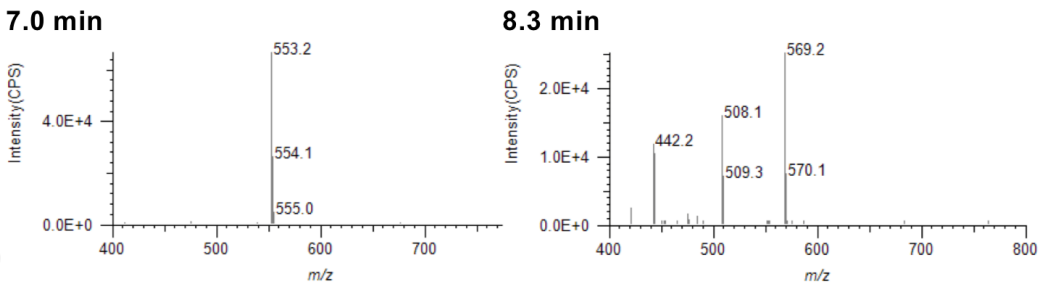

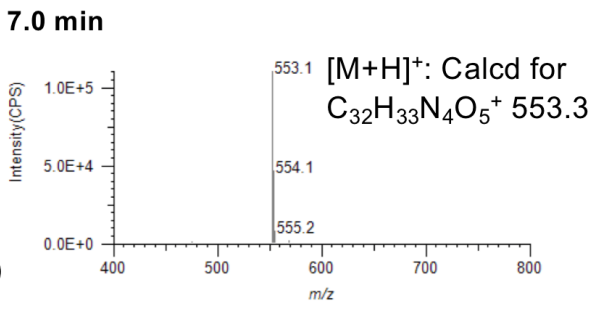

Figure S8. LC-MS analysis of the Fe(II)-triggered deoxygenation reaction of RhoNox-5. HPLC charts of (a) RhoNox-5, (b) the reaction mixture of RhoNox-5 and Fe(II) (2 eq., supplemented as FAS), and (c) Rhodamine-5. The sample concentrations were $100 \mu \mathrm{M}$. The absorbance at $254 \mathrm{~nm}$ was monitored. Mass spectra acquired at the indicated retention times were also shown with the calculated $m / z$. 


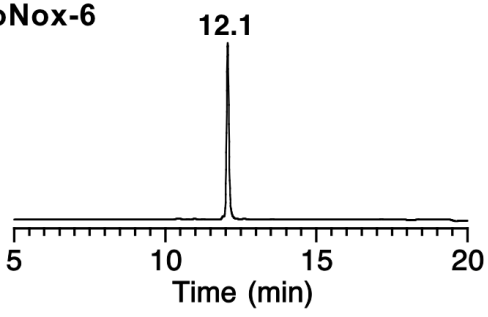

b. RhoNox-6+Fe(II)

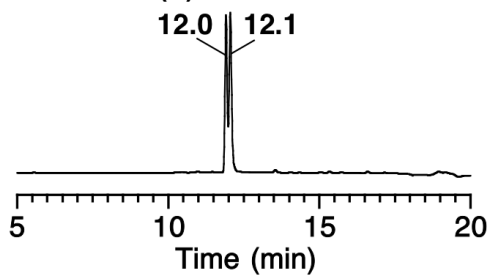

$12.0 \mathrm{~min}$

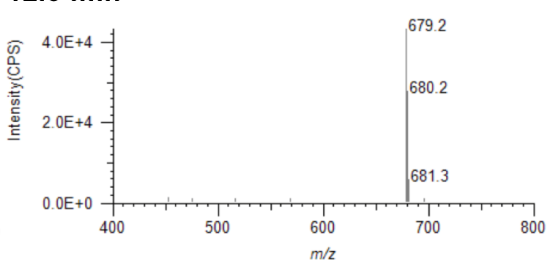

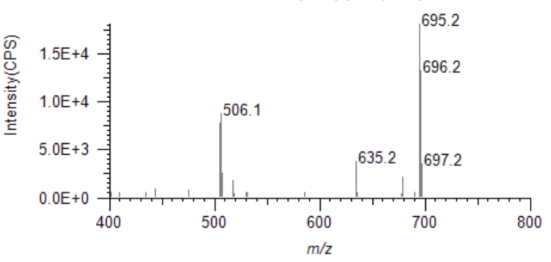

$12.1 \mathrm{~min}$

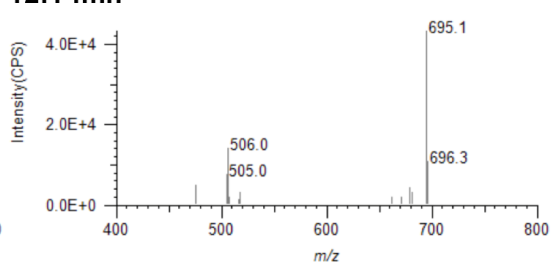

c. Rhodamine- 6
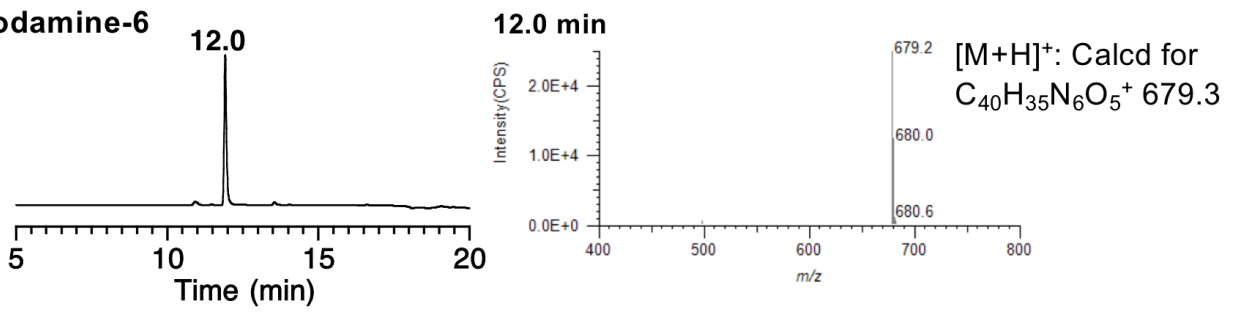

Figure S9. LC-MS analysis of the Fe(II)-triggered deoxygenation reaction of RhoNox-6. HPLC charts of (a) RhoNox-6, (b) the reaction mixture of RhoNox-6 and Fe(II) (2 eq., supplemented as FAS), and (c) Rhodamine-6. The sample concentrations were $100 \mu \mathrm{M}$. The absorbance at $254 \mathrm{~nm}$ was monitored. Mass spectra acquired at the indicated retention times were also shown with the calculated $\mathrm{m} / \mathrm{z}$.

a. RhoNox-7

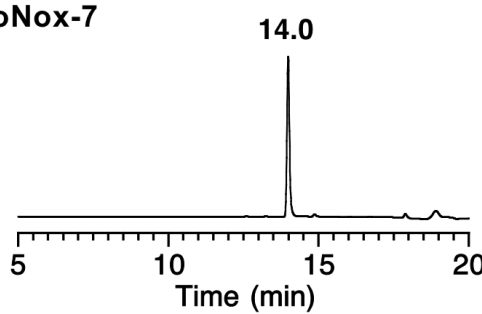

$14.0 \mathrm{~min}$

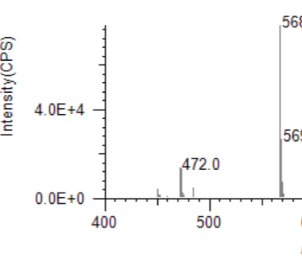

b. RhoNox-7+Fe(II)

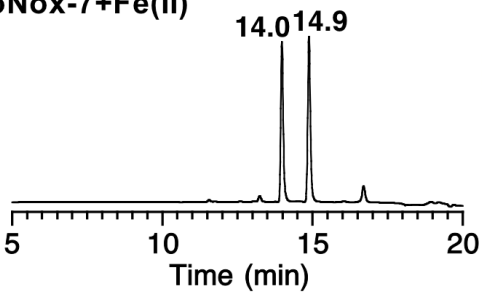

$14.0 \mathrm{~min}$

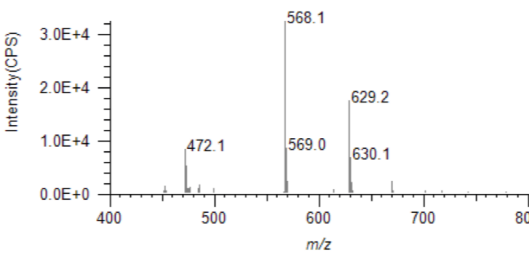

$14.9 \mathrm{~min}$

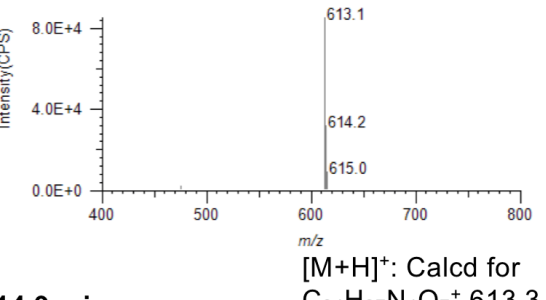

c. Rhodamine-7
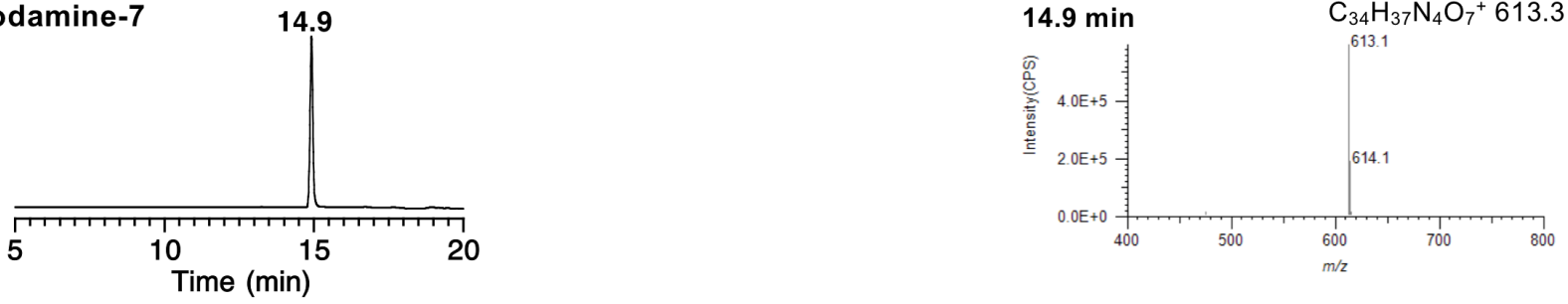

Figure S10. LC-MS analysis of the Fe(II)-triggered deoxygenation reaction of RhoNox-7. HPLC charts of (a) RhoNox-7, (b) the reaction mixture of RhoNox-7 and Fe(II) (2 eq., supplemented as FAS), and (c) Rhodamine-7. The sample concentrations were $100 \mu \mathrm{M}$. The absorbance at $254 \mathrm{~nm}$ was monitored. Mass spectra acquired at the indicated retention times were also shown with the calculated $m / z$. 

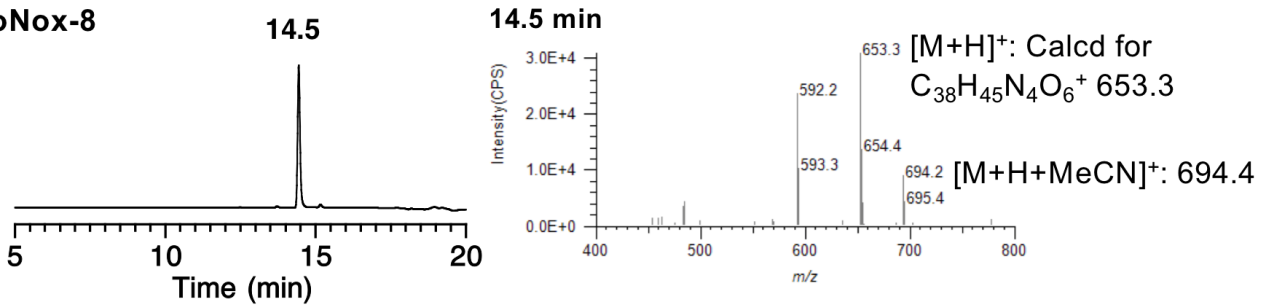

b. RhoNox-8+Fe(II)
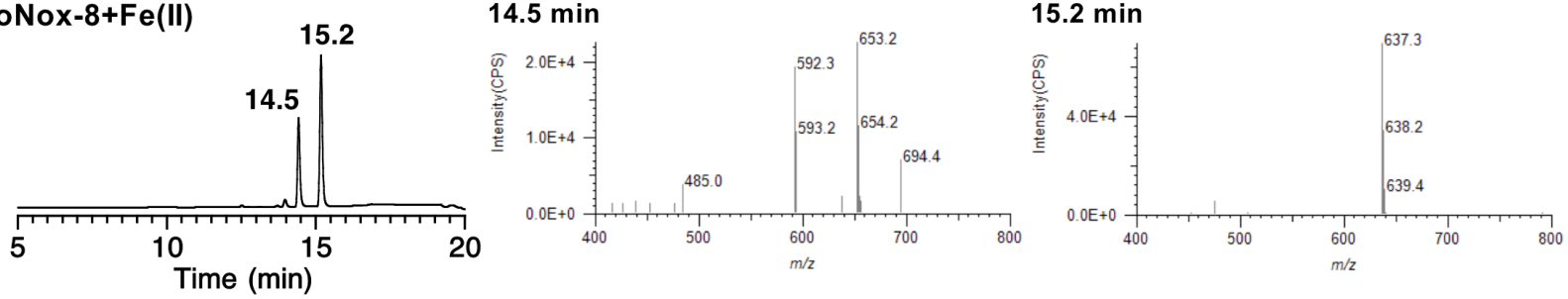

c. Rhodamine-8

15.2
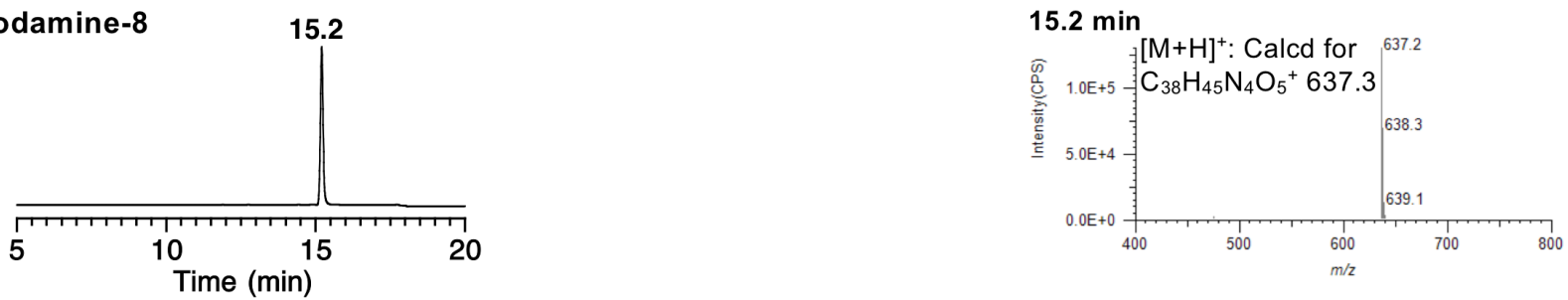

Figure S11. LC-MS analysis of the Fe(II)-triggered deoxygenation reaction of RhoNox-8. HPLC charts of (a) RhoNox-8, (b) the reaction mixture of RhoNox-8 and Fe(II) (2 eq., supplemented as FAS), and (c) Rhodamine- 8 . The sample concentrations were $100 \mu \mathrm{M}$. The absorbance at $254 \mathrm{~nm}$ was monitored. Mass spectra acquired at the indicated retention times were also shown with the calculated $\mathrm{m} / \mathrm{z}$. 


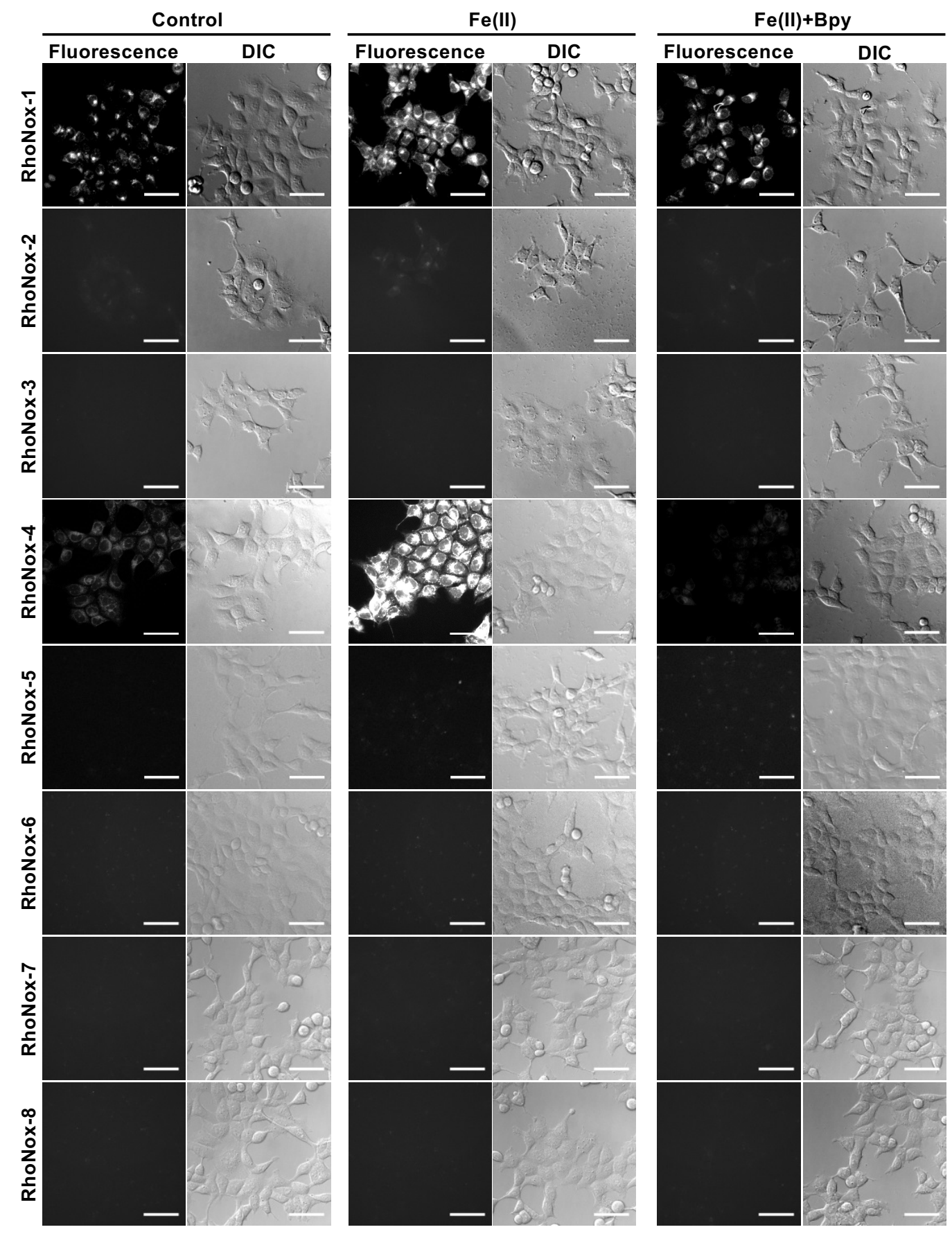

Figure S12. Fluorescence images (Fluorescence) and the corresponding differential interference contrast (DIC) images of HepG2 cells after the incubation with $\mathrm{Fe}(\mathrm{II})(100 \mu \mathrm{M}$, supplemented as FAS) prior to washing with HBSS and staining with RhoNox-N ( $5 \mu \mathrm{M}$ for $\mathrm{N}=1,1 \mu \mathrm{M}$ for $\mathrm{N}=2-8) \pm$ Bpy $(1 \mathrm{mM})$ for 30 min at $37^{\circ} \mathrm{C}$. Scale bars indicate $50 \mu \mathrm{m}$. No detectable fluorescence signals were observed in the cells treated with RhoNox-N $(\mathrm{N}=2,3,5$, 6,7 , and 8 ). 

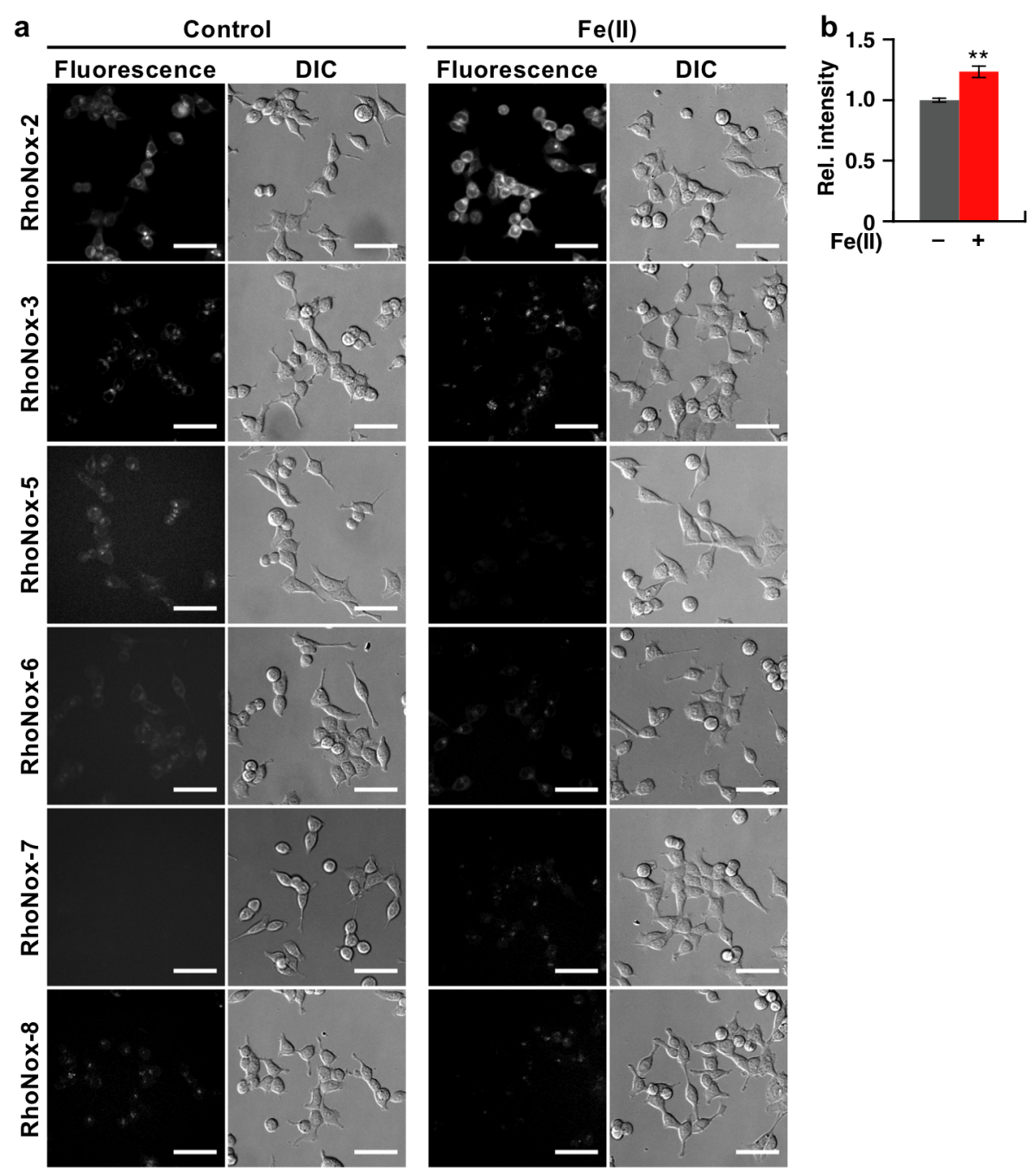

Figure S13. (a) Fluorescence images (Fluorescence) and the corresponding differential interference contrast (DIC) images of HepG 2 cells after the incubation with $\mathrm{Fe}(\mathrm{II})(100 \mu \mathrm{M}$, supplemented as FAS) prior to washing with HBSS and staining with RhoNox-N $(1 \mu \mathrm{M}, \mathrm{N}=2,3,5,6,7$, and 8 , as the mixtures of $1 \%$ Plulonic F-127) for 30 min at $37^{\circ} \mathrm{C}$. Scale bars indicate $50 \mu \mathrm{m}$. (b) The mean fluorescence intensities of the cells that had undergone the following conditions: gray, control; red, FAS $(100 \mu \mathrm{M})$. Error bars are s.e.m. $(\mathrm{n}=5$, approximately 1,200 cells in total were analyzed for each condition). Statistical analysis was performed by Student's $t$-test. ${ }^{* *} P<0.01$. 
$\mathrm{Fe}$ (II)

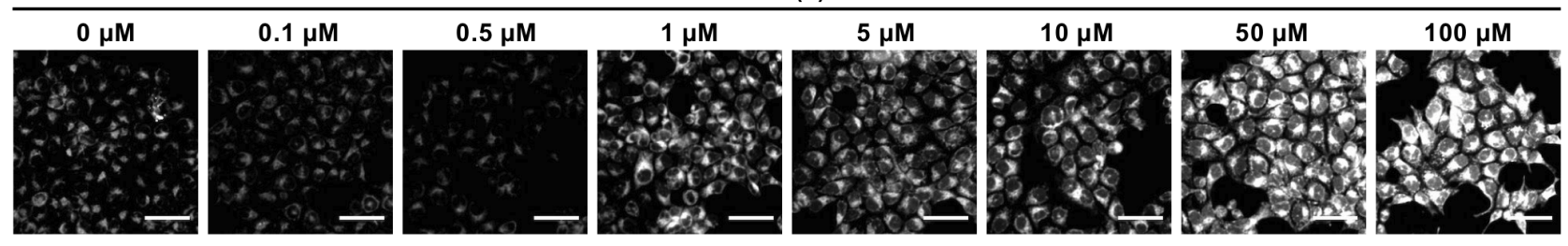

b

Bpy

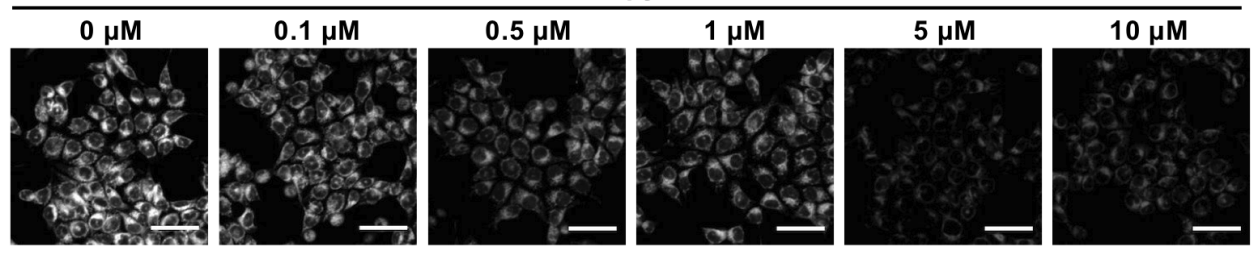

Figure S14. Fluorescence microscopic study of dose-dependency of Fe(II) and Bpy. (a) Representative fluorescence images of HepG2 cells treated with various amount of Fe(II) (supplemented as FAS) for 30 min at $37^{\circ} \mathrm{C}$ prior to washing with HBSS and staining with RhoNox-4 $(1 \mu \mathrm{M})$. (b) Representative fluorescence images of HepG2 cells treated with RhoNox-4 in the presence of various amount of Bpy for 30 min at $37^{\circ} \mathrm{C}$. The graphs for the quantification results are shown in Figure $\mathbf{2 c}$ and $\mathbf{2 d}$.

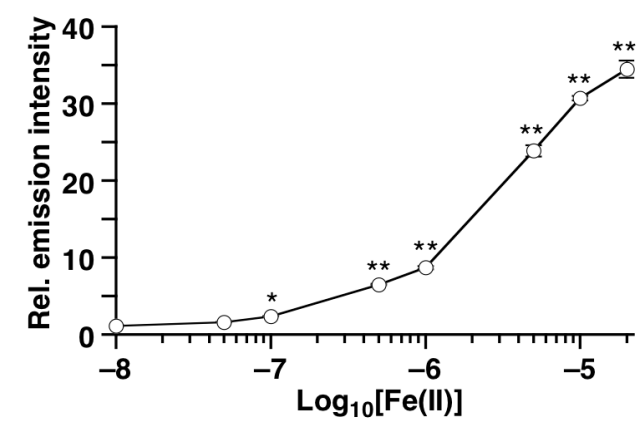

Figure S15. Fluorescence response of RhoNox-4 to various concentrations of $\mathrm{Fe}(\mathrm{II})$ in an aqueous solution. Fluorescence intensities of RhoNox-4 $(2 \mu \mathrm{M})$ after incubation with various concentrations of Fe(II) (supplemented as $\mathrm{FeSO}_{4}$ ) for $1 \mathrm{~h}$ in $50 \mathrm{mM}$ HEPES buffer ( $\mathrm{pH} \mathrm{7.4)}$ at room temperature. The data are mean fluorescence intensity \pm s.e.m $(\mathrm{n}=3) .{ }^{*} P<0.05,{ }^{*} P<0.001$. One-way ANOVA with Dunnett's test versus the control $(0 \mu \mathrm{M}$ Fe(II)).
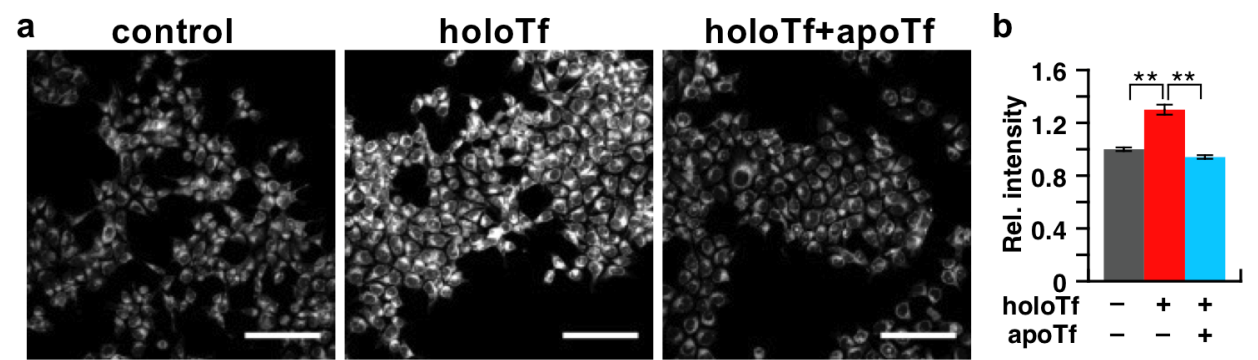

Figure S16. Fluorescence microscopic imaging study for the detection of transferrin-delivered Fe(II). (a) Representative images of HepG2 cells after incubation with holo-transferrin (holoTf, $5 \mu \mathrm{M})$ and holoTf $(5 \mu \mathrm{M})+$ apoTf $(25 \mu \mathrm{M})$ at $37{ }^{\circ} \mathrm{C}$ for 30 min prior to the treatment with RhoNox-4 $(1 \mu \mathrm{M})$ at $37{ }^{\circ} \mathrm{C}$ for 30 min. Scale bars indicate $100 \mu \mathrm{m}$. (b) Quantification of the data. Bars indicate mean fluorescence intensities \pm s.e.m. ${ }^{* *} P<0.001(\mathrm{n}$ $=5$, total ca.1,200 cells were analyzed). Statistical analysis was performed by Students' $t$-test. 

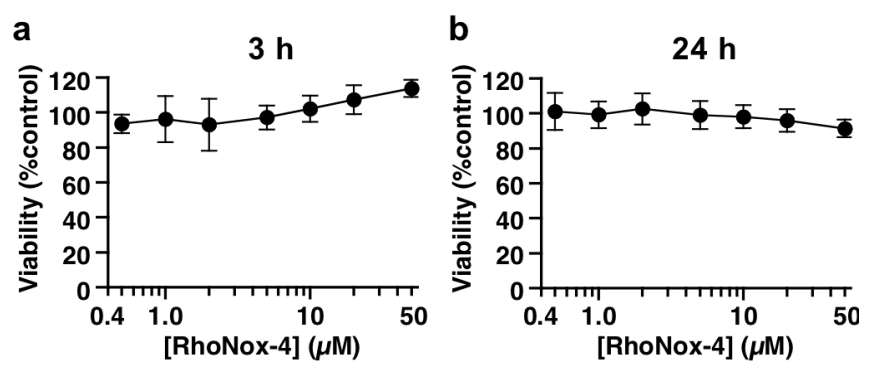

Figure S17. Cytotoxicity assay of RhoNox-4 (MTT assay). (a) Cytotoxicity test of RhoNox-4 toward HepG2 cells after incubation for $3 \mathrm{~h}$ at $37^{\circ} \mathrm{C}$. (b) Cytotoxicity test of RhoNox-4 toward HepG2 cells after incubation for $24 \mathrm{~h}$ at $37^{\circ} \mathrm{C}$. No significant change was observed. $(\mathrm{n}=8)$ Error bars indicate \pm s.e.m. Statistical analysis was performed by Students' $t$-test.

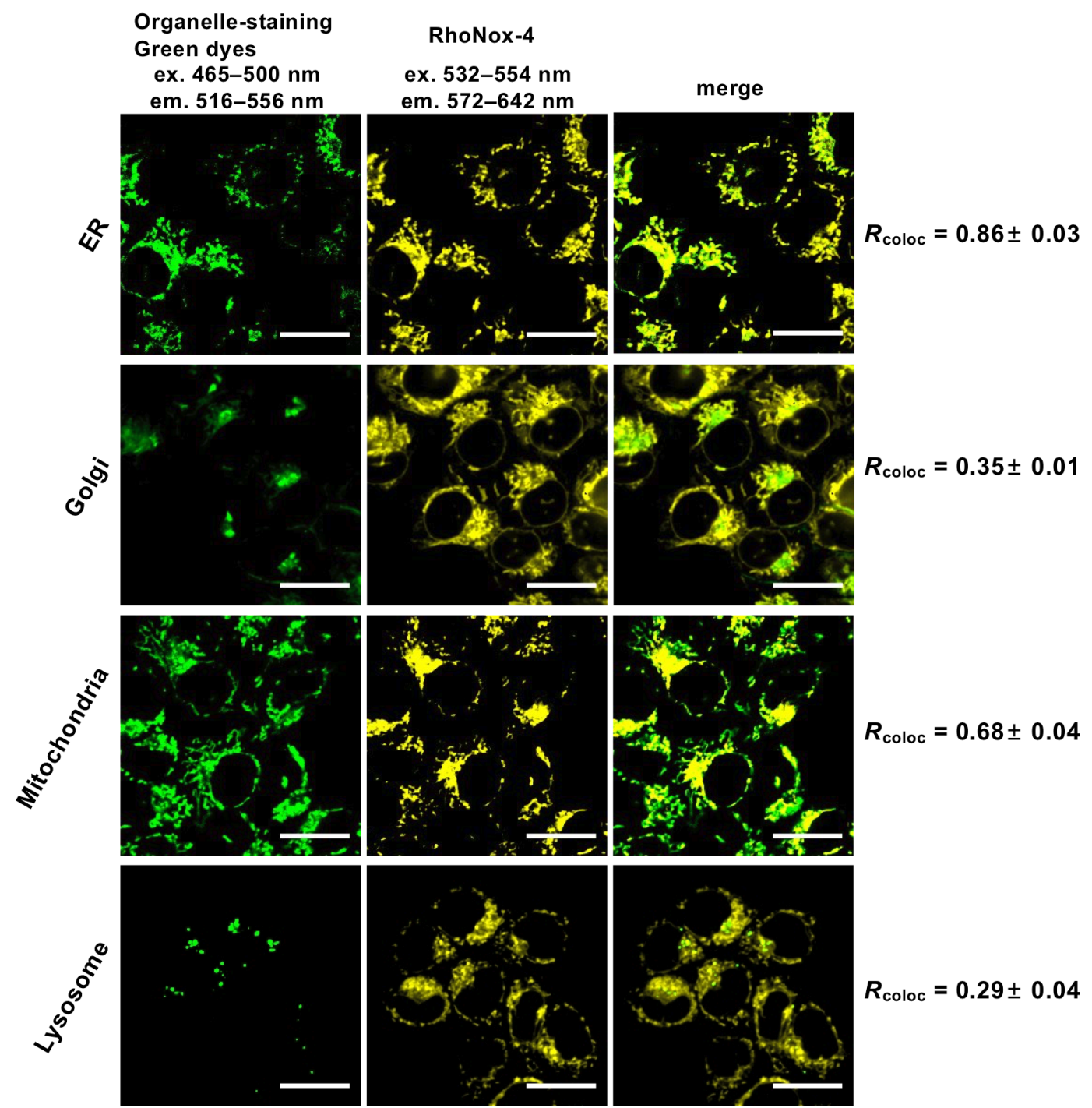

Figure S18. Co-localization assay by fluorescence microscopy. Representative images HepG2 cells treated with RhoNox-4 $(1 \mu \mathrm{M})$ the indicated fluorescent organelle indicators, ER-Tracker Green (ER), BODIPY-FL-ceramide BSA complex (Golgi), MitoTracker Green (mitochondria), and LysoTracker Green-DND (lysosome). (Left column) Images of the organelle staining dye acquired by green channel. (Middle column) Images from RhoNox4. (Right column) Merged images of the green and RhoNox-4 channels. Scale bars are $20 \mu \mathrm{m}$. Pearson's correlation values $\left(R_{\text {coloc }}\right)$ were calculated for ca.150 cells each. The cells were pre-treated with Fe(II) $(100 \mu \mathrm{M}$, supplemented as FAS) for $30 \mathrm{~min}$ at $37^{\circ} \mathrm{C}$ prior to the staining. 


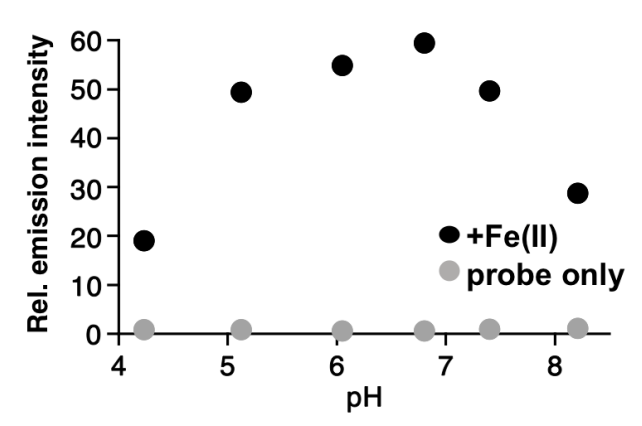

Figure S19. Fluorescence response of RhoNox-4 $(2 \mu \mathrm{M})$ to $\mathrm{Fe}(\mathrm{II})(100 \mu \mathrm{M})$ at $\mathrm{pH}=4.2,5.1,6.1,6.8,7.4$, and 8.3. Black and gray dots indicate the fluorescence intensities after the reaction with and without $\mathrm{Fe}(\mathrm{II})(1 \mathrm{~h}$, room temperature), respectively.
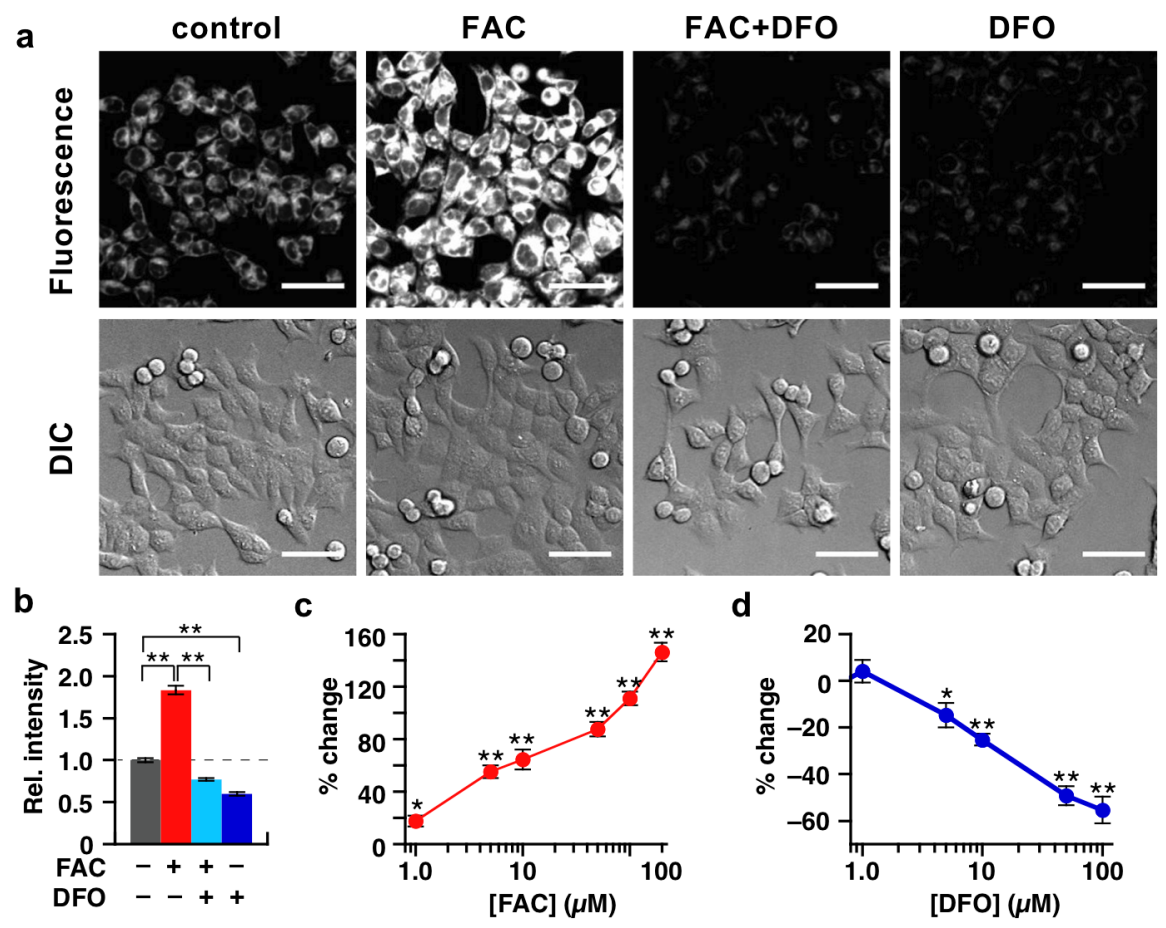

Figure S20. Fluorescence microscopic imaging study for evaluation of ferric ammonium citrate (FAC) and deferoxamine (DFO) as the positive and negative control compounds for the high throughput screening. (a) Representative fluorescence (upper) and DIC (lower) images of HepG2 cells after treatment with FAC (100 $\mu \mathrm{M})$, FAC $(100 \mu \mathrm{M})+$ DFO $(100 \mu \mathrm{M})$, and DFO $(100 \mu \mathrm{M})$ for $30 \mathrm{~min}$ at $37^{\circ} \mathrm{C}$ followed by washing with HBSS and staining with RhoNox-4 $(1 \mu \mathrm{M})$ at $37^{\circ} \mathrm{C}$ for $30 \mathrm{~min}$. Scale bars indicate $100 \mu \mathrm{m}$. (b) Quantification of the data. Bars indicate mean fluorescence intensities \pm s.e.m. ${ }^{*} P<0.001$ ( $\mathrm{n}=5$, total ca. 1,200 cells were analyzed). Statistical analysis was performed by Students' $t$-test. (c,d) Fluorescence intensities of the HepG2 cells treated with the various concentrations of (c) FAC and (d) DFO, which was detected by RhoNox-4. Plots indicate \%change from control \pm s.e.m. ${ }^{*} P<0.05,{ }^{* *} P<0.001$ ( $\mathrm{n}=8$, total ca., 600 cells were analyzed). Statistical analysis was performed by oneway ANOVA with Dunnett's test versus the control. 


\begin{tabular}{|l|lrrrrrrrrrrrr|r|r|}
\hline & & 1 & 2 & 3 & 4 & 5 & 6 & 7 & 8 & 9 & 10 & 11 & 12 \\
\hline A & bkg & 0 & 0 & 0 & 0 & 0 & 0 & 0 & 0 & 0 & 0 Control \\
B & bkg & 0.2 & 0.5 & 1 & 2 & 5 & 10 & 20 & 50 & 100 & 200 Control \\
\hline C & bkg & 200 & 100 & 50 & 20 & 10 & 5 & 2 & 1 & 0.5 & 0.2 Control \\
\hline D & bkg & 200 & 200 & 200 & 200 & 200 & 200 & 200 & 200 & 200 & 200 Control \\
\hline E & DFO & 0 & 0 & 0 & 0 & 0 & 0 & 0 & 0 & 0 & 0 & 200 \\
F & DFO & 0.2 & 0.5 & 1 & 2 & 5 & 10 & 20 & 50 & 100 & 200 & 200 \\
G & DFO & 200 & 100 & 50 & 20 & 10 & 5 & 2 & 1 & 0.5 & 0.2 & 200 \\
H & DFO & 200 & 200 & 200 & 200 & 200 & 200 & 200 & 200 & 200 & 200 & 200 \\
\hline
\end{tabular}

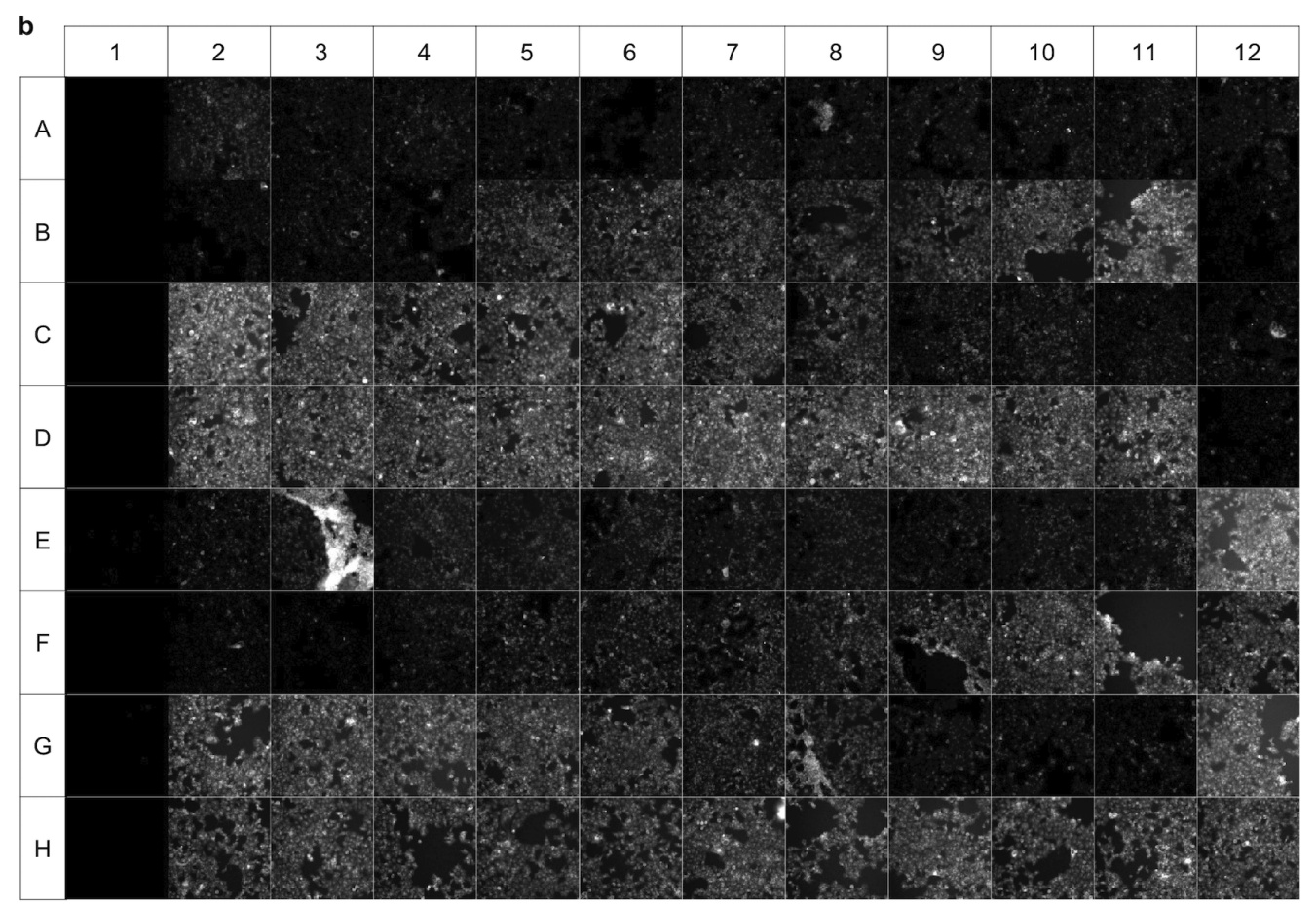

c
\begin{tabular}{|l|rrrrrrrrrrrrrr|r|r|}
\hline & 1 & 2 & 3 & 4 & 5 & 6 & 7 & 8 & 9 & 10 & 11 & 12 \\
\hline A & -0.991 & 0.198 & 0.077 & -0.023 & -0.022 & -0.061 & -0.086 & 0.042 & -0.031 & -0.074 & 0.063 & 0.090 \\
B & -0.998 & -0.026 & -0.028 & 0.066 & 0.245 & 0.366 & 0.446 & 0.566 & 0.647 & 0.884 & 1.085 & -0.111 \\
C & -1.003 & 1.462 & 1.325 & 1.093 & 0.843 & 0.704 & 0.819 & 0.459 & 0.166 & 0.206 & 0.089 & -0.001 \\
D & -1.009 & 1.166 & 1.265 & 1.160 & 1.184 & 1.456 & 1.287 & 1.565 & 1.537 & 1.528 & 1.571 & 0.022 \\
E & -0.493 & 0.041 & & 0.118 & 0.019 & 0.150 & 0.039 & 0.127 & 0.058 & 0.122 & 0.090 & 1.462 \\
F & -0.551 & -0.075 & 0.005 & 0.027 & 0.530 & 0.533 & 0.665 & 0.715 & 0.912 & 1.182 & 1.589 & 1.185 \\
G & -0.532 & 1.372 & 1.314 & 1.073 & 1.225 & 1.020 & 0.663 & 0.606 & 0.280 & 0.231 & 0.061 & 1.832 \\
H & -0.530 & 1.127 & 1.112 & 0.961 & 1.061 & 1.093 & 1.083 & 1.000 & 1.103 & 1.331 & 1.190 & 0.978 \\
\hline
\end{tabular}

Figure S21. Microplate-based analysis of labile Fe(II) in HepG2 cells by a high-content imaging system for the detection of dose dependency of Fe(II). (a) Plate layout for 96-well-based high-content imaging. HepG2 cells (seeded in a 96-well plate) were treated with the indicated concentrations of FAC $(0-200 \mu \mathrm{M})$ or DFO $(100 \mu \mathrm{M})$ for $3 \mathrm{~h}$ at $37^{\circ} \mathrm{C}$ and then incubated with RhoNox-4 $(1 \mu \mathrm{M})$ after washing. Control and bkg mean $0 \mu \mathrm{M}$ of FAC and background (no cell). (b) Montage of the acquired fluorescence images at each well. (c) Quantification of the fluorescence signals inside cells. The numbers are fluorescence changes $\left(F / F_{0}-1\right)$ from control, where $F$ and $F_{0}$ indicate mean fluorescence intensities at each well and the mean fluorescence intensity of the control cells (well\# A12-D12). 
[DFO] $(\mu \mathrm{M})$

\begin{tabular}{|c|c|c|c|c|c|c|c|c|c|c|c|c|}
\hline & 1 & 2 & 3 & 4 & 5 & 6 & 5 & 8 & 9 & 10 & 11 & 12 \\
\hline$A$ & none & none & none & none & none & none & none & none & none & none & none & none \\
\hline B & none & none & 0.0 & 0.5 & 1 & 2 & 5 & 10 & 20 & 50 & 100 & none \\
\hline C & none & none & 0.0 & 0.5 & 1 & 2 & 5 & 10 & 20 & 50 & 100 & none \\
\hline$D$ & none & none & 0.0 & 0.5 & 1 & 2 & 5 & 10 & 20 & 50 & 100 & none \\
\hline E & none & none & 0.0 & 0.5 & 1 & 2 & 2 & 10 & 20 & 50 & 100 & none \\
\hline$F$ & none & none & 0.0 & 0.5 & 1 & 2 & 2 & 10 & 20 & 50 & 100 & none \\
\hline$G$ & none & none & 0.0 & 0.5 & 1 & 2 & 2 & 10 & 20 & 50 & 100 & none \\
\hline $\mathrm{H}$ & none & none & none & none & none & none & none & none & none & none & none & none \\
\hline
\end{tabular}

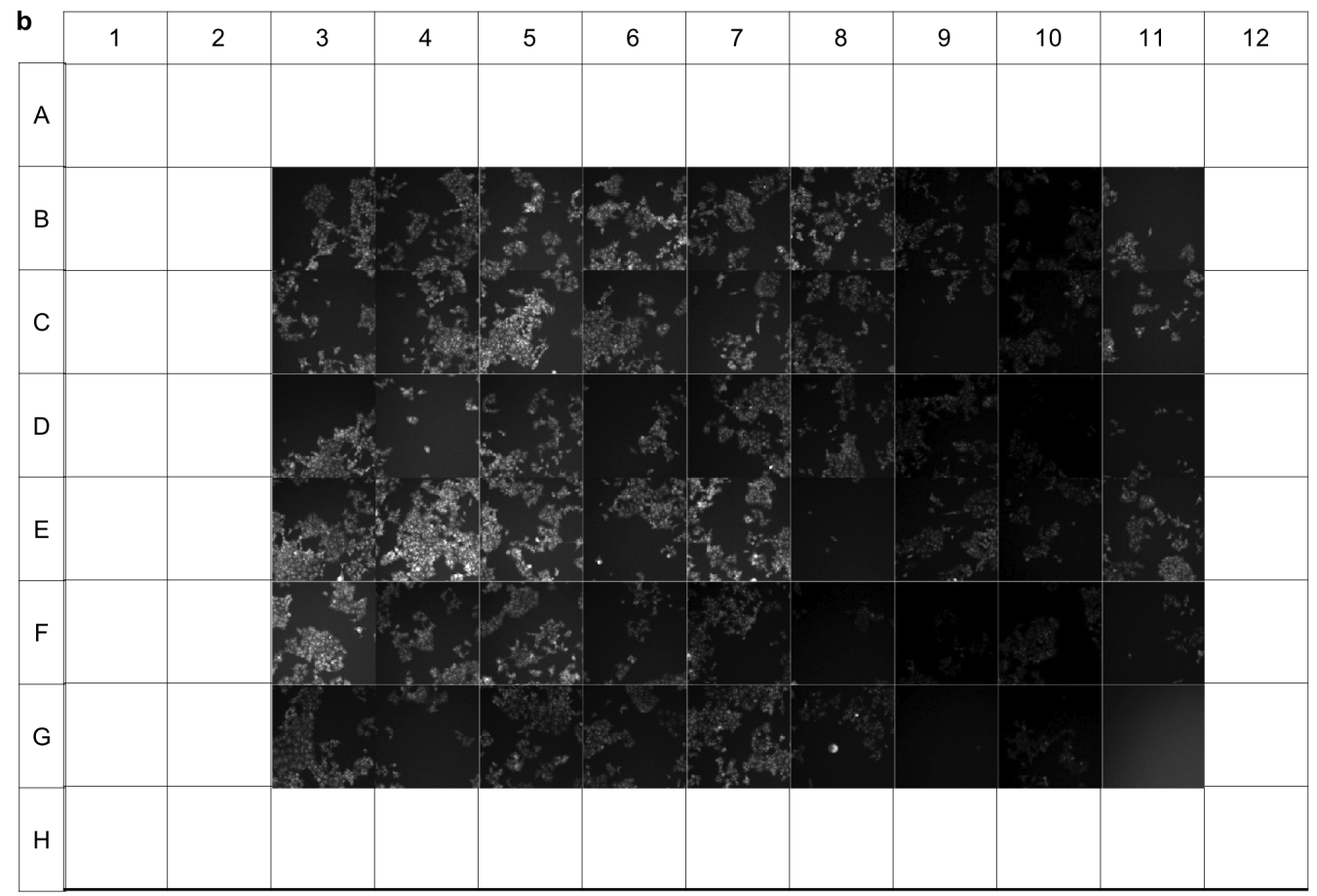

\begin{tabular}{|c|c|c|c|c|c|c|c|c|c|c|c|c|}
\hline & \multicolumn{12}{|c|}{$\left(F / F_{\text {control }}\right)-1$} \\
\hline & 1 & & 3 & 4 & 5 & 6 & 7 & 8 & 9 & 10 & 11 & 1 \\
\hline A & $n / a$ & $n / a$ & $\mathrm{n} / \mathrm{a}$ & $n / a$ & $n / a$ & $\mathrm{n} / \mathrm{a}$ & $n / a$ & $n / a$ & $n / a$ & $n / a$ & $n / a$ & $n / a$ \\
\hline B & $n / a$ & $n / a$ & -0.181 & -0.286 & -0.141 & -0.212 & -0.310 & -0.442 & -0.152 & -0.845 & $\mid-0.792$ & $n / a$ \\
\hline C & $n / a$ & $\mathrm{n} / \mathrm{a}$ & 0.180 & -0.200 & -0.047 & -0.216 & -0.491 & -0.296 & -0.222 & -0.696 & -0.732 & $n / a$ \\
\hline D & $n / a$ & $n / a$ & -0.023 & -0.341 & -0.266 & 0.100 & -0.663 & -0.449 & -0.362 & -0.689 & \begin{tabular}{|l|}
-0.793 \\
\end{tabular} & $n / a$ \\
\hline E & $n / a$ & $n / a$ & 0.182 & -0.238 & -0.001 & 0.106 & -0.376 & -0.457 & -0.432 & -0.629 & -0.410 & $n / a$ \\
\hline F & $n / a$ & $n / a$ & -0.175 & -0.107 & -0.269 & -0.091 & -0.259 & -0.487 & -0.560 & -0.876 & -0.655 & $n / a$ \\
\hline G & $n / a$ & $\mathrm{n} / \mathrm{a}$ & 0.017 & -0.255 & -0.114 & -0.288 & -0.095 & -0.345 & -0.538 & -0.555 & \begin{tabular}{|l|}
-0.862 \\
\end{tabular} & $n / a$ \\
\hline $\mathrm{H}$ & $n / a$ & $\mathrm{n} / \mathrm{a}$ & $\mathrm{n} / \mathrm{a}$ & $n / a$ & $n / a$ & $\mathrm{n} / \mathrm{a}$ & $n / a$ & $n / a$ & $n / a$ & $n / a$ & $n / a$ & $n / a$ \\
\hline
\end{tabular}

Figure S22. Microplate-based analysis of labile Fe(II) in HepG2 cells by a high-content imaging system for the detection of dose dependency of DFO. (a) Plate layout for 96-well-based high-content imaging. HepG2 cells (seeded in a 96-well plate) were treated with the indicated concentrations of DFO for $3 \mathrm{~h}$ at $37^{\circ} \mathrm{C}$ and then incubated with RhoNox-4 $(1 \mu \mathrm{M})$ after washing. Control and bkg mean $0 \mu \mathrm{M}$ FAC and background (no cell). (b) Montage of the acquired fluorescence images at each well. (c) Quantification of the fluorescence signals inside cells. The numbers are fluorescence changes $\left(F / F_{\text {control }}-1\right)$ from control, where $F$ and $F_{\text {control }}$ indicate mean fluorescence intensities at each well and the mean fluorescence intensity of the control cells (well\# C3-F3). 


\begin{tabular}{|l|r|r|r|r|r|r|r|r|r|r|r|r|r|r|r|}
\hline & & 1 & 2 & 3 & 4 & 5 & 6 & 7 & 8 & 9 & 10 & 11 & 12 \\
\hline A & bkg & Cmpd & Cmpd & Cmpd & Cmpd & Cmpd & Cmpd & Cmpd & Cmpd & Cmpd & Cmpd Control \\
B & bkg & Cmpd & Cmpd & Cmpd & Cmpd & Cmpd & Cmpd & Cmpd & Cmpd & Cmpd & Cmpd Control \\
\hline C & bkg & Cmpd & Cmpd & Cmpd & Cmpd & Cmpd & Cmpd & Cmpd & Cmpd & Cmpd & Cmpd Control \\
D & bkg & Cmpd & Cmpd & Cmpd & Cmpd & Cmpd & Cmpd & Cmpd & Cmpd & Cmpd & Cmpd Control \\
\hline E & DFO & Cmpd & Cmpd & Cmpd & Cmpd & Cmpd & Cmpd & Cmpd & Cmpd & Cmpd & Cmpd FAC \\
\hline F & DFO & Cmpd & Cmpd & Cmpd & Cmpd & Cmpd & Cmpd & Cmpd & Cmpd & Cmpd & Cmpd FAC \\
\hline G & DFO & Cmpd & Cmpd & Cmpd & Cmpd & Cmpd & Cmpd & Cmpd & Cmpd & Cmpd & Cmpd FAC \\
\hline H & DFO & Cmpd & Cmpd & Cmpd & Cmpd & Cmpd & Cmpd & Cmpd & Cmpd & Cmpd & Cmpd FAC \\
\hline
\end{tabular}

Figure S23. Plate layout for the screening. Cmpd and bkg indicate sample compounds and background, respectively. $F$ and $F_{0}$ indicate mean fluorescence intensities at each well and the mean fluorescence intensity of the control cells (well\# A12-D12).
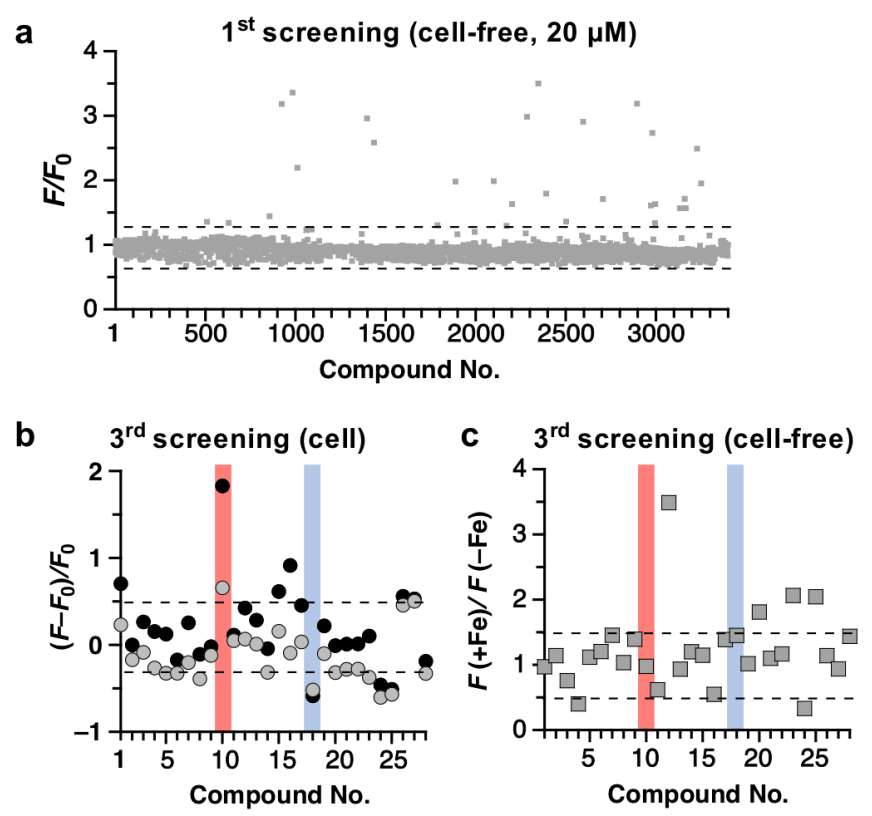

Figure S24. High-throughput screening of labile iron fluctuating compounds ( $1^{\text {st }}$ and $3^{\text {rd }}$ screening). (a) Plot of mean relative fluorescence intensities $\left(F / F_{0}, \mathrm{n}=3\right)$ acquired from the mixed samples of each compound $(20 \mu \mathrm{M})$ and RhoNox-4 $(1 \mu \mathrm{M})$ without cells. $F$ and $F_{0}$ indicate mean fluorescence intensities at each well and the mean fluorescence intensity of the control cells (well\# A12-D12, Figure S22) (b) Plot of mean fluorescence intensity changes $\left(F / F_{0}-1, \mathrm{n}=3\right)$ acquired from the cells treated with the compounds (black: $10 \mu \mathrm{M}$, gray: $\left.5 \mu \mathrm{M}\right) . F$ and $F_{0}$ indicate mean fluorescence intensity of each well and the mean fluorescence intensity of the control cells, respectively. (c) Plot of mean relative fluorescence intensities $(F(+\mathrm{Fe}) / F(-\mathrm{Fe}), \mathrm{n}=3)$ acquired from the mixed samples of each compound $(10 \mu \mathrm{M})$ and RhoNox-4 $(1 \mu \mathrm{M})$ in the presence or absence of $\mathrm{Fe}(\mathrm{II})(10 \mu \mathrm{M}$, supplemented as $\left.\mathrm{FeSO}_{4}\right)$ without cells. $F(+\mathrm{Fe})$ and $F(-\mathrm{Fe})$ indicate mean fluorescence intensities in the presence and absence of $\mathrm{Fe}(\mathrm{II})$, respectively. The compound numbers of positive and negative hits are highlighted by red and blue, respectively. Compound \#10 is the final hit compound, lomofungin. 


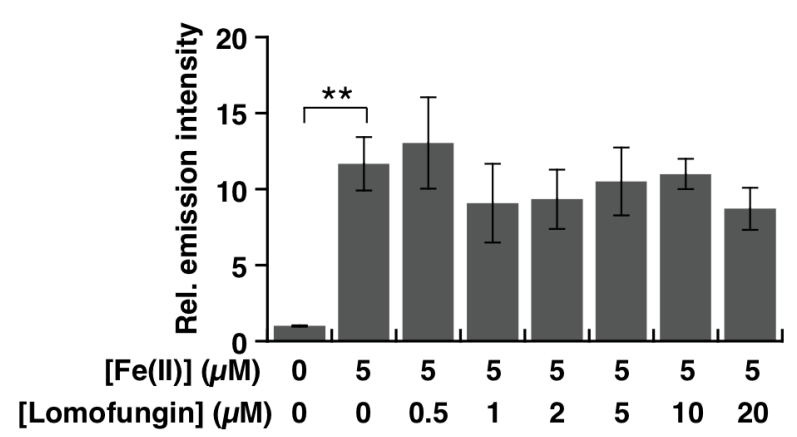

Figure S25. Effect of lomofungin on the fluorescence response of RhoNox-4 toward Fe(II) in cuvettes. Plot of mean relative fluorescence response of RhoNox-4 to $\mathrm{Fe}$ (II) $\left(5 \mu \mathrm{M}\right.$, supplemented as $\left.\mathrm{FeSO}_{4}\right)$ in the presence of various concentrations of lomofungin in $50 \mathrm{mM}$ HEPES buffer, $\mathrm{pH}$ 7.4). Bars are mean fluorescence intensity \pm s.e.m. $(\mathrm{n}=3)$ of $580-640 \mathrm{~nm}\left(\lambda_{\mathrm{ex}}=520 \mathrm{~nm}\right) .{ }^{* *} P<0.001(\mathrm{n}=3)$. Statistical analysis was performed by one-way ANOVA with Dunnett's test versus Fe(II) $(5 \mu \mathrm{M})$ only.
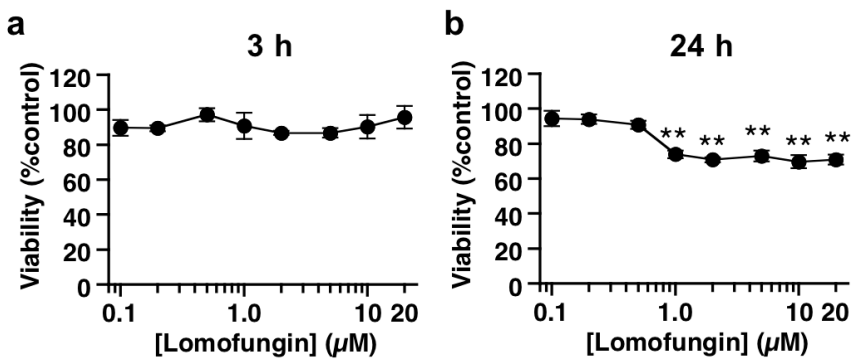

Figure S26. Cytotoxicity assay of lomofungin (MTT assay). Viability (\%control) of the cells treated with various concentrations of lomofungin at $37^{\circ} \mathrm{C}$ for (a) $3 \mathrm{~h}$ and (b) $24 \mathrm{~h}$. Error bars indicate \pm s.e.m. ${ }^{* *} P<0.001(\mathrm{n}=4)$. Statistical analysis was performed by one-way ANOVA with Dunnett's test versus control.

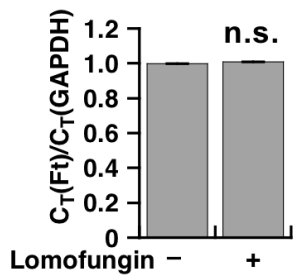

Figure S27. qRT-PCR analysis of $m$ RNA levels of ferritin of HepG2 cells treated with or without lomofungin (20 $\mu \mathrm{M})$. Error bars indicate \pm s.e.m., and n.s. means not significant. $(\mathrm{n}=4)$. Statistical analysis was performed by Students' $t$-test. 
${ }^{1}$ H-NMR and ${ }^{13} \mathrm{C}$-NMR spectra of the newly synthesized compounds

RhoNox-2 $\left(\mathrm{CD}_{3} \mathrm{OD}, 500 \mathrm{MHz}\right)$

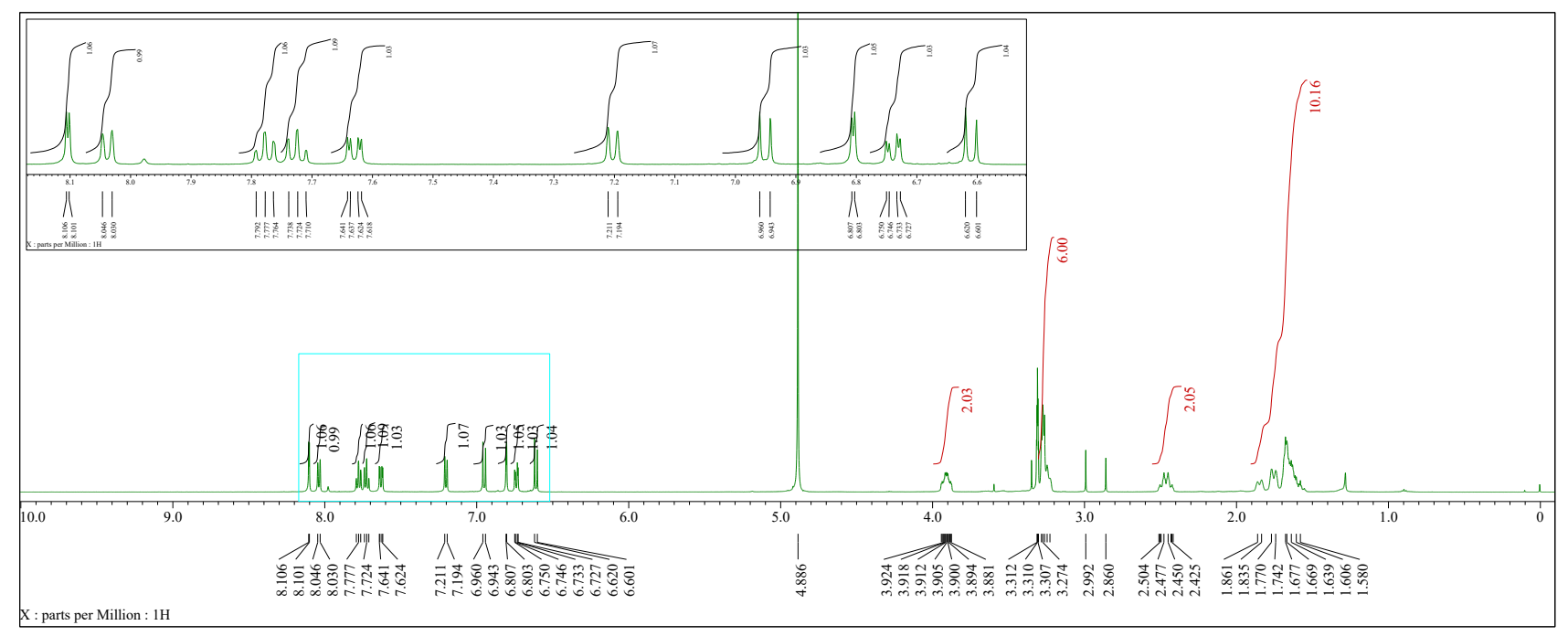

RhoNox-2 ( $\left.\mathrm{CD}_{3} \mathrm{OD}, 125 \mathrm{MHz}\right)$

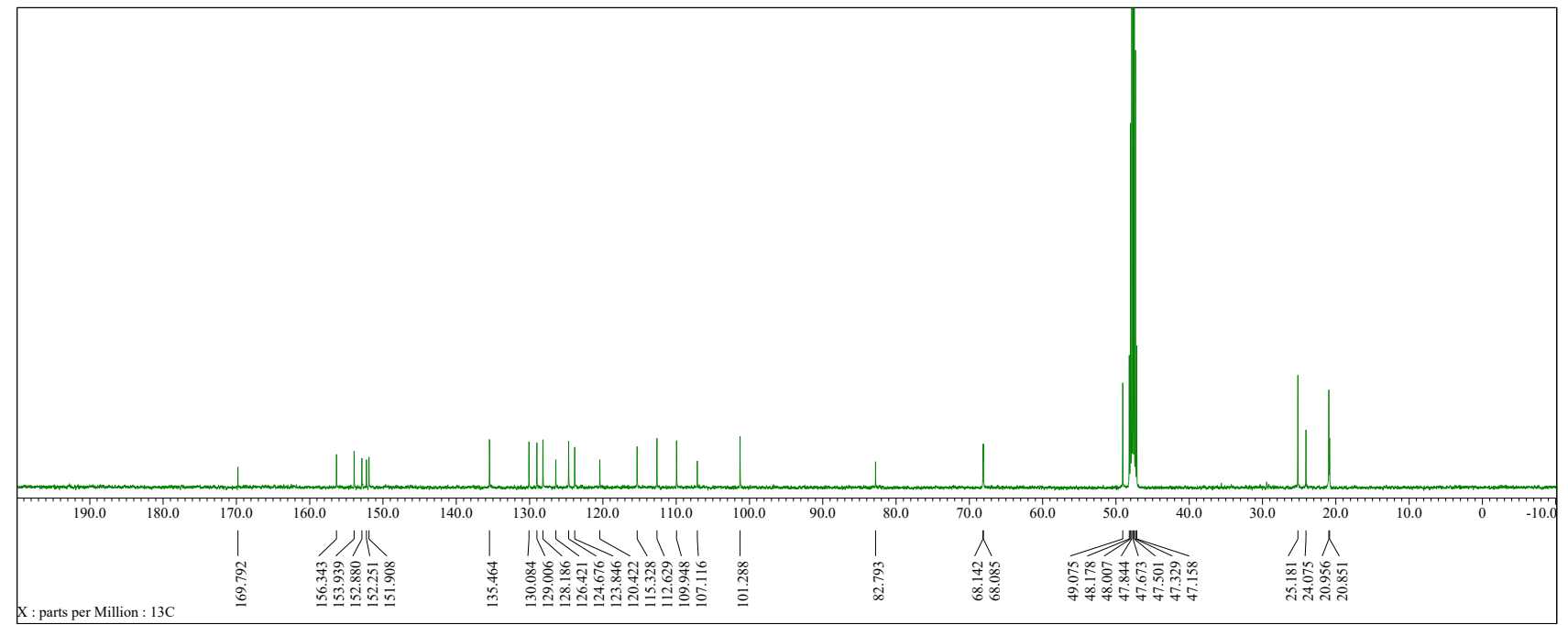


RhoNox-3 $\left(\mathrm{CD}_{3} \mathrm{OD}, 500 \mathrm{MHz}\right)$

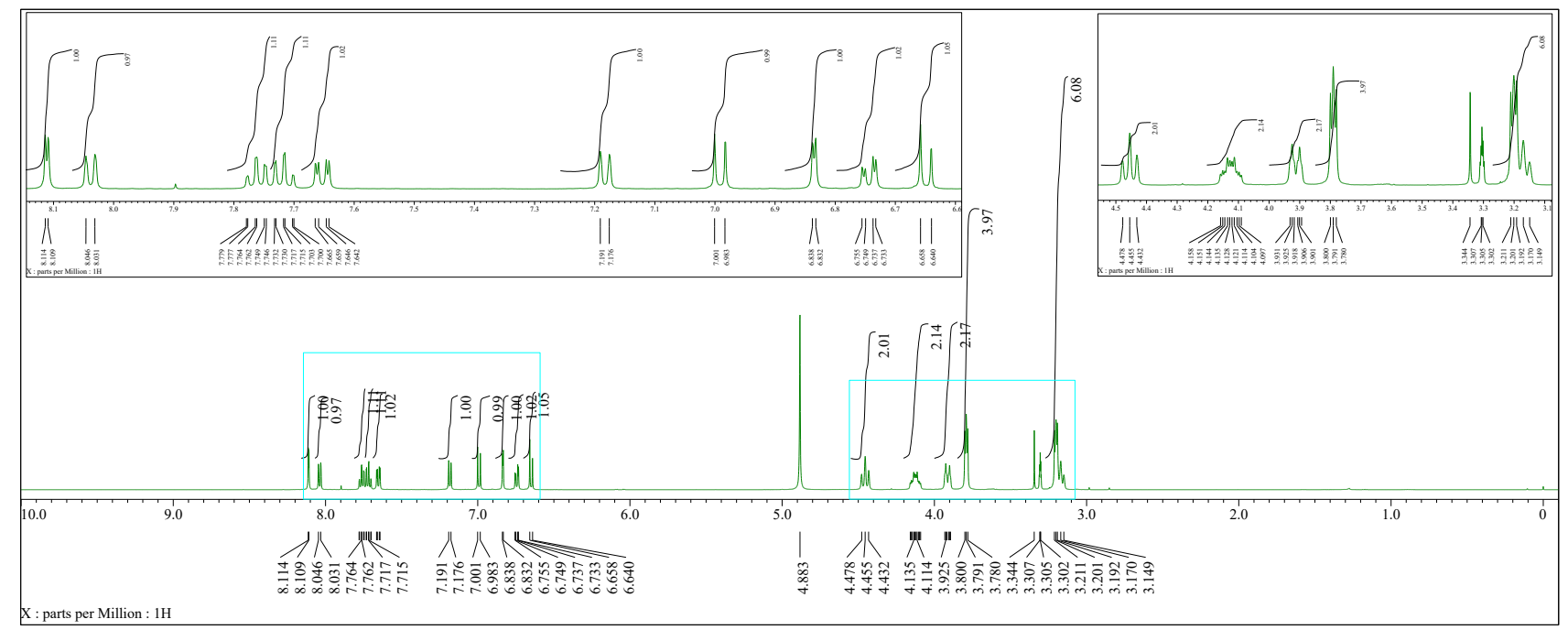

RhoNox-3 ( $\left.\mathrm{CD}_{3} \mathrm{OD}, 125 \mathrm{MHz}\right)$

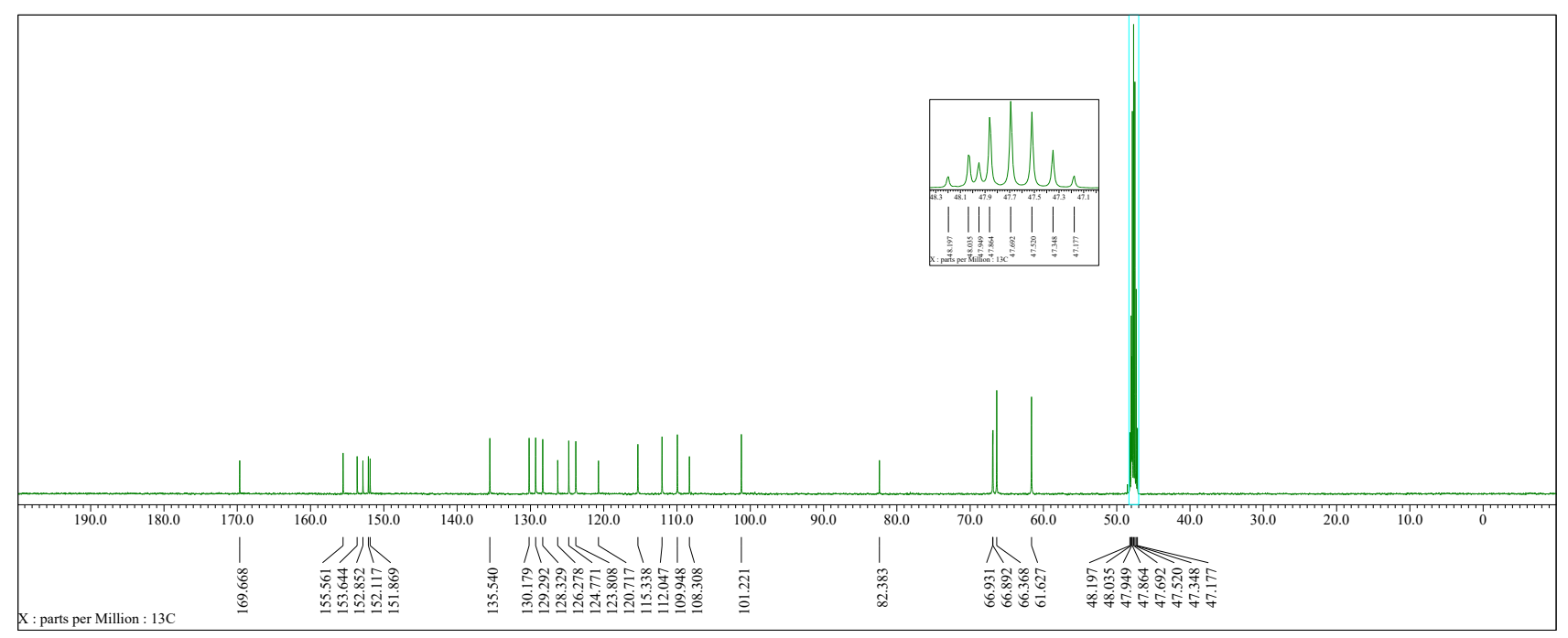


RhoNox-4 ( $\left.\mathrm{CD}_{3} \mathrm{OD}, 500 \mathrm{MHz}\right)$

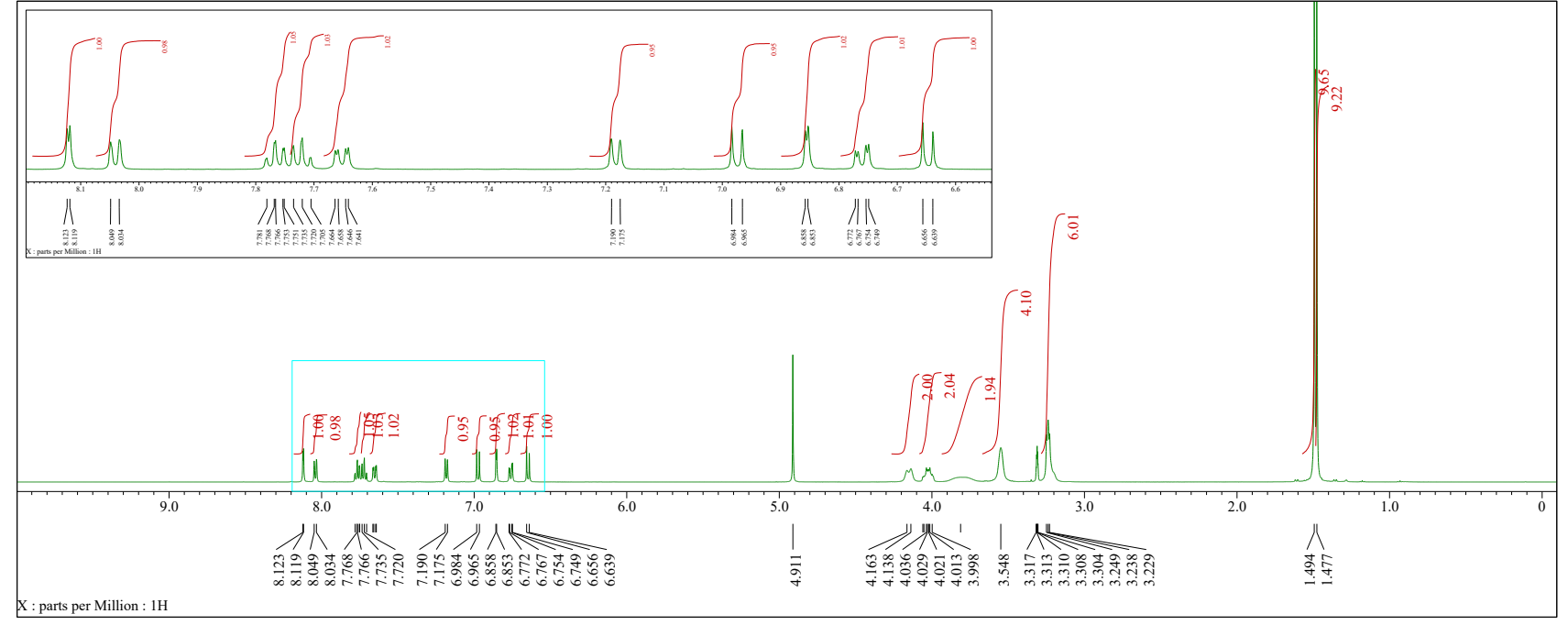

RhoNox-4 (CD $\left.{ }_{3} \mathrm{OD}, 125 \mathrm{MHz}\right)$

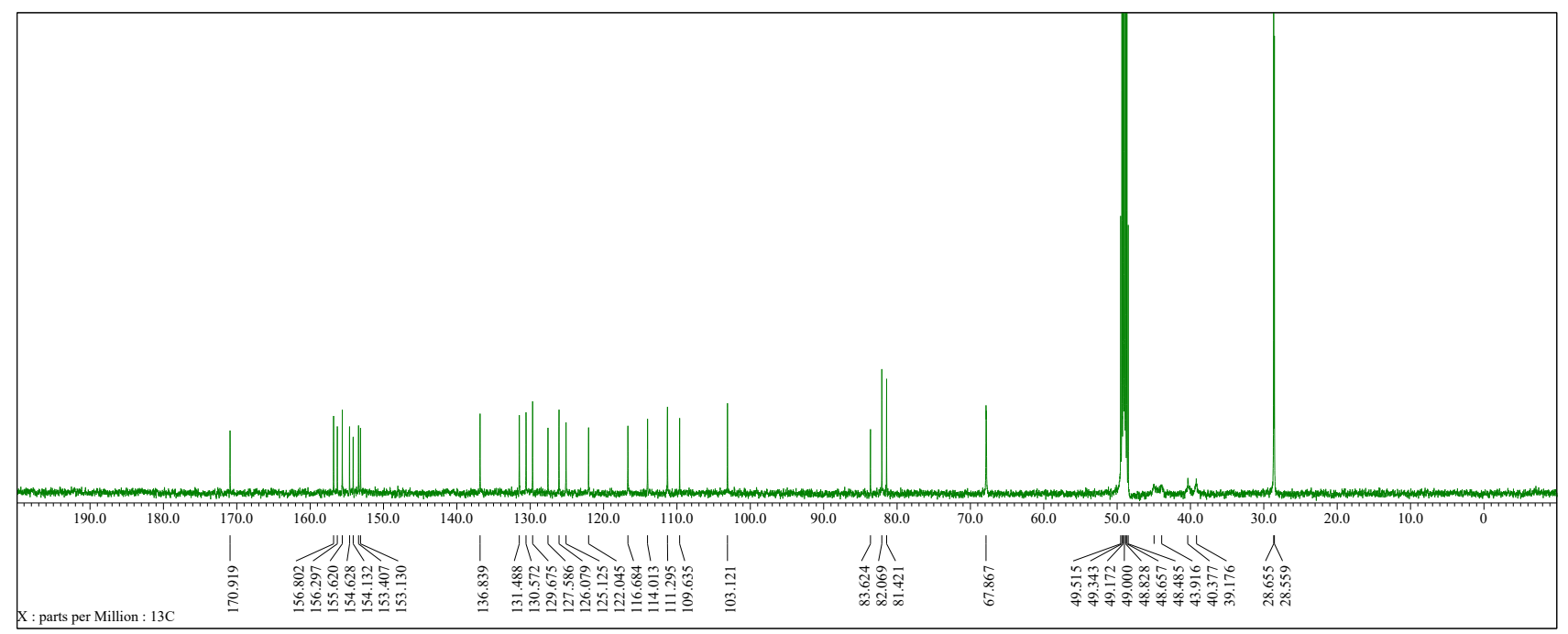


Rhodamine-5 $\left(\mathrm{CDCl}_{3}, 400 \mathrm{MHz}\right)$

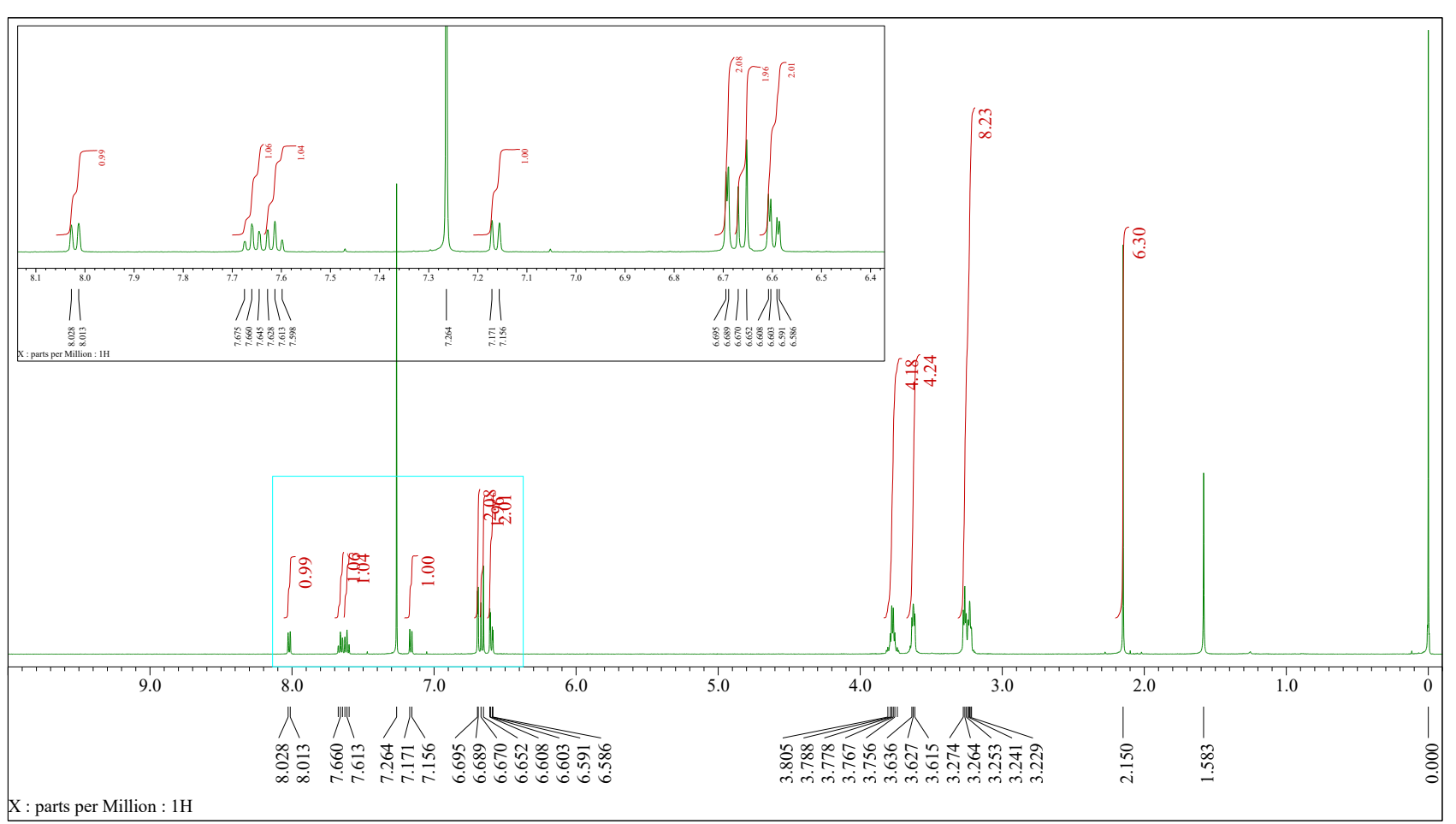

Rhodamine-5 $\left(\mathrm{CDCl}_{3}, 100 \mathrm{MHz}\right)$

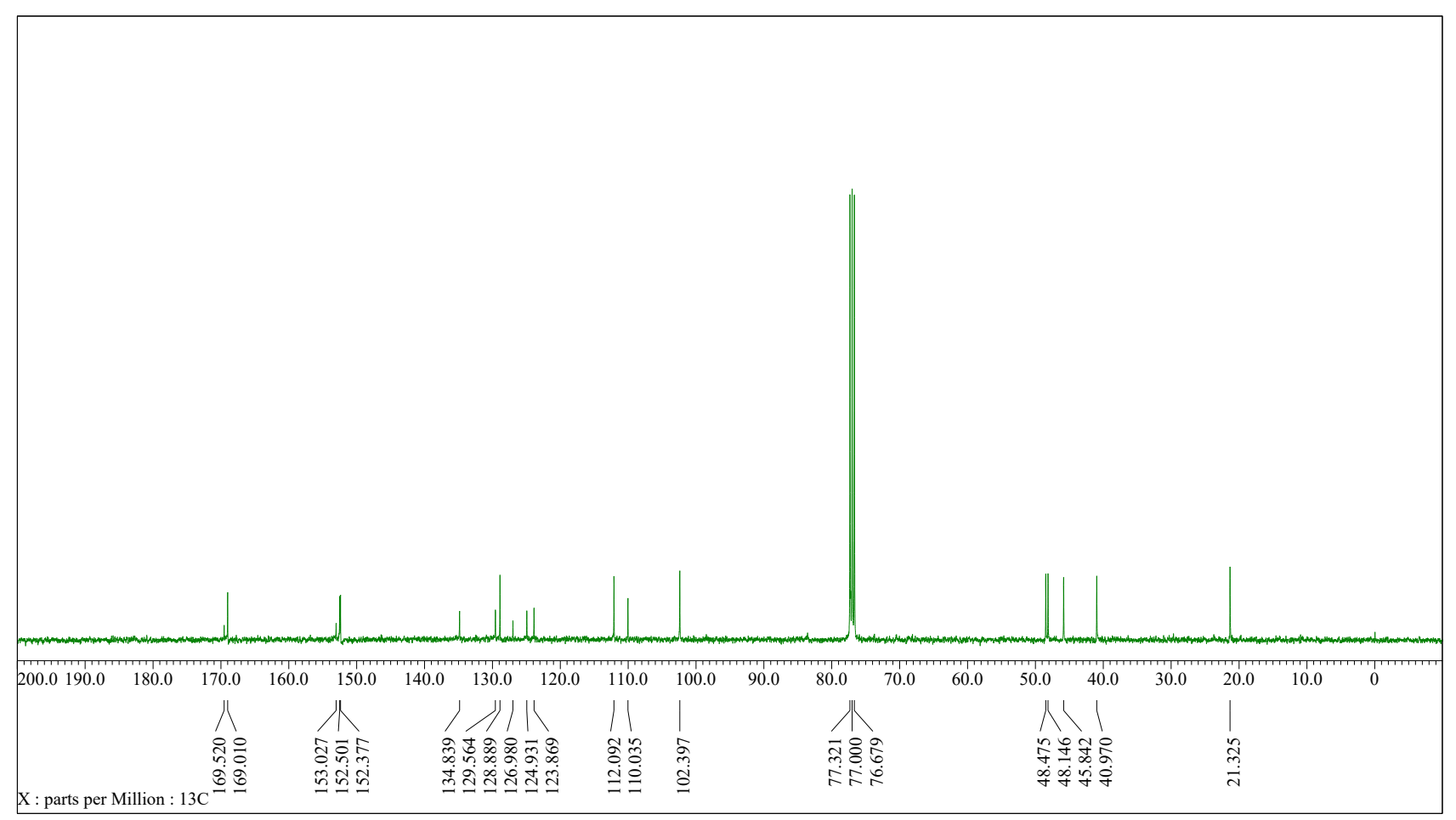


RhoNox-5 ( $\left.\mathrm{CD}_{3} \mathrm{OD}, 500 \mathrm{MHz}\right)$

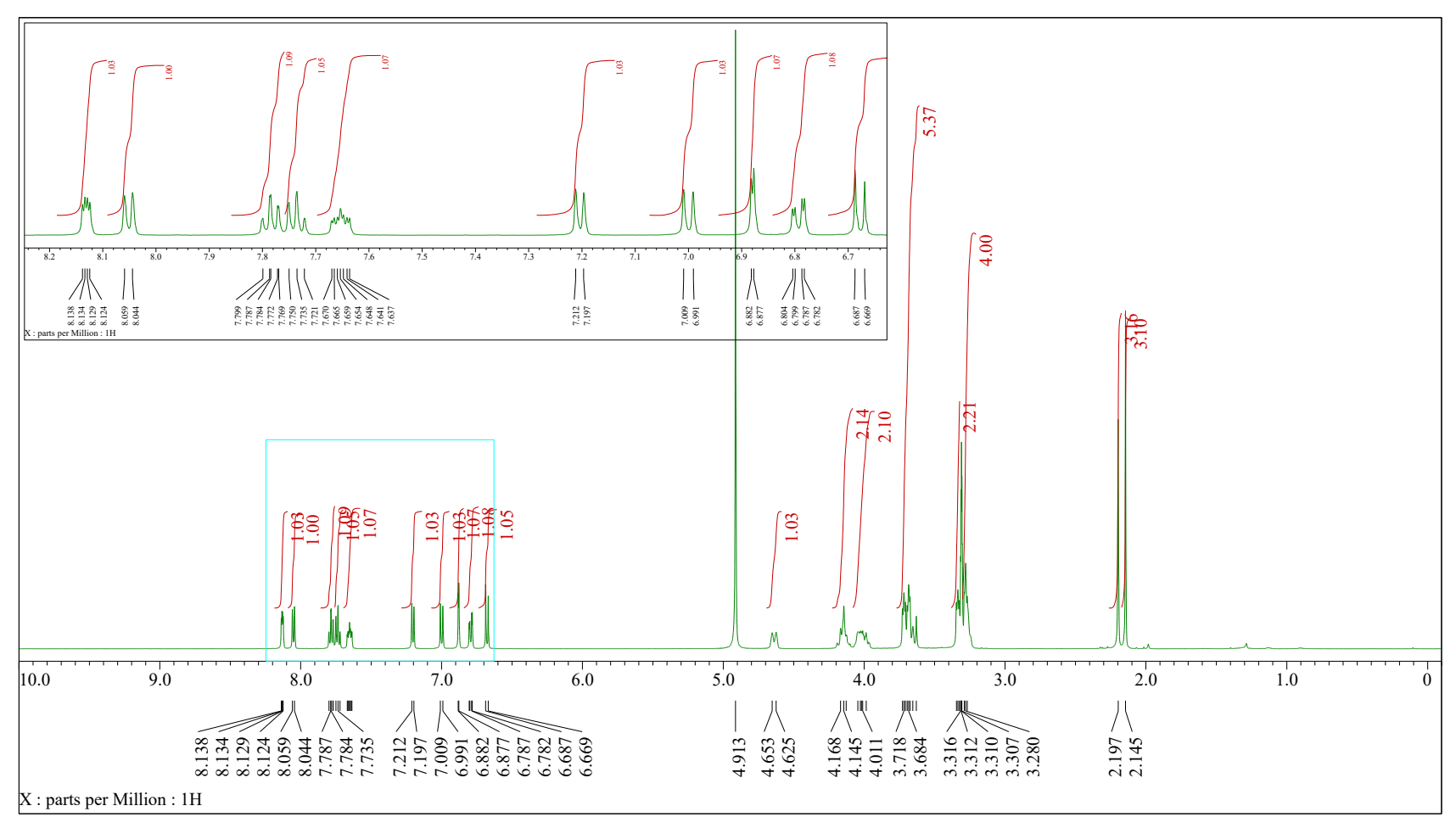

RhoNox-5 ( $\left.\mathrm{CD}_{3} \mathrm{OD}, 125 \mathrm{MHz}\right)$

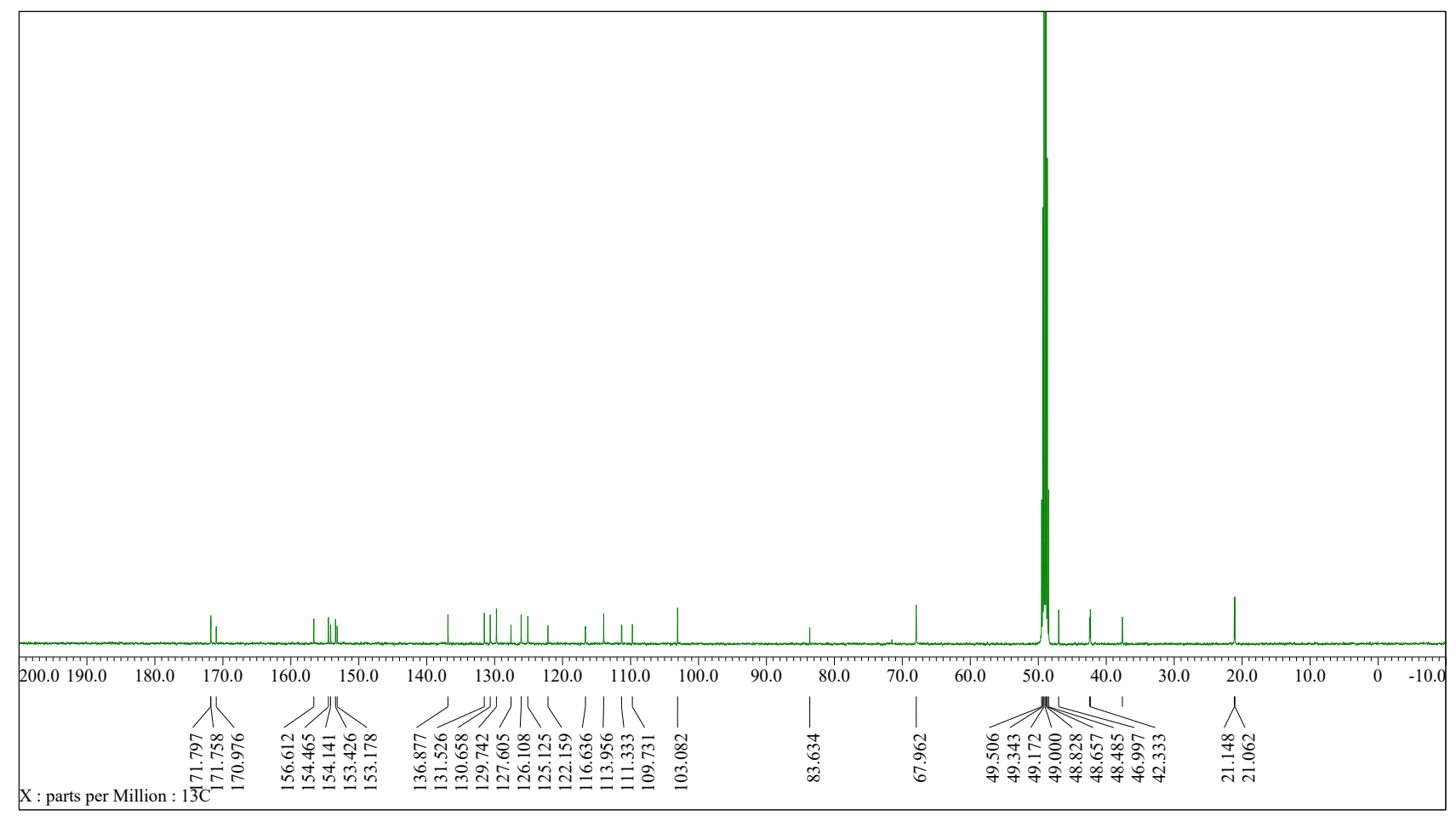


Rhodamine-6 $\left(\mathrm{CDCl}_{3}, 500 \mathrm{MHz}\right)$

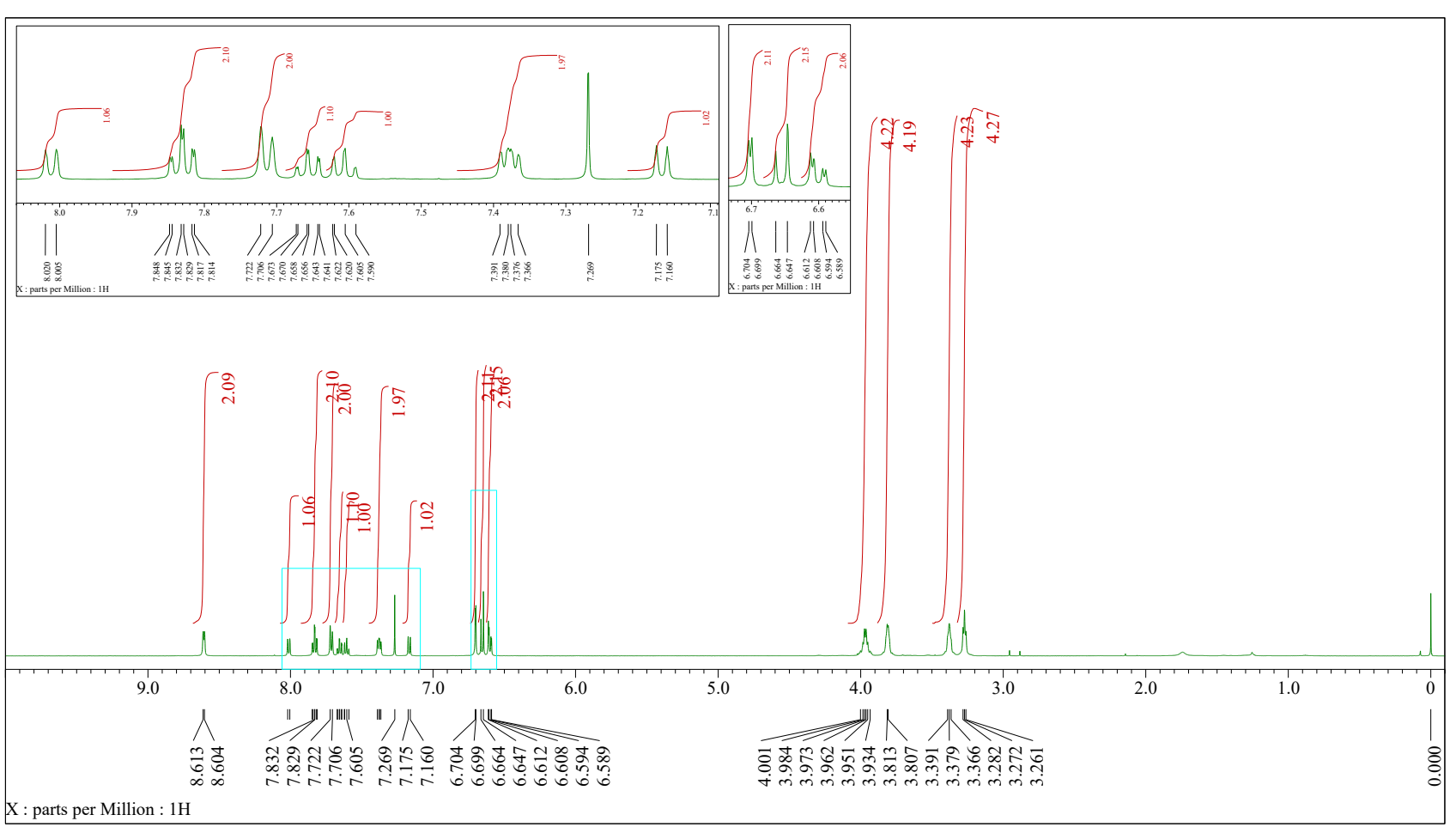

Rhodamine-6 $\left(\mathrm{CDCl}_{3}, 100 \mathrm{MHz}\right)$

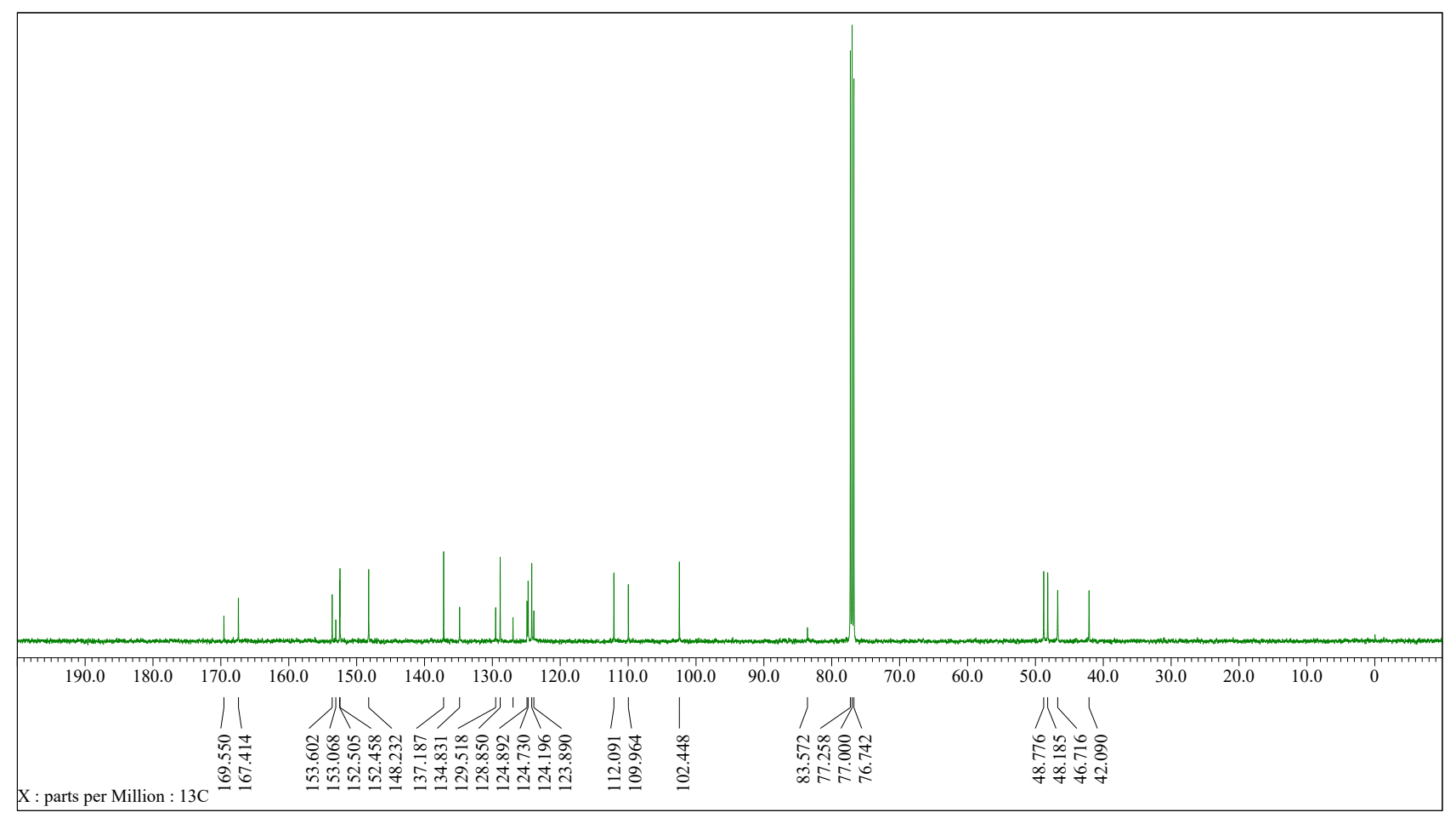


RhoNox-6 ( $\left.\mathrm{CD}_{3} \mathrm{OD}, 500 \mathrm{MHz}\right)$

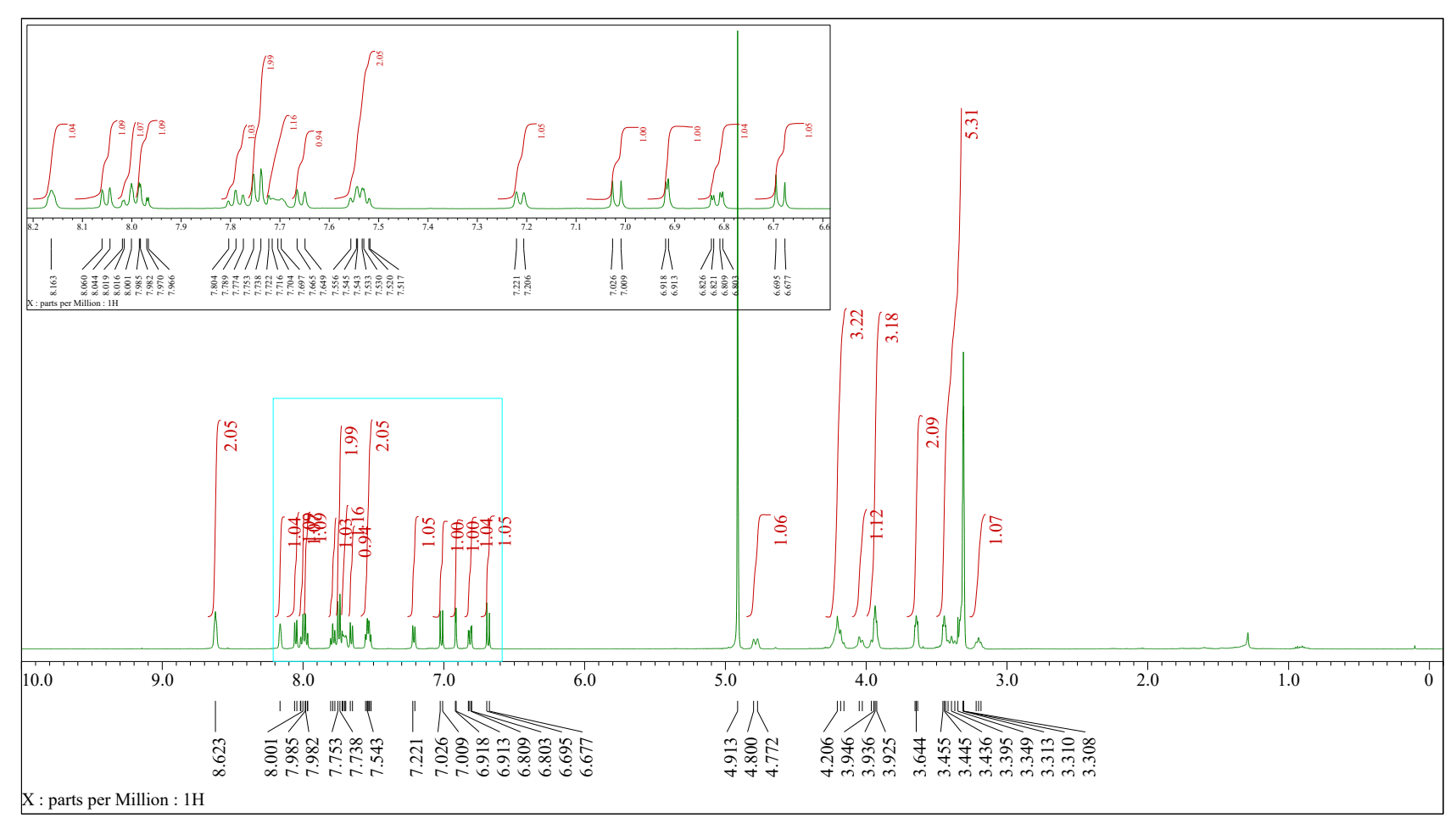

RhoNox-6 ( $\left.\mathrm{CD}_{3} \mathrm{OD}, 125 \mathrm{MHz}\right)$

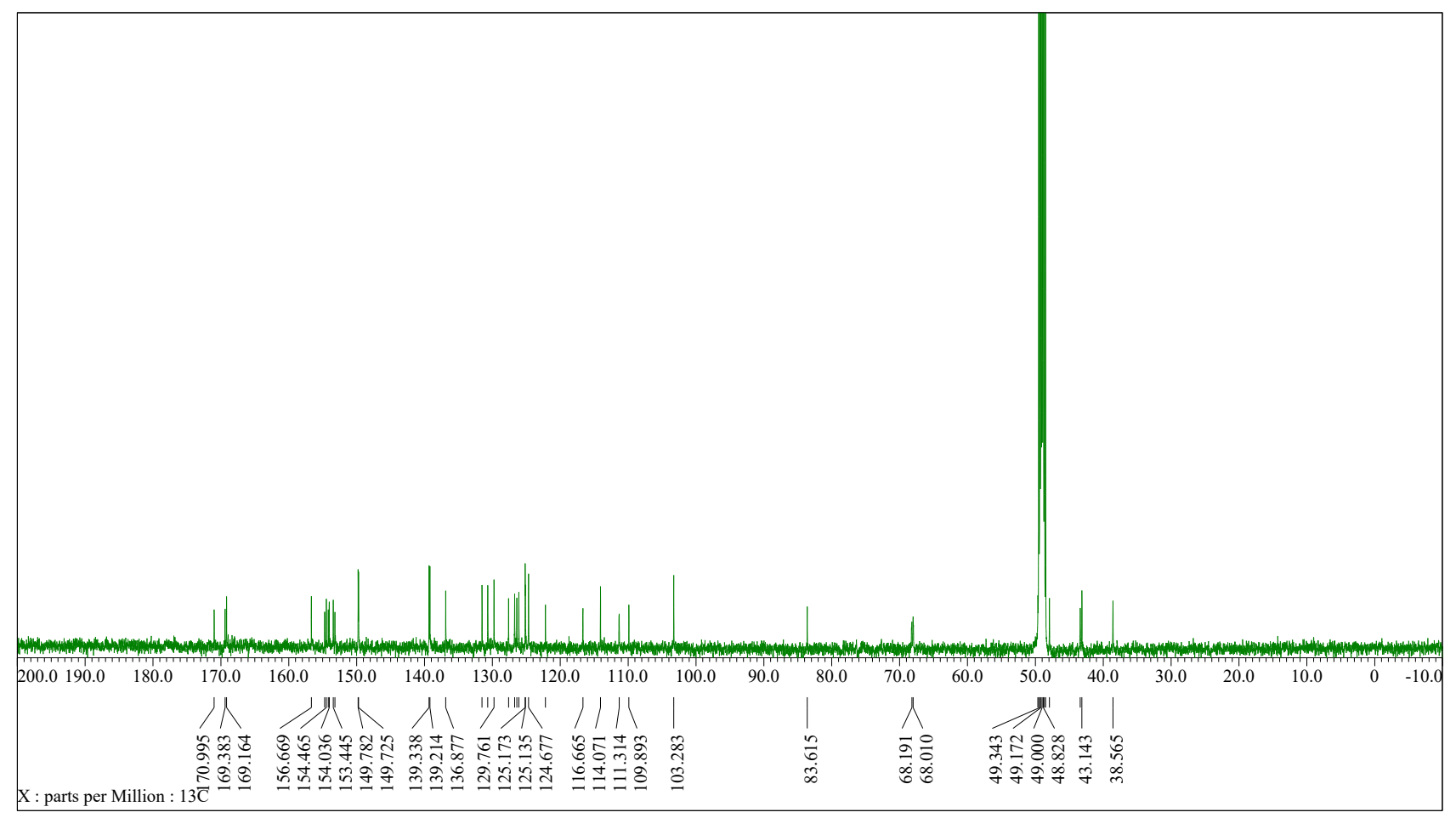


Rhodamine-7 $\left(\mathrm{CDCl}_{3}, 400 \mathrm{MHz}\right)$

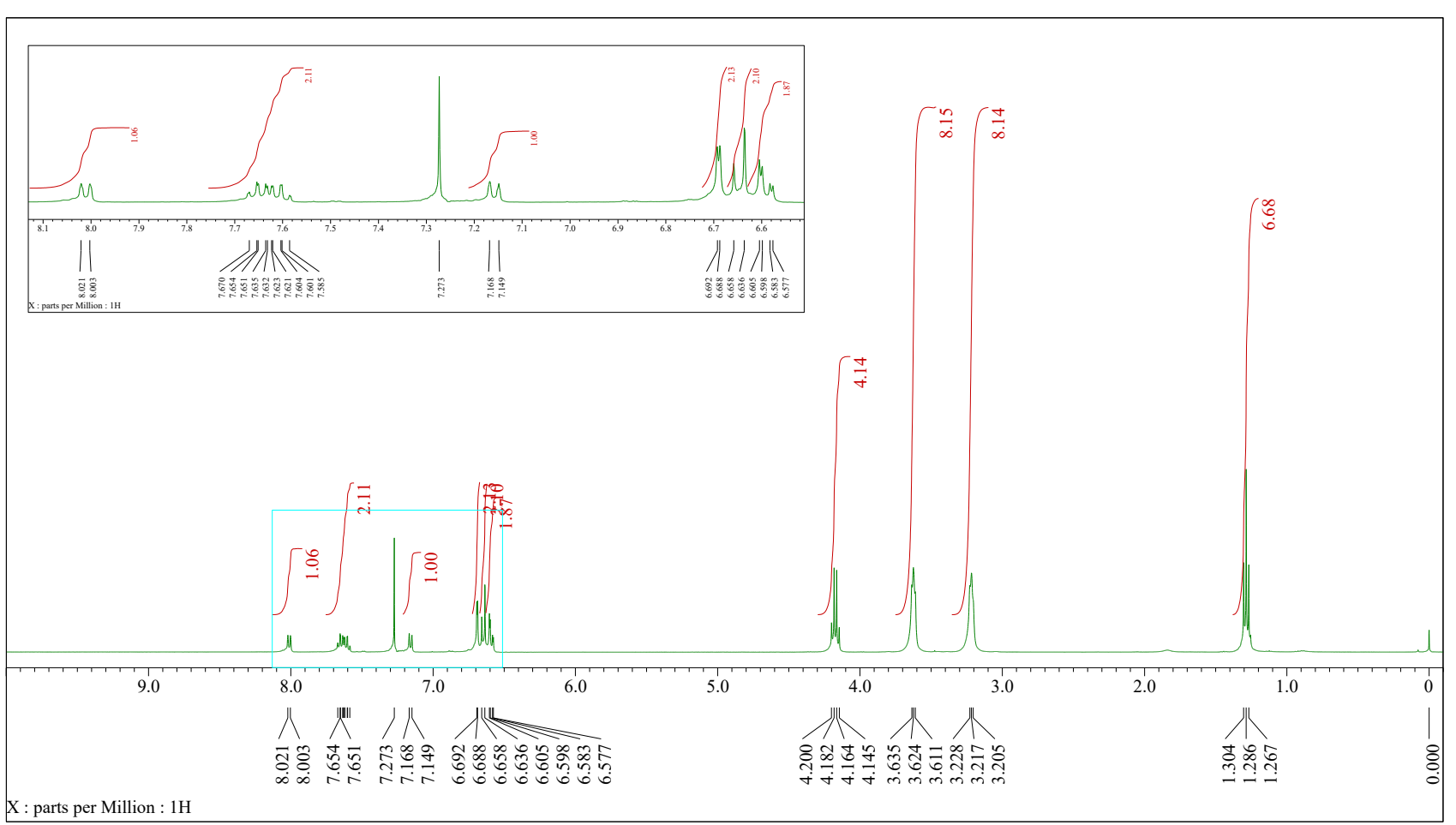

Rhodamine-7 $\left(\mathrm{CDCl}_{3}, 100 \mathrm{MHz}\right)$

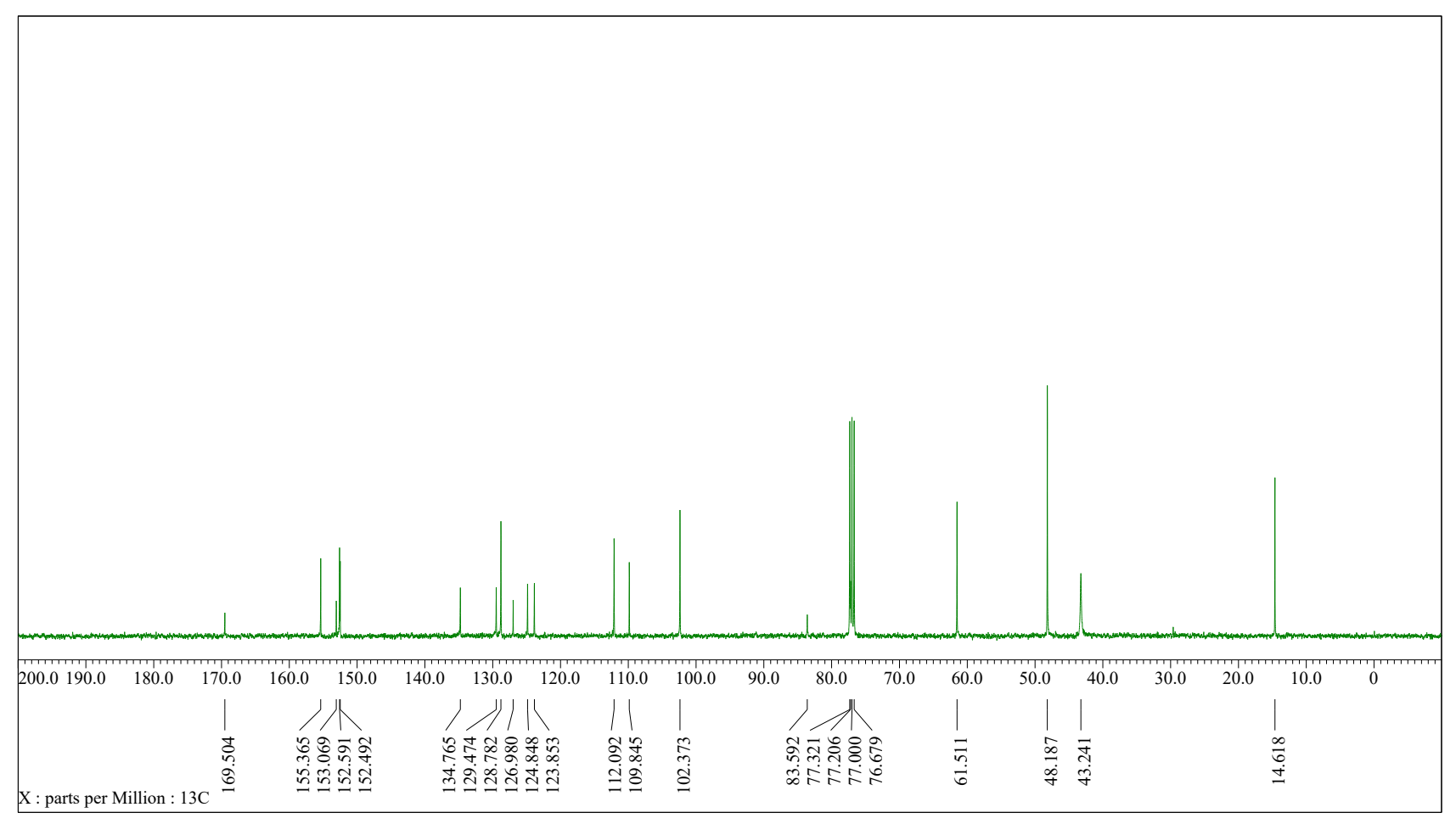


RhoNox-7 ( $\left.\mathrm{CD}_{3} \mathrm{OD}, 500 \mathrm{MHz}\right)$

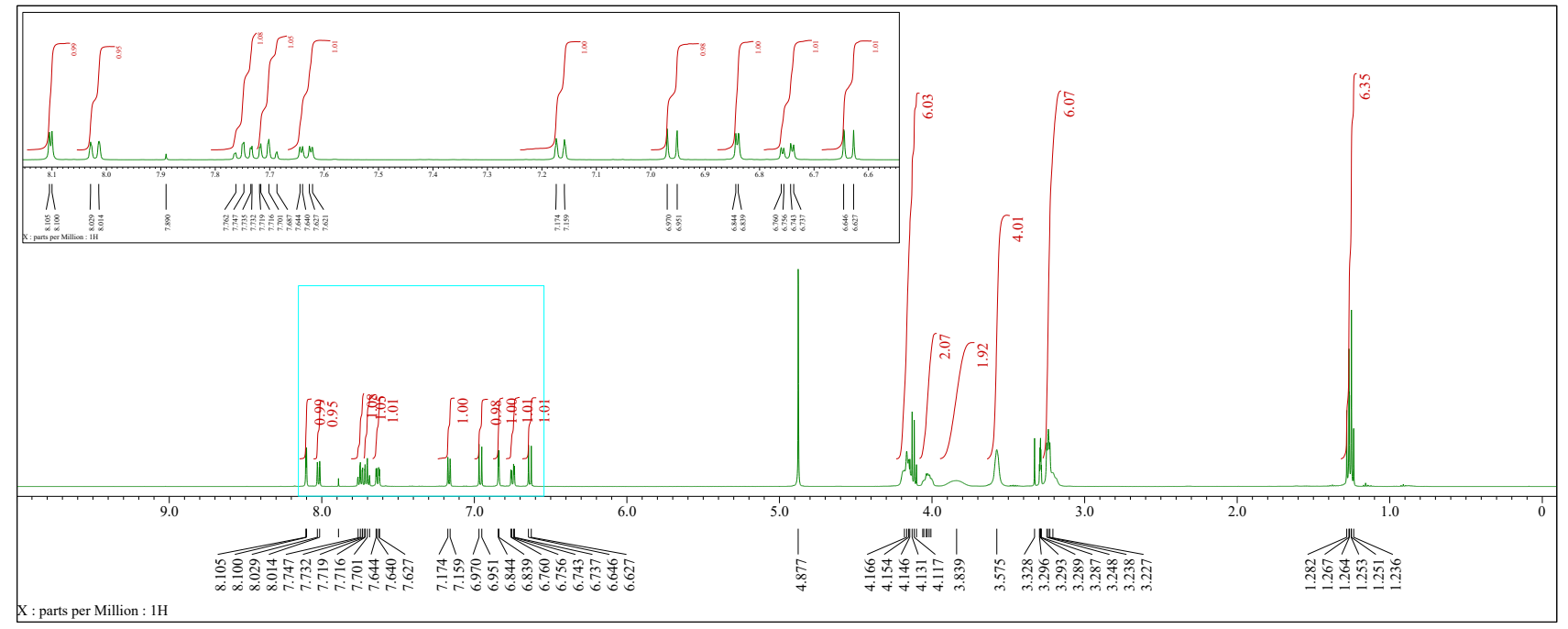

RhoNox-7 ( $\left.\mathrm{CD}_{3} \mathrm{OD}, 125 \mathrm{MHz}\right)$

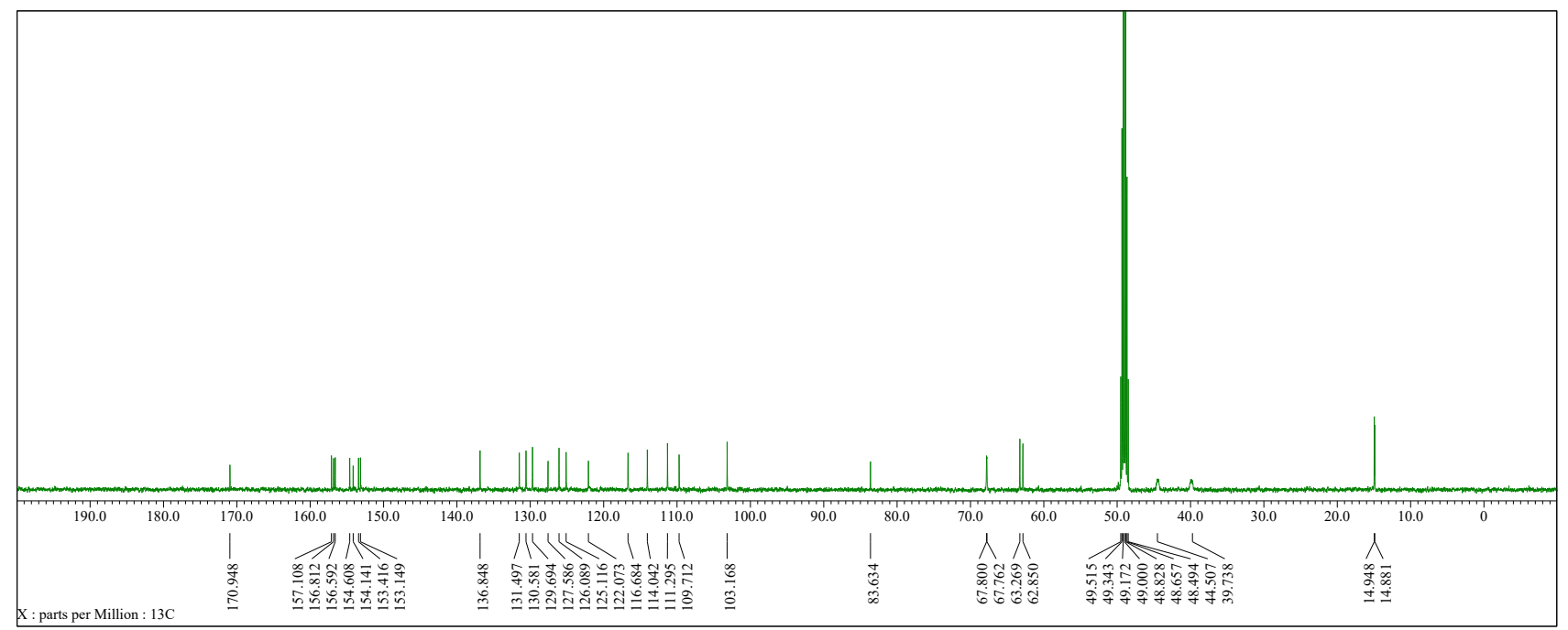

Rhodamine-8 $\left(\mathrm{CDCl}_{3}, 400 \mathrm{MHz}\right)$ 


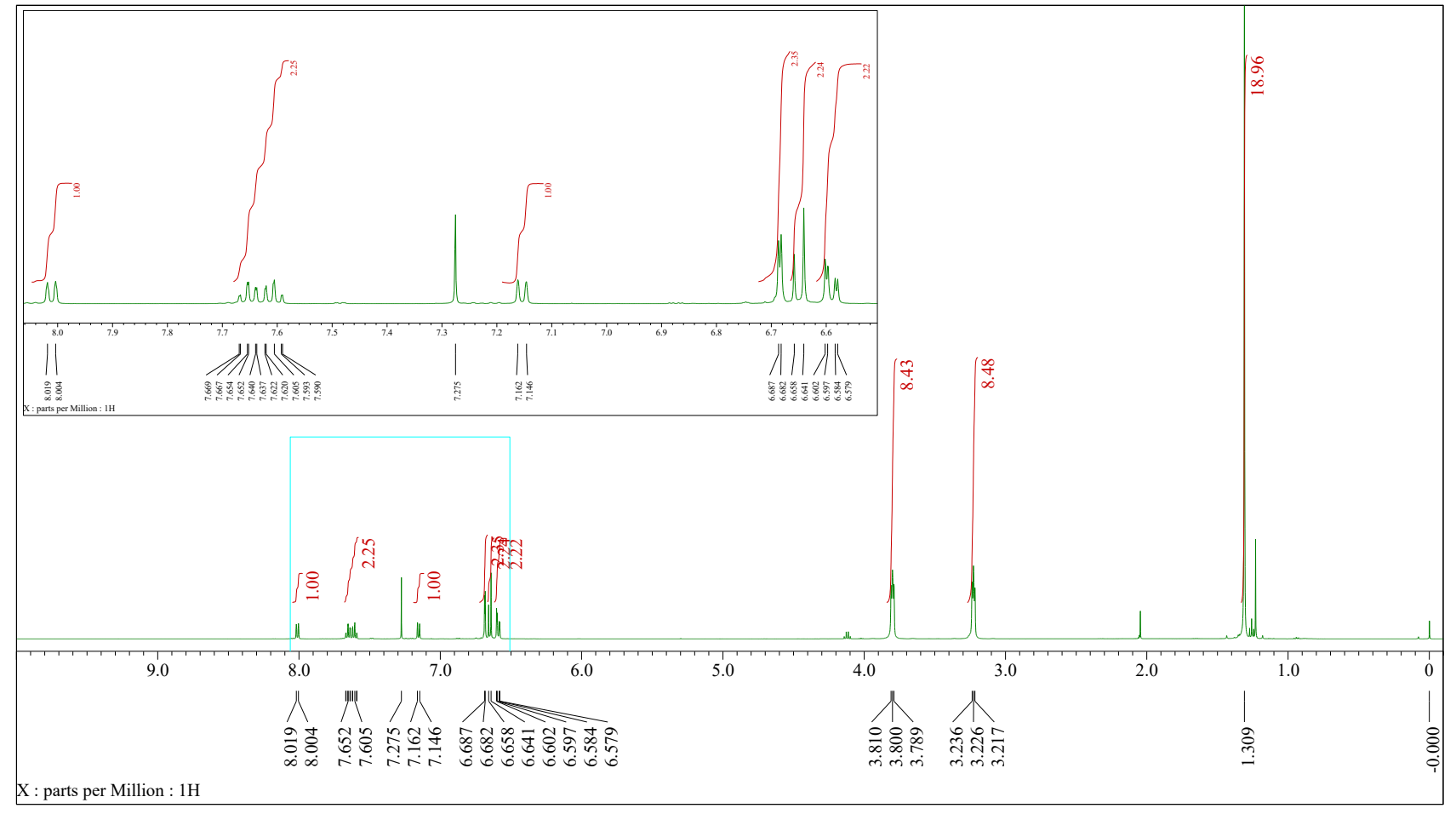

Rhodamine-8 $\left(\mathrm{CDCl}_{3}, 100 \mathrm{MHz}\right)$

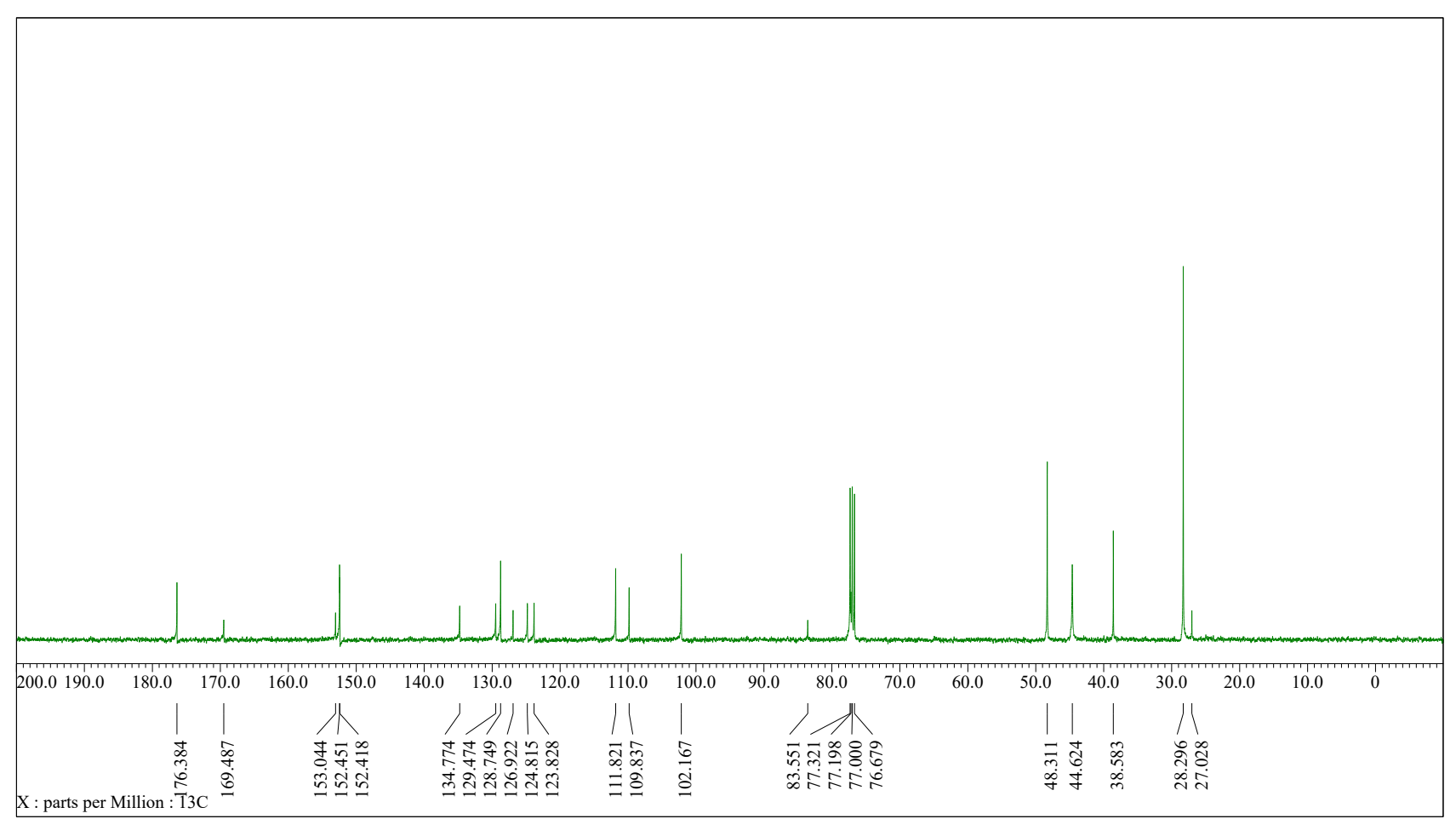


RhoNox-8 $\left(\mathrm{CD}_{3} \mathrm{OD}, 500 \mathrm{MHz}\right)$

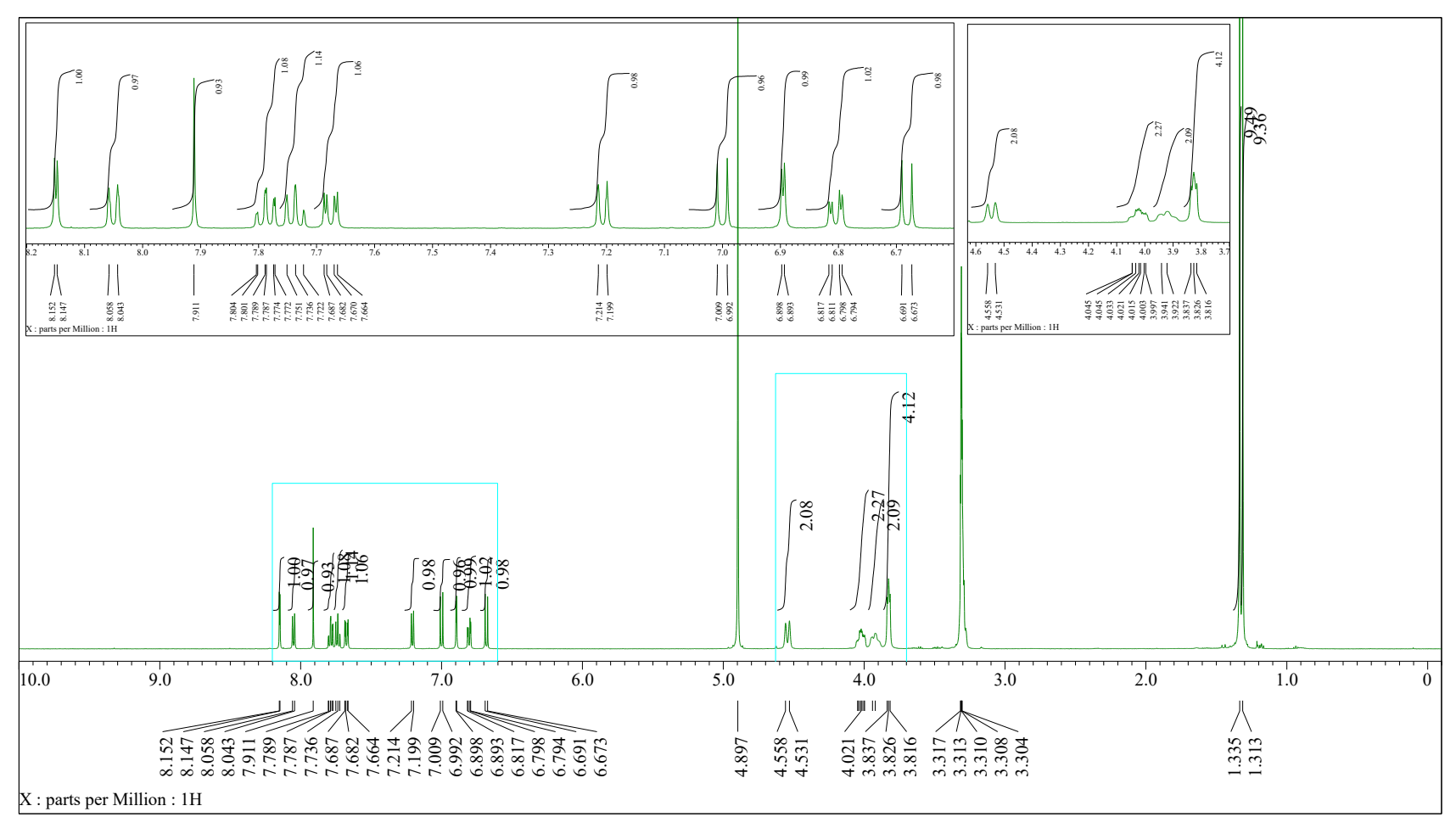

RhoNox-8 $\left(\mathrm{CD}_{3} \mathrm{OD}, 125 \mathrm{MHz}\right)$

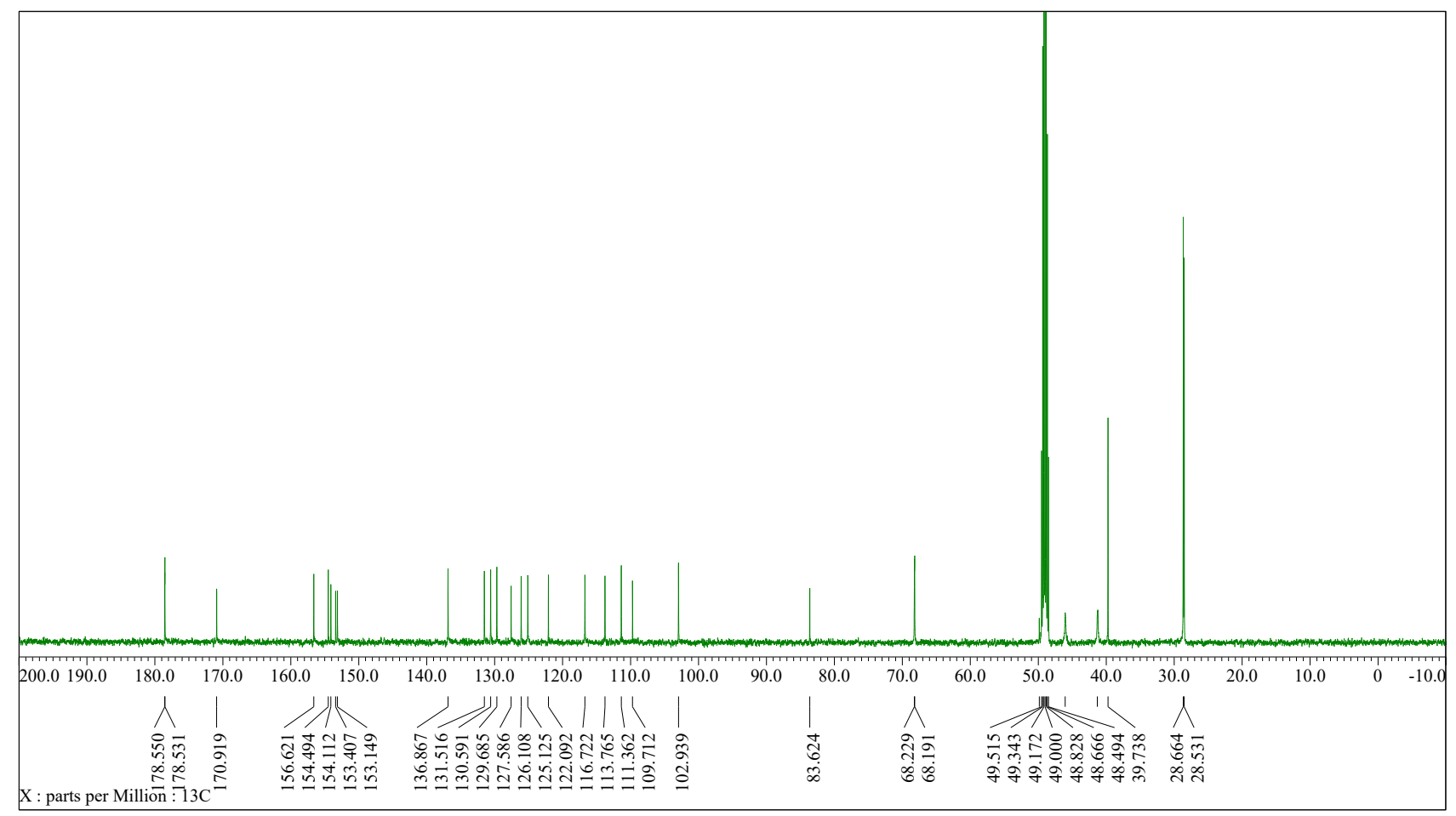

